\title{
WestVirginiaUniversity
}

THE RESEARCH REPOSITORY @ WVU

Graduate Theses, Dissertations, and Problem Reports

2006

\section{Supplemental forages for grazing beef cattle in Appalachia}

\author{
Evans Abenga Basweti \\ West Virginia University
}

Follow this and additional works at: https://researchrepository.wvu.edu/etd

\section{Recommended Citation}

Basweti, Evans Abenga, "Supplemental forages for grazing beef cattle in Appalachia" (2006). Graduate Theses, Dissertations, and Problem Reports. 2429.

https://researchrepository.wvu.edu/etd/2429

This Dissertation is protected by copyright and/or related rights. It has been brought to you by the The Research Repository @ WVU with permission from the rights-holder(s). You are free to use this Dissertation in any way that is permitted by the copyright and related rights legislation that applies to your use. For other uses you must obtain permission from the rights-holder(s) directly, unless additional rights are indicated by a Creative Commons license in the record and/ or on the work itself. This Dissertation has been accepted for inclusion in WVU Graduate Theses, Dissertations, and Problem Reports collection by an authorized administrator of The Research Repository @ WVU.

For more information, please contact researchrepository@mail.wvu.edu. 
Supplemental Forages for Grazing Beef Cattle in Appalachia

\title{
Evans Abenga Basweti
}

Dissertation submitted to the Davis College of Agriculture, Forestry and Consumer Sciences at West Virginia University

\author{
in partial fulfillment of the requirements for the degree of \\ Doctor of Philosophy \\ in
Plant and Soil Sciences
Edward Rayburn, Ph.D. John Balasko, Ph.D.
Gerard D'Souza, Ph.D
Eugene Felton, Ph.D
Plant and Soil Sciences \\ William Bryan, Ph.D., Chair
}

Morgantown, West Virginia

2006

Keywords: sudangrass, pearl millet, triticale, ryegrass, turnip, summer annual, winter annual, naturalized pasture, Pennisetum glaucum (L) R. Br., Sorghum sudanese (P) Stapt. Brassica rapa, Triticale, Lolium multiflorum Lam.,forage accumulation, nitrogen fertilizer, glyphosate, burning, net return. 


\section{Abstract \\ Supplemental Forages for Grazing Beef Cattle in Appalachia}

Evans Abenga Basweti

Pasture productivity in Appalachia is characterized by seasonal variability in growth and availability of forages. Cool-season perennial grasses are the basic source of feed for cow-calf production. Producers require information about incorporating annual forages into grazing systems during months of low productivity of the cool-season species. An experiment was conducted for two years (2004 and 2005) at Reedsville Experimental Farm, West Virginia University, to determine growth rate, herbage accumulation and quality of sudangrass, and pearl millet grown in summer and triticale and a mixture of annual ryegrass and turnips grown in the fall on the same land. Two methods of herbage control, burning and glyphosate, were used to kill existing vegetation before establishing annual forages. Three levels of $N\left(0,50\right.$, and $\left.100 \mathrm{~kg} \mathrm{ha}^{-1}\right)$ were applied to each species. Sudangrass grown in summer produced the most forage mass and was of lower quality compared to pearl millet and naturalized pasture. Pearl millet was more susceptible to competition from other species than sudangrass. Rapid growth of both sudangrass and pearl millet occurred between 30 and 50 days after seeding. Nitrogen application increased forage mass for all forage species grown in summer and fall, and thus, resulted in greater economic return. In addition, $\mathrm{N}$ application hastened physiological maturity of both sudangrass and pearl millet. Forage accumulation from annuals established after glyphosate application was higher than from those established after burning. Use of glyphosate as a method of preplant vegetation control was more profitable than use of burning. Pearl millet established after burning failed to germinate due to competition from naturalized vegetation. In the fall, naturalized pasture and the mixture of annual ryegrass and turnip produced similar forage mass and more than triticale. As expected, the cost of seed and establishment cost for these fall annuals was higher than naturalized pasture. Some establishment costs were recovered when fall established annuals were harvested the following spring. Naturalized pasture that received $100 \mathrm{~kg} \mathrm{~N} \mathrm{ha}^{-1}$ split into two equal portions and applied in summer and fall was ranked the highest in economic returns. A system where sudangrass was grown in summer and triticale in fall produced the highest economic returns when $\mathrm{N}$ was applied at the rate of $200 \mathrm{~kg} \mathrm{ha}^{-1}$ and glyphosate was used as a method of preplant vegetation control. A system with sudangrass after glyphosate in summer and a mixture of annual ryegrass after glyphosate in fall produced the highest DM yields but, high cost of turnip seed lowered the economic ranking. In summer, sudangrass produced more DM than pearl millet, but the high cost of seed and high seed rate lowered its net return. Results of this study suggest that sudangrass can be used to supplement naturalized pasture in summer and triticale and a mixture of annual ryegrass and turnip in fall for both high quality and quantity. For higher productivity and economic returns, fall annuals can be harvested again in spring. 


\section{Acknowledgements}

This study would not have been possible without the contribution of various individuals and institutions whose generous assistance has culminated in its successful completion. I wish to thank the Ministry of Livestock and Fisheries, Nairobi, Kenya, for granting me study leave. I also wish to thank West Virginia University for financial and material support. I would like to thank the following individuals for their support and resourcefulness while undertaking this study. In particular, I wish to thank my advisor and mentor, Dr. William Bryan, for accepting me to work under him and for having a lot of patience and understanding while guiding me, at times under stressful circumstances. In addition, special thanks go to Dr. Edward Rayburn for his help with experimental design, field work and chemical analysis of samples. Further appreciation goes to my other committee members, Drs. John Balasko, Gerard D'Souza and Eugene Felton for their helpful suggestions and guidance as the study progressed. Also, much thanks to Dr. George Seidel for his help with statistical data analysis. I greatly appreciate Drs. James Gekara and Domingo Mata, and Mr. Mark Satterfield for their support with field data collection. I would like to thank graduate students, work study students, and the entire farm crew at the Reedsville Experimental Farm for their help with the project. I also wish to thank my room mates, Kennedy Moindi and Harrison Oonge for their moral support.

Finally, I wish to thank my loving wife, Dr. Elizabeth Abenga and our sons, Elvis and Ernest Abenga for allowing me to be away from them for such a long period of time and their constant support and encouragement. To you all, I wish to say Ahsante sana. 


\section{TABLE OF CONTENTS}

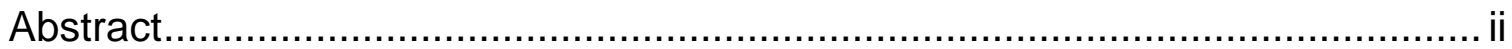

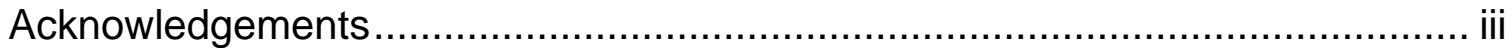

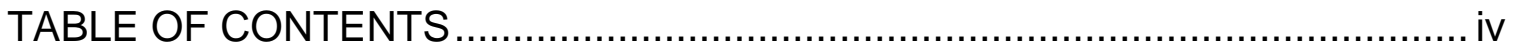

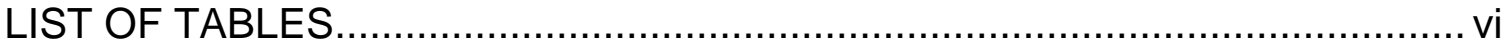

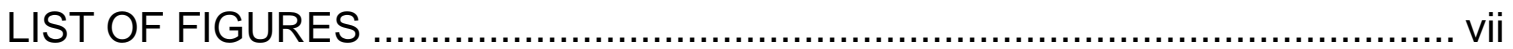

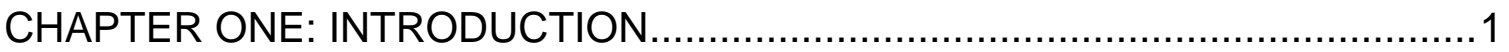

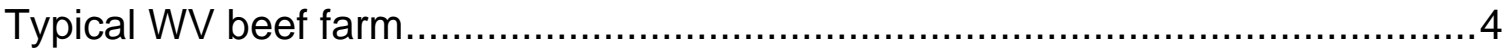

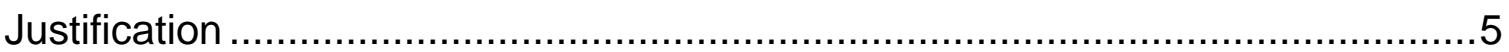

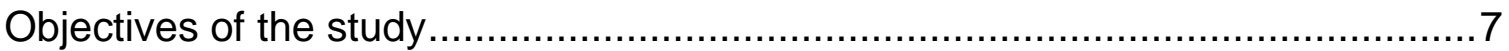

CHAPTER TWO: LITERATURE REVIEW ..........................................

Effect of species and management on DM production................................. 8

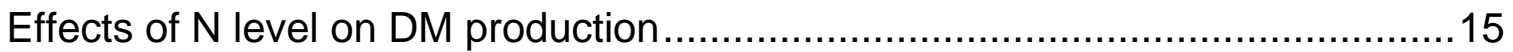

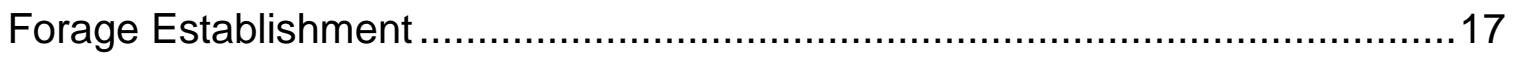

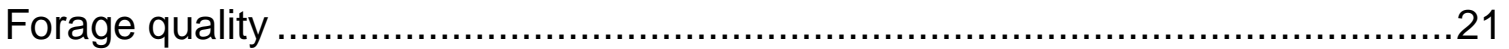

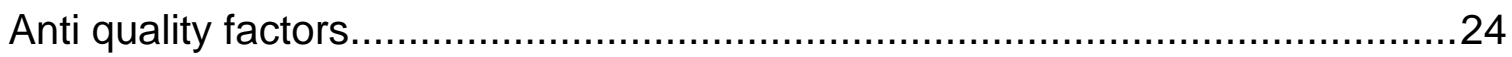

Physiological maturity of warm-season annuals ........................................25

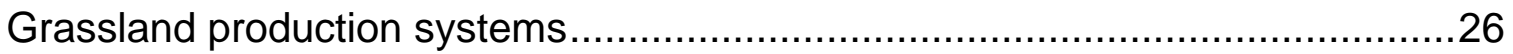

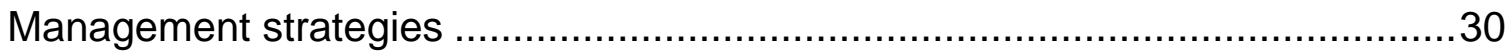

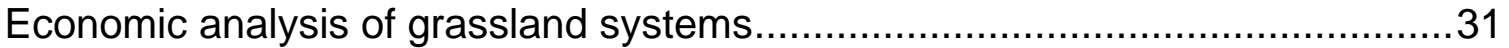

CHAPTER THREE: MATERIALS AND METHODS ......................................33

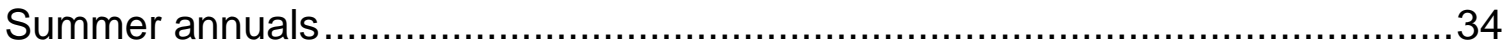


Method of determining morphological stages of sudangrass and pearl millet.....35

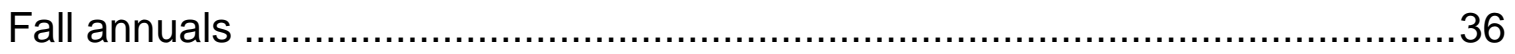

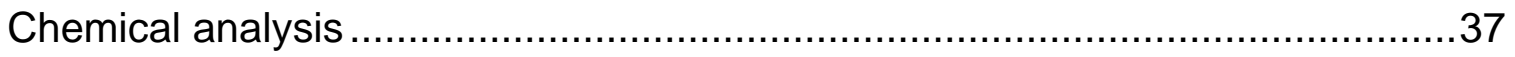

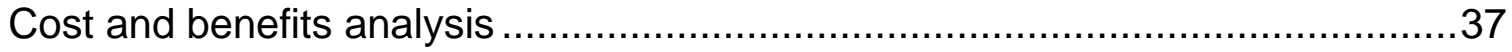

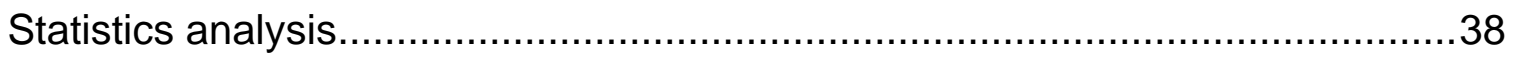

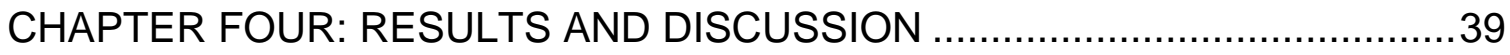

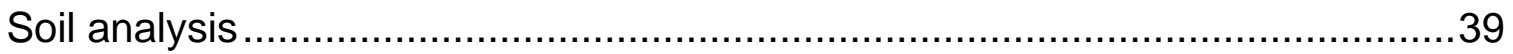

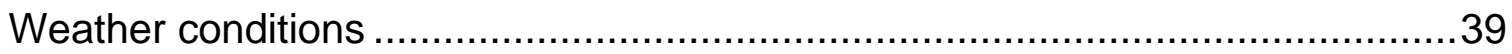

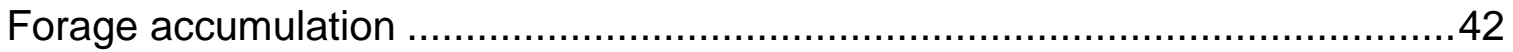

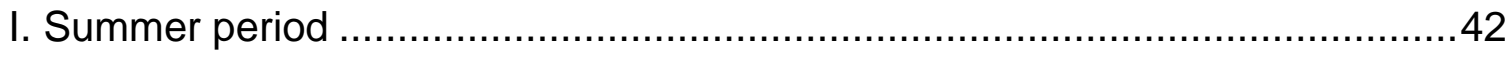

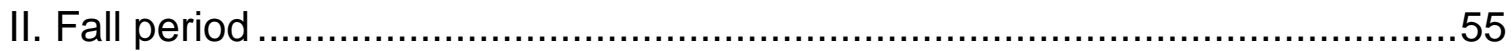

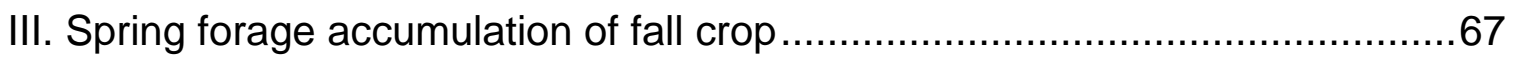

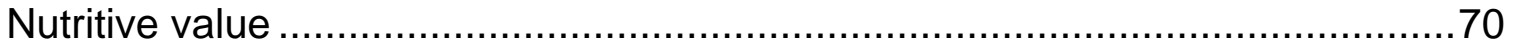

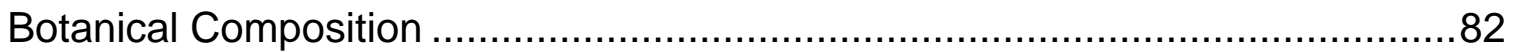

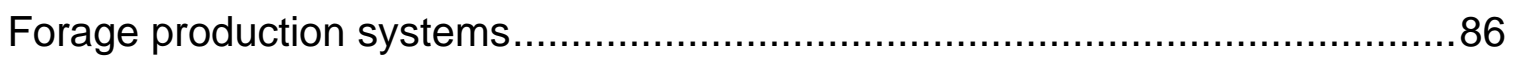

Economic analysis of different forage production systems .............................8

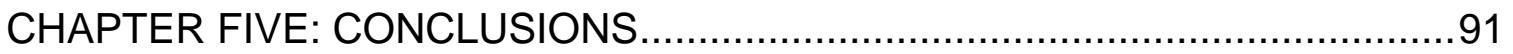

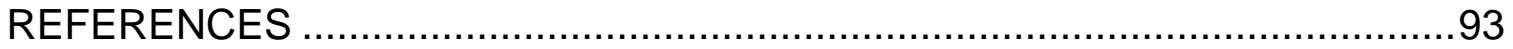

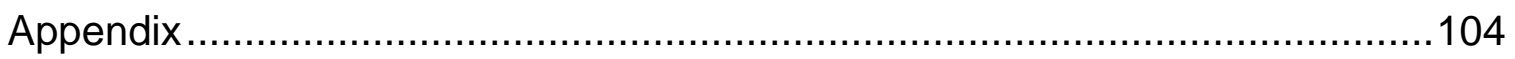




\section{LIST OF TABLES}

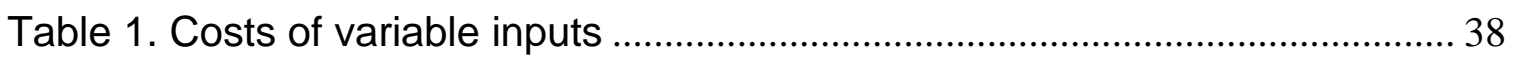

Table 2. The effect of species, $\mathrm{N}$ level and preplant vegetation control on morphological maturity of sudangrass and pearl millet.............................................. 56

Table 3. Crude protein, ADF, NDF and TDN concentrations of pearl millet, sudangrass and naturalized pasture............................................................................ 75

Table 4. Effect of fall species on CP, ADF, NDF and TDN concentrations. ......... 78

Table 5. Effect of method of preplant vegetation control on CP, ADF, NDF and TDN concentrations of sudangrass............................................................................ 78

Table 6. The effect of $\mathrm{N}$ level on $\mathrm{CP}, \mathrm{ADF}, \mathrm{NDF}$ and TDN concentrations of annual forages.

Table 7. The effect of $\mathrm{N}$ level on $\mathrm{CP}, \mathrm{ADF}, \mathrm{NDF}$ and TDN concentrations of fall species.

Table 8. The effect of species,preplant vegetation control, and $\mathrm{N}$ level on botanical composition of summer crops.

Table 9. The effect of species, preplant vegetation control, and $\mathrm{N}$ level on botanical composition of fall crops.

Table 10. Forage accumulation from different production systems.

Table 11. Net return per hectare over variable costs for different production systems. 


\section{LIST OF FIGURES}

Figure 1. Monthly mean air temperature and precipitation, and 30-year mean values for each parameter at Reedsville, WV

Figure 2. Monthly mean maximum and minimum air temperature and 30-year mean values for each parameter at Reedsville, WV

Figure 3. Effect of species on summer forage DM production................................ 43

Figure 4. Growth rate of pearl millet (PM) and sudangrass (SG) 2005 ................ 46

Figure 5. Effect of $\mathrm{N}$ on summer DM production across all species and years .47

Figure 6. Effect of $\mathrm{N}$ level on summer forage DM production of naturalized pasture, pearl millet and sudangrass

Figure 7. Effect of preplant vegetation control, species, and year on DM production of sudangrass (SG) and pearl millet (PM) compared to naturalized pasture (NP). 51

Figure 8. Effect of preplant vegetation control and year on summer DM production

Figure 9. Effect of preplant vegetation control and $\mathrm{N}$ level on summer DM production

Figure 10. Effect of species on fall DM production

Figure 11. Effect of vegetation control on fall DM production of the mixture of annual ryegrass and turnip, and triticale compared to naturalized pasture.

Figure 12. Effect of $\mathrm{N}$ application on fall DM production.

Figure 13. Effect of days after seeding on forage DM accumulation of the mixture of annual ryegrass and turnip, triticale and naturalized pasture during the fall of (a) 2004 and (b) 2005

Figure 14. Effect of preplant method of vegetation control on DM production of turnip in fall.. 65

Figure 15. Effect of $\mathrm{N}$ level and year on DM production of turnip in fall. 66 
Figure 16. The effect of fall species (mixture of annual ryegrass and turnip, triticale and naturalized pasture) harvested in spring (5/4/06) on forage accumulation

Figure 17. The effect of method of preplant vegetation control on forage accumulation of the fall planted crop harvested in spring.

Figure 18. The effect of level of $\mathrm{N}$ on forage accumulation of fall planted crops that were harvested in spring.

Figure 19. Effect of summer species and year on TDN concentrations.

Figure 20. Effect of summer species and year on ADF and NDF concentrations

Figure 21. Effect of fall species and year on ADF and NDF concentrations. ....... 76

Figure 22. Effect of vegetation control and year on CP and TDN concentrations 


\section{CHAPTER ONE: INTRODUCTION}

Appalachia is a region that stretches along the Appalachian Mountains from southern New York to Northern Mississippi. The region includes 406 counties including all of West Virginia, with beef production as a major agricultural activity. Beef production is mainly pasture based due to the region's mountainous terrain which limits arable farming. In West Virginia, beef is raised mainly in cow-calf production systems (West Virginia Agriculture Statistics, 1997). Other systems, such as stocker and finisher, are practiced to a lesser extent. A production system is determined by the quantity and quality of available forage, individual animal potential, supplemental feeds required, and wishes of the producer (Chessmore, 1979). Naturalized grassland, mainly Kentucky bluegrass (Poa pratensis L.), orchardgrass (Dactylis glomerata L.), tall fescue (Festuca arundinacea Schreb), and white clover (Trifolium repens L.), is the major feed resource. Forage availability and quality are highly variable throughout the year. Uneven seasonal distribution of forage growth is brought about by changes in the weather. Summer and winter annuals may reduce seasonal variation in available forage, with the possibility of increasing animal output per unit area and allowing farmers more flexibility. However, production costs may increase with use of such annuals. Little is known about the profitability of introducing annual forages into Appalachian pasture-based beef production systems. 
Although cool-season perennial forages are the predominant species used in Appalachia, annual forages have the potential to produce large quantities of biomass within a short period. Creamer and Baldwin (2000) reported that a sorghum sudangrass hybrid, pearl millet [Pennisetum glaucum (L.) R. Br.], and sudangrass (Sorghum sudanense (P) Stapt.) produced 8.8, 6.7 and, 5.6 tons/ha, respectively. High biomass production of summer annuals can be attributed to fast growth rates and heat resistance. In other reports (Fontaneli et al., 2001) pearl millet and sorghum sudangrass produced yields ranging from 5.6 to 7.8 tons/ha and crude protein concentrations from 14.4 to $19.9 \%$.

Cool-season grasses start growing in late March, growth rate increases rapidly in May and decline rapidly in June. Bryan and Mills (1988) reported that more than $75 \%$ of forage accumulation occurred between April and June in Morgantown, WV. Forage (cool-season) growth rate is low in July and August because of high ambient temperatures and low precipitation. The declining amount of forage available to animals in July and August coincides with increasing feed requirements of spring born calves. Introduction of summer annual grasses is aimed at providing needed forage during this period of deficit.

Some potential winter annuals that can be used for deferred grazing (Chessmore, 1979) are annual ryegrass, cereal rye, triticale, vetch, field peas, and brassicas. These species can withstand cooler temperatures, are fast growing and have the potential to offset the declining herbage production of perennial forages in November and December (Reid et al., 1994; Wiedenhoeft, 1993; Medal, 1986). Medal (1986) evaluated winter annual forages at 
Morgantown and Reedsville and found that rye provided more ground cover than field pea and hairy vetch. He further reported that the yield of rye decreased as seeding date was delayed from August to October. Studies in Florida and Missouri have shown that winter annual forages offer quality feed for calves retained until spring (Coffey et al., 2002 and Kallenbach et al. 2003). In another study, Arthington and Kalmbacher (2003) reported that spring calves weaned early and fed on winter rye (Secale cereale L.) had greater average daily gain in the first year compared to calves that remained with their dams on bahiagrass (Paspalum notatum) and were weaned at the normal age of 6 months. Annual ryegrass (Lolium multiflorum Lam.) is a popular component of pasture systems in the southeastern US because it is easy to establish, has high forage quality and is adapted to a wide range of soil types. According to Evers et al. (1997), annual ryegrass can support a stocking rate of up to $700 \mathrm{~kg} \mathrm{ha}^{-1}$ in winter depending on management and climate.

Tall fescue, a native cool-season forage, can be used to extend the grazing period. Tall fescue is among the most frost tolerant perennial grasses (Chessmore, 1979). Studies have shown that fertilized tall fescue can provide good nutrition for beef cattle during winter (Hypes, 1993). In late fall, stockpiled tall fescue can be high in protein, sugars, and digestible energy, providing good forage in early winter (Hypes, 1993). However, quality declines as the winter progresses.

Brassica species are used to extend the grazing period, are fast growing, and continue to grow during fall. In addition, they tolerate low temperatures, 
maintain quality with advancing maturity and establish rapidly (Reid et al., 1994). A forage brassica crop can provide adequate herbage from summer months well into winter thereby reducing the need for purchased feeds (Wiedenhoeft, 1993). Published reports about the suitability of both warm- and cool-season annual forages for summer and winter on the same land in the Appalachian region are lacking.

\section{Typical WV beef farm}

A typical West Virginia farm consists of land suitable for cultivation, pastureland, and woodland. According to WV Agricultural Statistics (1997) the average $\mathrm{WV}$ farm is 80 ha. Of this land, 10 ha are used for hay production, and 26 ha for grazing. Total hay production from 10 ha at an annual accumulation rate of $6250 \mathrm{~kg} \mathrm{ha}^{-1}$ is $62,500 \mathrm{~kg}$. One animal unit consumes an average of 1770 kg DM during a winter of 150 days. Thus, 10 ha of hay can support 35 cows during the winter period. The stocking rate is 3.5 animal units ha ${ }^{-1}$ in winter while the stocking rate of grazing land is 1.3 animal units ha ${ }^{-1}$ (one animal unit is defined as a cow weighing $450 \mathrm{~kg}$ ). Cows are bred in May/June and they calve in March/April. The animals are rotationally grazed on naturalized pastures. Calves are weaned in late September and sold. The farmer starts feeding hay in mid November and stops in mid to late April.

Let it be assumed that $20 \%$ of the hayland will be used for annual forages. This means that the total area for hay production will be reduced by 2 ha ( $20 \%$ of $10 \mathrm{ha})$. Annual production from warm-season annuals as reported in the literature is expected to be $7,500 \mathrm{~kg} \mathrm{DM} \mathrm{ha}^{-1}$ and that from cool-season annuals 
$4,400 \mathrm{~kg} \mathrm{DM} \mathrm{ha}^{-1}$ giving a total production of $11,900 \mathrm{~kg} \mathrm{DM} \mathrm{ha}^{-1}$ if cool-season annuals follow warm-season on the same land. Herbage accumulation of annual forages from 2 ha is $23,800 \mathrm{~kg} \mathrm{DM} \mathrm{y}^{-1}$, equivalent to production from 4 ha of hay. Overall, using 2 ha hayland for annuals reduces the area available for hay production but, because DM production is doubled by using annual crops the equivalent area of hay is $12 \mathrm{ha}$. Therefore, introducing annual forages to this typical farm allows an increase in herd size to 41 (a 17\% increase). However, additional costs of annual seeding and grazing management will be incurred.

\section{Justification}

Beef production is the major agricultural enterprise in Appalachia. The main system of production is cow/calf that utilizes cool-season perennial grassland as the main feed resource. Growth rate of cool-season perennials declines during summer (July/August) and winter (November/March) because of high and low ambient temperatures, respectively, that do not favor the growth of these forages. During winter, farmers depend on either hay or stockpiled forage. A pregnant and lactating cow of $450 \mathrm{~kg}$ liveweight requires $1770 \mathrm{~kg}$ of forage to complete the winter period. Hay varies in quality and sometime is not adequate to meet nutritional requirements of animals. In addition, hay making and storage is expensive. Summer and winter annual forages could be incorporated into production systems to supplement perennial forages in summer and extend the grazing season in winter. Studies are required to determine how much forage can be produced from summer and winter annuals in an Appalachian production system. Traditionally, producers rely on perennial forages and have not tried 
annuals. Therefore, there is opportunity to develop beef production systems incorporating annuals. Producers also need to know how to establish and manage annuals within the constraints of their system. They need to know herbage accumulation potential and quality of different annual species in relation to methods of establishment, fertilizer application, and utilization.

Most farmers keep an inadequate accounting of inputs and outputs for the component enterprises of their livestock production systems. They do not know how different components in a pasture based production system contribute to overall profitability. Detailed information about the components is needed to understand costs and benefits of the whole system. There is, therefore, a need to develop and compare different pasture based production systems and determine their profitability for beef production.

This study examined the use of warm-season and cool-season annual forages to meet the feed demand of an Appalachian cow/calf production system in summer and winter. The study analyzed costs and benefits of supplementing naturalized forage with annual forages. 


\section{Objectives of the study}

This study is part of an Appalachian Beef Project with an overall goal of finishing beef on pasture to add value to small hill land farm production. The study had the following objectives:

1. To compare growth, quality, and DM accumulation of sudangrass and pearl millet grown in summer followed by triticale and a mixture of annual ryegrass and turnip grown in fall with naturalized pasture.

2. To compare burning and glyphosate application for preplant vegetation control.

3. To determine effects of $\mathrm{N}$ on herbage quantity and quality

4. To determine the effect of nitrogen application on physiological maturity of sudangrass and pearl millet.

5. To determine the economic costs and benefits of warm-and cool-season forages grown on the same land.

6. To develop and compare different systems of forage production. 


\section{CHAPTER TWO: LITERATURE REVIEW}

Forages can be categorized into warm-season and cool-season groups based on their adaptation to environmental temperatures. Warm-season forages

grow well at temperatures ranging between $15{ }^{\circ} \mathrm{C}$ and $35{ }^{\circ} \mathrm{C}$ with moderate soil moisture stress, whereas cool-season forages grow well at cool temperatures ranging between $5{ }^{\circ} \mathrm{C}$ and $23{ }^{\circ} \mathrm{C}$. Yield of both cool- and warm-season forages is affected by various factors including; species, level of $\mathrm{N}$ application, and other management and environmental factors.

\section{Effect of species and management on DM production}

Warm-season annuals include two species that are outstanding performers for summer niches (Snapp et al., 2005). They are sudangrass and pearl millet. Sudangrass and pearl millet are erect forages which grow to a height of 1.0 to $2.4 \mathrm{~m}$ (Ball et al., 1996). Both crops can thrive in a wide range of elevation and latitude with optimum growth obtained at a mean temperature of 27 ${ }^{0} \mathrm{C}$ and an average annual precipitation of over $500 \mathrm{~mm}$ (Jung and Reid, 1966). These forages have superior ability to fix $\mathrm{CO}_{2}$ at higher temperatures compared to cool-season forages (Vickery, 1981). At higher temperatures the rate of photosynthesis per unit leaf area of warm-season grasses is double that of coolseason grasses.

Production of DM of different warm-season annual species has been investigated. In a study by McLaughlin et al. (2004), DM yield and nutrient uptake of five warm-season annual grasses was compared to that of bermudagrass [Cynodon dactylon (L.) Pers.] over a three-year period. These 
annuals were browntop millet [Panicum ramosum (L.) Stapf.), pearl millet, sorghum-sudangrass [Sorghum bicolor (L.) Moench] and crabgrass [Digitaria sanguinalis (L.) Scop.]. During the study period, they reported that sorghumsudangrass and pearl millet were higher in DM yield and P uptake than the other annuals but were equal to established bermudagrass.

Fontaneli et al. (2001) investigated the effects of seeding date and cultivar on DM yield, yield distribution, and nutritive value of pearl millet and sorghumsudangrass in Florida. They had four seeding dates in 1996 starting on May 10 and six in 1997 starting on March 20. Seeding dates were 3 wk apart. Three millet ('GK 600', 'Millex 32', and 'Tifleaf 2') and two sorghum hybrid ('Hygrazer' and 'SX 15') cultivars were tested. Total DM yield, averaged across cultivars, decreased from 7.4 to $5.6 \mathrm{Mg} \mathrm{ha}^{-1}$ from the first to the fourth seeding date in 1996 and from 7.4 to $4.4 \mathrm{Mg} \mathrm{ha}^{-1}$ from the first to the sixth seeding date in 1997. Leaf percentage generally was above $70 \%$ and was greatest for Tifleaf 2 . They concluded that seasonal distribution of DM was affected by planting date but not by cultivar. They also suggested that seeding on two dates approximately 3 to 6 week apart was a good strategy for improving yield distribution of these cultivars and providing high nutritive value forage for nearly 5 months.

The frequency of harvest can have a profound effect on herbage accumulation of both sudangrass and pearl millet. Burger and Hittle (1967) investigated the effect of harvest frequency and stubble height on yield of sudangrass and pearl millet in Illinois. They concluded that three clippings gave more yield than four clippings, and a low stubble height of $7.6 \mathrm{~cm}$ produced more 
than a high stubble height of $15.2 \mathrm{~cm}$. Similarly, Holt and Alston (1968) concluded that the best forage yield is obtained with less frequent harvests and shorter stubble heights. In contrast, Jung and Reid (1966) reported that more frequent cutting increased forage production by increasing the number of tillers. According to Lopez-Dominguez et al. (2001), forage yield and quality are consistently associated with plant height, number of tillers, internode number, and stem diameter. The optimum nutrient content depends on soil moisture level, fertilization, and planting date.

Stubble height can have an influence on the amount of herbage accumulation. Clapp and Chamblee (1970) investigated the influence of different defoliation systems on the regrowth of pearl millet and sudangrass varieties. They compared stubble heights of $8,10,15$, and $25 \mathrm{~cm}$. They reported a marked reduction in yield when these warm-season forages were defoliated to $8 \mathrm{~cm}$ as compared to $25 \mathrm{~cm}$ for 21 out of 24 harvests. Net gain in yields ranged from 1,203 to $2,039 \mathrm{~kg} \mathrm{ha}^{-1}$ within a 30 -day growth period by raising stubble height from $8 \mathrm{~cm}$ to $25 \mathrm{~cm}$ at a single harvest. They concluded that DM production was influenced more by variation in stubble height at the second harvest than when these same variations were imposed at the first or third harvest. Hart et al. (1971) examined the effect of post-seeding management on establishment and yield of a sudangrass hybrid. They reported that stubble height had no significant effect on yield in the first year of their two-year study period. Cutting to a $10-\mathrm{cm}$ stubble gave higher sudax yields than cutting to $20-\mathrm{cm}$ stubble in the second year of their study. Broyles and Fribourg (1959) investigated cutting 
management of sudangrass and pearl millet. They concluded that cutting at early bloom to $10 \mathrm{~cm}$ stubble produced largest yield. They also reported that Gahi-1 pearl millet produced more forage mass compared to sudangrass.

Worker (1973) determined the effect of row spacing and stage of maturity at harvest on DM production of sudangrass, sorghum-sudangrass, and a sudangrass hybrid under dry condition in California. He reported that DM production decreased as row spacing was increased from 35.6 to $88.9 \mathrm{~cm}$. Total DM production was highest with harvest at the flowering stage and it averaged $27,600 \mathrm{~kg} \mathrm{ha}^{-1}$. In contrast, Hart and Burton (1965) reported higher yield of pearl millet planted at row spacing of $60 \mathrm{~cm}$ and $90 \mathrm{~cm}$ than millet planted at $17.5 \mathrm{~cm}$ in Georgia in a season with normal rainfall. In a season with above normal spring rainfall, yield was higher at the narrower row spacing and the same in a very dry season.

Cool-season grasses are bimodal in seasonal distribution of growth (Balasko and Nelson, 2003; Brock and Hay, 1993; Bryan and Mills, 1988). Peak forage accumulation is in May for spring and September for fall. During July and August high temperatures and drought limit the growth of cool-season forages (Bryan and Mills, 1988). Bryan et al. (2000) investigated the productivity of Kentucky bluegrass pasture grazed at three heights and two intensities and reported that average herbage mass before grazing ranged from 1,855 to 2,350 $\mathrm{kg} \mathrm{DM} \mathrm{ha}^{-1}$ and after grazing varied from 855 to $1,060 \mathrm{~kg} \mathrm{DM} \mathrm{ha}^{-1}$. They further found that twice as much herbage was produced in a wetter compared to a drier 
year. Rayburn (1977) reported that the winter yield of tall fescue decreased with later dates of stockpiling and fertilization.

Studies investigating yield in cool-season annual forages have been reported. Balasko et al. (1995) and Evers et al. (1997) reported that annual forages that are suitable for winter feeding include annual ryegrass, triticale, and brassicas. Annual ryegrass is of high quality and can withstand the winter period and maintain acceptable quality (Kallenbach et al, 2003). Growth of ryegrass is optimum at temperatures between $20{ }^{\circ} \mathrm{C}$ and $23{ }^{\circ} \mathrm{C}$, and drops markedly below $10^{\circ} \mathrm{C}$ (Vickery, 1981). It has been reported that ryegrass competes well with weeds (Griffith and Chastain, 1997). Smith and Collins (2003) listed several attributes of brassicas including tolerance to frost, maintenance of forage quality, and some have massive roots that function as a storage organ for nonstructural carbohydrates thus providing quick regeneration in spring. In addition, they germinate rapidly and establish easily.

Cool-season annual forages have different growth patterns and accumulations. Redfearn et al. (2002) evaluated differences in cumulative forage yield and distribution among three cultivars of annual ryegrass. Plots were harvested six times beginning in December at a 30-day interval during the 19971998 and 1998-1999 growing seasons. They reported that there were no differences in cumulative yield for the three cultivars.

Weinert et al. (2002) reported that an accumulation of 3,000 to $4,600 \mathrm{~kg}$ $\mathrm{ha}^{-1}$ was obtained from cereals and brassicas sown in fall as cover crops. Forage brassica crops could provide adequate herbage accumulation during the 
late summer months and well into early winter months, thereby reducing the need for purchased feeds (Wiedenhoeft, 1993). Guillard et al. (1988) indicated that Tyfon, a brassica hybrid, produced greater yields than stockpiled pastures, and produced high yields under cool conditions and relatively short days.

Jung and Shaffer (1995) determined the influence of planting and harvest date on productivity of four brassica cultivars in late fall. Turnip and a spinach $x$ mustard hybrid were seeded using a factorial treatment arrangement in a split plot design, with planting date as a whole plot and cultivar as a subplot. Three to six harvest dates were used depending on the planting date. They reported a mean yield of $11,500 \mathrm{~kg} \mathrm{DM} \mathrm{ha}^{-1}$ for all cultivars with optimal planting dateharvest date combination. Total yields were high for crops planted in July and harvested in late October or early November. In an earlier 3-year study, Jung and Shaffer (1993) reported that total yield of turnip planted in June ranged from 3,500 to $8,300 \mathrm{~kg} \mathrm{ha}^{-1}$ and of those planted in August ranged from 3,600 to 6,400 $\mathrm{kg} \mathrm{ha}^{-1}$. They attributed the differences in turnip yields in late autumn to the amount and time of summer precipitation, resistance to foliar diseases, cold tolerance, and the rate of leaf senescence. Delay in planting from late September to late October reduced dry matter production of triticale in lowa, and triticale planted in mid September accumulated 37\% more $\mathrm{N}$ than that planted in mid-October (Schwarte et al., 2005). Their results suggested that triticale should be planted in September to maximize spring forage yield and $\mathrm{N}$ accumulation.

Bruckner and Raymer (1990) conducted forage yield trials in Georgia. They evaluated twelve small-grain cultivars in clipping trials at four locations for 
three years. Small-grain species were wheat (Triticum aestivum L.), oat (Avena sativa L.), rye and triticale ( $X$ Triticosecale Wittmack). They reported that mean forage yields did not vary among species but the distribution varied with rye producing $14 \%$ more forage than wheat, $48 \%$ more than triticale and $234 \%$ more than oat during mid-season (January-February). Monks et al. (1997) investigated winter cover crops in northern and southern West Virginia and reported that rye was the most reliable and winter-hardy cover crop compared to vetch and Austrian winter pea, regardless of location.

Maloney et al. (1999) determined the potential for fall sown spring and winter small grain forages to be used as a source of fall or spring feed in Wisconsin. The small grains were sown alone or in spring-winter grain mixtures in August and harvested in October. Monoculture spring grains were six cultivars of oat, two cultivars of barley (Hordeum vulgare L.), spring triticale, winter triticale, winter rye and two cultivars of wheat and mixtures consisted of winter rye and winter wheat or winter triticale in combination with either oat or barley or spring triticale. They reported that monoculture spring grains (oat, barley, and spring triticale) averaged $4,250 \mathrm{~kg} \mathrm{ha}^{-1}$ fall forage yield, which was more than four times greater than the average $1000 \mathrm{~kg} \mathrm{ha}^{-1}$ fall forage of monoculture winter grain. Mixtures of spring and winter grain averaged $10 \%$ to $20 \%$ less fall forage than spring grain treatment. They attributed differences in yield performance between winter and spring grain to differences in growth characteristic; spring grains would obtain plant heights of $50 \mathrm{~cm}$ or more while winter grains seldom grew above $25 \mathrm{~cm}$. 


\section{Effects of $\mathrm{N}$ level on DM production}

Forages require $\mathrm{N}$ in large amounts (Voet and Voet, 1995). Besides $\mathrm{C}, \mathrm{H}$ and $\mathrm{O} ; \mathrm{N}$ and $\mathrm{K}$ are the most abundant elements in plant material. Forage yield increases substantially with increasing rate of $\mathrm{N}$ application. The actual forage yield response to $\mathrm{N}$ application depends on rate of $\mathrm{N}$ (Jung and Reid, 1966), species, variety (Harms and Tucker, 1973), stage of crop at application (Rozas et al, 2004) and previous management of the field (Bryan, 1985; Monks et al., 1997).

Jung and Reid (1966) investigated the effect of $\mathrm{N}$ fertilization on sudangrass yield at five locations in West Virginia. They applied urea at rates of $0,57,114$, and $227 \mathrm{~kg} \mathrm{~N} \mathrm{ha}^{-1}$. They reported average yield increases of $22 \%$ for $57 \mathrm{~kg} \mathrm{~N} \mathrm{ha}^{-1} ; 35 \%$ for $114 \mathrm{~kg} \mathrm{~N} \mathrm{ha}^{-1}$ and $47 \%$ for $227 \mathrm{~kg} \mathrm{~N}^{-1}$ over yield of unfertilized grass. Sumner et al. (1965) reported that $\mathrm{N}$ applied at the rate of 227 $\mathrm{kg} \mathrm{ha}^{-1}$ was optimum in relation to DM production, and higher rates of $\mathrm{N}$ did not significantly increase DM production of sudangrass. Each additional $\mathrm{kg}$ of $\mathrm{N}$ may increase yield linearly to about $11.4 \mathrm{~kg} \mathrm{DM} \mathrm{ha}^{-1}$ each season (Stafford et al., 2004; Jung and Reid, 1966). Environmental conditions such as low soil moisture affect the response of yield to N. Jung and Reid (1966) reported an interaction between $\mathrm{N}$ fertilization and low soil moisture. Hart and Burton (1965) reported an increase in forage yield with the application of increasing amounts of $N$ up to 454 $\mathrm{kg} \mathrm{ha}^{-1}$.

Harms and Tucker (1973) investigated the influence of $N$ fertilization on yield of seven sudangrass varieties in Oklahoma and reported that $\mathrm{N}$ application 
increased forage yield in second and third clippings and not at the first clipping. Lack of effect at the first clipping may have been due to the residual effect of $\mathrm{N}$ at seeding. Jung and Reid (1966) reported an increase in tiller numbers with an increase in $\mathrm{N}$ level applied at second clipping of sudangrass. They observed that varieties and hybrids of sudangrass responded differently to the application of 57 $\mathrm{kg} \mathrm{N} \mathrm{ha}^{-1}$, however, a large increase in yield was obtained for all varieties with $227 \mathrm{~kg} \mathrm{~N} \mathrm{ha}^{-1}$.

Stage of growth at which $\mathrm{N}$ is applied has an effect in its utilization. High fertilizer $\mathrm{N}$ use efficiency in corn, a warm-season forage, is obtained when $\mathrm{N}$ is applied at the six leaf stage (Rozas et al., 2004). At this stage gaseous $\mathrm{N}$ losses are low and $\mathrm{NO}_{3}$ leaching is reduced.

Camara et al. (2003) reported that yield of winter wheat did not increase with addition of more than $45 \mathrm{~kg} \mathrm{~N} \mathrm{ha}^{-1}$ in eastern Oregon during the period 1962-1987 which was attributed to below normal precipitation. At high $\mathrm{N}$ rates, the response per kilogram of additional fertilizer $\mathrm{N}$ declined until maximum yield was attained at which point the response to additional fertilizer was zero.

Bryan (1985) reported that $\mathrm{N}$ at $168 \mathrm{~kg} \mathrm{ha}^{-1}$ per year increased yearly herbage DM accumulation of mixed pasture from $20 \%$ to $120 \%$ compared to sod seeding with red clover and birdsfoot trefoil. Collins and Balasko (1981a) investigated the effect of harvest management and $\mathrm{N}$ fertilization rates on springsummer and autumn-winter production of tall fescue. They reported that $\mathrm{N}$ fertilization increased winter tall fescue yield but the magnitude of the response was influenced by the date of initiation of stockpiling. 
Monks et al. (1997) reported that cover crops did not respond to additional application of $\mathrm{N}$ on soils with high initial $\mathrm{N}$ fertility. They further indicated that although $\mathrm{N}$ application did not consistently overcome the disadvantages resulting from late planting of cover crops in a harsh winter environment, $\mathrm{N}$ application increased yields on some cover crops planted on soils with low initial N-levels. At even higher rates of application, there was no significant effect on yield, though the response may be negative with some decrease in yield (Whitehead 1995).

\section{Forage Establishment}

The ultimate goal of good forage establishment is to obtain a dense and vigorous stand capable of producing high yields (Miller and Stritzke, 1995). Good germination of sudangrass and pearl millet takes place at temperatures from 20 to $25^{\circ} \mathrm{C}$ and seeding depths of 1.5 to $5 \mathrm{~cm}$ (Friboug, 1995). They are normally seeded in May or June when soil temperature is ideal for germination (Sumner et al., 1965; Burger and Hittle, 1967). Germination percentage increases as soil temperature rises. Brar and Stewart (1995) reported an increase in percent germination of sorghum as temperature increased from 15.5 to $26.5{ }^{\circ} \mathrm{C}$ under a controlled environment. Good stands can be obtained if competition from existing vegetation is minimized (Groya and Sheaffer, 1981). Seedling plants do not compete well with existing vegetation (Miller and Stritzke, 1995). Good forage establishment requires minimum competition from existing vegetation which can be controlled by burning and use of herbicide. 


\section{(i) Burning}

Burning may be an option for controlling cool-season vegetation before establishing annual forages. Several studies have been carried out examining the use of fire to control vegetation (Sanderson et al. 2004; Coumo et al. 1999). Sanderson et al. (2004) investigated the best time in spring to burn pasture as a strategy to control weeds that compete with warm-season grasses. They burned switchgrass (Panicum virgatum L.) and big bluestem (Andropogon gerardii Vitman) in mid-April, early May and late May at Rock Springs, PA. They reported that, compared with fire in mid-April or early May, a late May burn of weeds reduced DM yields of swichgrass or bluestem by 40 to $48 \%$ in July, but did not affect DM yield in September. They concluded that switchgrass or bluestem can be burned through the first week of May (10-15 cm growth) with little effect on yield.

Butler et al. (2002) determined the effects of three forage removal techniques (mowing plus vegetation removal, paraquat plus burning and burning after frost) for establishing clovers (Trifolium spp.) and annual ryegrass. They reported that a combination of burning and paraquat resulted in higher DM production compared to mowing. Cuomo et al. (1999) evaluated six strategies for managing warm-season annual grass residues that interfered with establishment of annual ryegrass in fall. The strategies were different combinations of burning, mowing and use of glyphosate at 1, 7 and 30 days before planting. They reported that burning and spraying of warm-season annual residues 30 days before planting annual ryegrass improved stands and forage production. Besides controlling vegetation, burning has the advantage of killing 
disease causing organisms. Rees and Platz (1998) reported that burning and cultivation reduced severity of yellow spot of wheat, which also affects cereal rye and triticale.

\section{(ii) Herbicide}

Williams et al. (2002) stated that, in no-till cultivation, herbicides are used to suppress the sod but do not control forbs that re-emerge later and compete with new seedlings. One such herbicide is glyphosate. Glyphosate blocks the synthesis of amino acids used as the building blocks for protein synthesis. Amino acid synthesis inhibitors act on a specific enzyme to prevent production of amino acids thereby affecting plant growth and development (Weed Control Manual, 2000).

Timing of a spring herbicide application is important as it controls vegetation that may compete with seeded plants. Various studies have shown that herbicide can be used to control weeds and undesired grass species that compete with preferred species. Sanderson et al. (2004) applied glyphosate to switchgrass and big bluestem in mid-April, early May and late May. They reported that in switchgrass, glyphosate applied in late May reduced July yields by $70 \%$ and September yields by $30 \%$. In bluestem, late May application of glyphosate reduced July yields by $90 \%$. They concluded that glyphosate should be applied before mid- to late April (just before green-up) if switchgrass or big bluestem is to be harvested as hay in July and by the first week of May if the cumulative growth is to be harvested once in autumn. Robinson and Wittmus 
(1973) evaluated herbicides for use in zero and minimized tilled corn and sorghum in Nebraska. They reported that all herbicide treatments reduced weed populations and resulted in increased yields compared to the cultivated check. Hart et al. (1971) determined the effects of rates of paraquat and post-seeding management on establishment and yield of sorghum $x$ sudangrass hybrids (Sudax) seeded into tall fescue sod. They reported that Sudax seeded into sprayed sod established and produced less forage than Sudax planted in a prepared seedbed.

Laberge et al. (2005) compared establishment in perennial cool-season grass sods of sod-seeded Kura clover (Trifolium ambiguum M.B.), red clover (Trifolium pratense L.) and white clover (Trifolium repens L.) using different herbicide sod suppression intensities (paraquat at $0.9 \mathrm{~kg}$ a.i. $\mathrm{ha}^{-1}$ and glyphosate at 0.8 or 3.3 $\mathrm{kg}$ a.i. ha ${ }^{-1}$, without or with $\mathrm{N}$ fertilization at $110 \mathrm{~kg} \mathrm{~N} \mathrm{ha}^{-1}$ ). They reported that during the establishment year plant density and DM production of Kura clover (90 plants $\mathrm{m}^{-2}, 390 \mathrm{~kg} \mathrm{DM} \mathrm{ha}^{-1}$ ), was generally inferior to white clover (110 plants $\mathrm{m}^{-}$ ${ }^{2}, 740 \mathrm{~kg} \mathrm{DM} \mathrm{ha}^{-1}$ ) and red clover (170 plants $\mathrm{m}^{-2}, 1,450 \mathrm{~kg} \mathrm{DM} \mathrm{ha}^{-1}$ ). Paraquat did not suppress the sod sufficiently, resulting in lower legume populations and yields than glyphosate. Sod suppression using glyphosate, however, led to heavy seeding-year weed infestation at two of three sites in Minnesota (2,200 kg weed DM ha ${ }^{-1}$ ). Sod-seeded Kura clover successfully established with glyphosate; however, its contribution to forage production in the seeding year remained minimal ( $<0.5 \mathrm{t} \mathrm{ha}^{-1}$ at four of five sites). 


\section{Forage quality}

Forage quality is a combination of biochemical and anatomical characteristics that produce an animal response (Collins and Fritz, 2003; Pearson and Ison, 1997). This response can be the amount of meat, milk, wool or work obtained from an animal when a given forage is consumed (Barnes and Nelson, 2003). The response is due to the amount and availability of nutrients in a feed. Commonly used measures of forage quality are nonstructural carbohydrate, crude protein (CP), and neutral detergent (NDF) and acid detergent fiber (ADF) (Undersander, 2004). Crude protein is the second most limiting nutrient for the ruminant animal. It is normally $10-15 \%$ of total DM in forages (Collins and Fritz, 2003). Crude protein is defined as the amount of $\mathrm{N}$ multiplied by 6.25 . Protein is required for growth and repair of various tissues in the body of animals (Minson, 1990). The NDF fraction is mainly the structural component of forage and consists of lignin, cellulose and hemicellulose (Collins and Fritz, 2003). The NDF is an indicator of the quantity of the feed an animal can consume. The amount of NDF in forage limits intake. The ADF fraction is the residue that remains after boiling a forage sample in an acid detergent solution. This portion of the feed is mainly cellulose and lignin (Van Soest et al., 1991). The ADF indicates the digestibility of the forage, high levels limit digestibility.

Previous reports (Hall, 2004; Piaggio and Prates, 1997; Moore et al., 2004, Balasko, 1977, Lopez-Dominguez et al., 2001) have shown that forage quality is affected by plant and environmental factors including forage maturity, 
species, $\mathrm{N}$ application rate and timing, and season of the year. Quality declines and DM production increases as forages develop from vegetative to flowering stage. Jung and Reid, (1966) reported that as sudangrass increased in maturity, DM yield increased and CP concentration decreased. Similarly, Moore et al. (2004) reported that warm-season perennials lost quality more quickly than coolseason perennials as the grazing season progressed in lowa.

Differences in CP concentration among species have been reported. Clark et al. (1965) reported that in July, CP concentration of pearl millet ranged from 21 to $27 \%$, while that of sudangrass and a sorghum-sudangrass hybrid varied from 18 to $22 \%$. Heringer and Moojen (2002) concluded that higher rates of $\mathrm{N}$ increased CP concentration of pearl millet stems. Hart and Burton (1965) reported that application of up to $454 \mathrm{~kg} \mathrm{~N} \mathrm{ha}^{-1}$ increased CP and slightly decreased crude fiber concentration of pearl millet in one of the three years studied.

Studies by Balasko (1977) to determine the effects of N, P, and K fertilization on yield and quality of tall fescue regrowth in late fall and winter indicated that $\mathrm{N}$ fertilized forage was better in quality than both unfertilized, and $\mathrm{P}$ and $\mathrm{K}$ fertilized forage as harvest was delayed from December to January. Collins and Balasko (1981b) examined the effects of $\mathrm{N}$ fertilization and cutting schedule on quality of stockpiled tall fescue, and found that $\mathrm{N}$ fertilization increased concentrations of $\mathrm{CP}$, total non-structural carbohydrates (TNC) and in vitro dry matter disappearance (IVDMD). They further reported that delay of last 
summer harvest also improved forage quality. Rayburn (1977) reported that quality of tall fescue increased with later dates of stockpiling and fertilization. Redfearn et al. (2002) evaluated nutritive value of annual ryegrass cultivars. They reported that protein concentration differed significantly among harvests with a general decrease from 260 to $120 \mathrm{~g} \mathrm{CP} \mathrm{kg}^{-1}$ as the growing season progressed. Wiedenhoeft and Barton (1994) determined that nutritive quality of initial and regrowth of three brassica species, rape, turnip, and a turnip hybrid was influenced by planting and harvest date. They were planted in late May to early June, late June to early July, and late July to early August and were harvested each year at 64,76 , or 85 DAP (days after planting). Plants regrew 60,70 , or $80 \mathrm{~d}$ and were harvested. They reported that nutritive levels declined with warmer temperatures and low moisture levels particularly during July and August. They concluded that brassica herbage was more comparable to a concentrate than traditional forage because of relatively low fiber and higher protein content. Jung and Shaffer (1993) investigated the effect of planting date on the CP concentration of turnip. They reported that turnip from an August planting had a mean CP concentration of $21 \mathrm{~g} \mathrm{~kg}^{-1}$ higher than turnip from June planting. They further reported that mean protein concentration was lowest (242 $\left.\mathrm{g} \mathrm{kg}^{-1}\right)$ in 1986, when yields were high, and was highest $\left(281 \mathrm{~g} \mathrm{~kg}^{-1}\right)$ in 1987 , when yields were low. Wiatrak et al. (2004) reported that increasing $N$ application rates from 0 to $200 \mathrm{~kg} \mathrm{ha}^{-1}$ to the previous crop decreased NDF in notill wheat and increased DM production. 


\section{Anti quality factors}

Some forage species, including tall fescue, sudangrass, and annual ryegrass produce substances that affect intake. An endophyte is associated with tall fescue, grass tetany with ryegrass and prussic acid with sudangrass (Ball et al., 1996). Endophyte infected tall fescue produces ergopeptine alkaloids that may be associated with fescue toxicity in cattle. The endophyte is a fungus that lives in a symbiotic relationship inside the grass plant. Although the endophyte does not harm the grass it produces toxins that are harmful to livestock. Growth of infected plants is enhanced, they are more drought tolerant and resistant to certain insects.

Prussic acid poisoning occurs as a result of an animal consuming plant materials that are high in cynogenic glycosides. These cynogenic glycosides, once in the stomach, are broken down to glucose and a non-carbohydrate residue by enzymatic hydrolysis. The non-carbohydrate residue $(\mathrm{HCN})$ when absorbed by the animal body is toxic in the blood as it combines with hemoglobin and affects oxygen transport. Cynogenic glycosides are produced by plants such as sudangrass, sorghum, johnsongrass, chokecherry, and black cherry (Ball et al., 1996). Sudangrass is also associated with nitrate poisoning. Nitrate poisoning results from heavy $\mathrm{N}$ fertilization followed by severe drought. One or split applications of $\mathrm{N}$ did not affect nitrate concentration in the leaves of sudangrass in Oklahoma (Selk et al., 1993). 
Annual ryegrass has a grass tetany potential (Haby and Robinson, 1997). Grass tetany is a condition associated with low levels of $\mathrm{Mg}$ in the grass. Incidence of grass tetany in animals grazing annual ryegrass is frequently increased by $\mathrm{N}$ fertilization, largely due to changes that lower forage $\mathrm{Mg}$ availability to ruminant animals. Other factors responsible include increased concentrations of $\mathrm{CP}$, higher fatty acids concentration, and organic acids and lower concentrations of water-soluble carbohydrate and Mg (Haby and Robinson, 1997).

\section{Physiological maturity of warm-season annuals}

Stage of maturity is critical to forage management decisions. Knowing when to graze or cut annual forages is an important aspect of forage management especially when the aim is to maximize production and maintain a good stand of grass (Frank, 1996). Frank stated that plant development and growth are processes that contribute to forage grazing readiness.

Moore et al. (1991) described and quantified growth and development stages of forage grasses based on a universal set of morphological descriptors for forages and a continuous numerical index. They divided the life cycle of individual grass tillers into five primary growth stages, namely; germination, vegetative, elongation, reproductive, and seed ripening. Germination encompasses the events occurring when the seed is placed in the soil; the vegetative stage refers to the developmental period comprising leaf growth and development; elongation is the stage during which culm elongation occurs and is 
often called jointing; and the reproductive stage begins with emergence of the inflorescence and continues through anthesis and fertilization. Each growth stage was assigned a mnemonic code and a numerical index. The indices were; germination, 0-0.9, vegetative, 1.0-1.9, elongation, 2.0-2.9, reproductive, 3.0-3.9 and seed development, 4.0-4.9. The numerical index was used to describe the stage quantitatively.

Other methods of determining physiological maturity have been developed. Kalu and Fick (1981) developed a method of quantifying morphological development of alfalfa. They defined a 10-stage numerical system for individual stems. They used two procedures for calculating the mean developmental stage of herbage samples, mean stage by count (MSC) and mean stage by weight (MSW). The MSC was the average of the individual stages present in the herbage sample while the MSW was the average of individual stages present, weighted for dry weight of herbage in each stage. They reported that the relationship between CP and morphological stages was consistent across season. Haun (1973) developed a numerical expression of morphological development based on the number of leaves produced on the main stem of wheat. Zadoks et al. (1974) developed a decimal code to describe growth stages of cereals.

\section{Grassland production systems}

A system as defined by Allen and Collins (2003) is an integration of components with the intention of accomplishing specific goals or outcomes. Beef production systems in Appalachia are classified as cow calf, backgrounding, and 
finishing. This classification is based on the growth phases of the beef animal before it is finally slaughtered and consumed. A forage production system involves all components that go towards producing forage. The forage is in turn converted to beef. The parts of a forage production system are; forage species, the soil, environment, and management.

A survey conducted in WV by Lozier et al., (2004) indicated that about $74 \%$ of calf producers practice spring calving, $10 \%$ practice fall calving and $16 \%$ produce calves all year round. Forage is the main feed for beef cattle. The most common forages in this region include orchardgrass, tall fescue, Kentucky bluegrass, timothy, white clover, and red clover. Annual forages found in most grassland systems include ryegrass, forbs, crabgrass, brassicas, oats, wheat, triticale, sudangrass, and pearl millet. Legumes are important in both pastures and hayfields but more so in pastures. Cool-season grass-clover mixtures are the most important forage combinations.

Different strategies have been evaluated to manage seasonal distribution of forages. These have included grazing hayfields during those periods of the year when hay is traditionally fed (Baker et al. 1988, Prigge et al., 1999). Baker et al. (1988) compared four grassland management systems applied to tall fescue and orchardgrass meadows. The systems were: early spring grazing, one hay cutting, and late fall grazing; two cuttings of hay; early spring grazing and two cuttings of hay; and one hay cutting and late fall grazing. The study concluded that systems involving early spring grazing provided higher quality herbage compared to the other two systems in which meadows were ungrazed in 
spring, however, there was a reduction in annual DM production. Prigge et al. (1999) evaluated four grassland management systems imposed on orchardgrass and fescue fields overseeded with red clover. This study concluded that fall grazing after a single hay cut produced more annual DM than either two hay cuttings or other combinations of grazing or cutting regimes. Moore et al. (2004) evaluated the impact of legumes on productivity and nutritive value of coolseason pasture grazed in spring and fall, and warm-season forage grazed in summer. They reported that a grass-legume mixture resulted in a higher total liveweight gain. They also added that warm-season forages declined in quality more rapidly than cool-season pasture during the summer grazing period. Flaherty (1992) compared two 12-month cow calf production systems; conventional and flexible. The conventional system resembled a typical West Virginia beef cow-calf operation, while the flexible system involved a continuously stocked area that was varied in size by moving an electric fence according to herbage mass and timing of hay harvest. He reported that the flexible system had a higher average net return than the conventional one. Bryan et al. (1986) compared conventional and innovative systems for cow-calf production and reported that net present value for the innovative system was significantly greater than the conventional. Choat et al. (2003) investigated the effects of grazing dormant native range or winter wheat pasture on subsequent finishing cattle performance, carcass characteristics, and ruminal metabolism in Oklahoma and reported that grazing winter wheat before finishing resulted in fewer days on feed, increased hot carcass weight and improved carcass quality. The use of 
brassicas as a forage in the late fall and early winter provided high yields of DM with high carrying capacity of sheep (Reid et al. 1994). In another study done in Rock Springs, PA, Jung and Shaffer (1995) reported that sheep fed on brassica gained weight while those on grass legume herbage lost weight. They concluded that incorporating brassica cultivars into grazing systems could reduce animal production costs by providing high quality forage for late fall grazing. Schwarte et al. (2005) conducted research in lowa during the period $2002-2004$ to identify the best date of planting triticale that allowed maximum DM production. They concluded that triticale should be planted in September to maximize spring forage yield.

Year-round grazing systems have been reported to be successful (Janovick et al., 2004, Allen et al., 1992). Janovick et al. (2004) concluded that a year-round grazing system using grass-legume pastures and corn residues reduced the amount of hay needed to feed cows and calves over winter compared to feeding hay in drylot and provided a better way of managing risk for summer grazing in drought years. Allen et al. (1992) developed year round grazing systems for spring-calving beef cows where a mixture of fescue-red clover and fescue-ladino clover produced a high calf weaning weight. Forwood et al. (1988) compared season long grazing behavior of steers grazing tall fescue + clover with a complementary grazing system involving tall fescue + clover utilized during spring and fall and big bluestem, a warm season grass, during mid summer. They reported a low grazing time, increased daily gain and high 
herbage intake on the complementary grazing system during mid summer 1987 , illustrating the advantage of using warm-season grass at that time.

\section{Management strategies}

Pasture availability during the year is variable while animal requirements are usually constant. Therefore, a good management strategy is to have yearround growth of forages with minimal fluctuation (Humpreys, 1978). This does not occur in most practical situations, therefore, the following strategies can be used; supplementation, reduction of stocking rate, forage stockpiling, and preservation. Supplementary feeding is the identification and provision of limiting nutrients, especially minerals (Purser, 1981). Pastures themselves may be seen as supplements if they provide a source of a specific nutrient such as protein in a grazing system based on poor quality native pasture (Pearson and Ison, 1997).

Gunter et al. (2002) investigated the pasturing of winter annual forage as a supplement feed for beef cows. They sorted 120 pregnant beef cows into six groups stratified by body condition score, BW, breed, and age, and randomly assigned each group to one of six 5.1-ha dormant bermudagrass pastures. All cows had ad libitum access to bermudagrass/dallisgrass hay. They compared three treatments; a concentrate based supplement fed $3{\mathrm{~d} w k^{-1}}^{-1}$ limited grazing

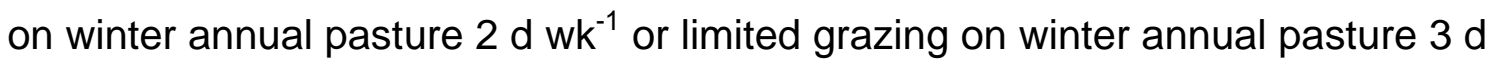
$\mathrm{wk}^{-1}$. Winter annual pasture consisted of a mixture of wheat and rye in experiment one and a mixture of wheat, rye, and annual ryegrass in experiment two, sod-seeded into a portion of the pasture. They reported that limited grazing 
of a mixture of wheat and ryegrass pasture was comparable to the concentrate based supplement. Limited grazing for 2 compared to $3 \mathrm{~d} \mathrm{wk}^{-1}$ did not affect $(\mathrm{P}>$ $0.15)$ cow BW.

Stockpiling involves carrying over pasture that is not utilized in the season in which it was grown but is left standing to be grazed in a subsequent season (Pearson and Ison, 1997). Allen et al. (1992) reported that stockpiled tall fescue minimized the need for stored forage from November to April in Virginia. Forage, in excess, can be preserved and fed to animals during the time of deficit. Two forms of preservation are hay and silage (Pitts, 1990). Hay is usually below $20 \%$ moisture and silage preserved by anaerobic fermentation (Collins and Owens, 2003). Forage preservation is aimed at minimizing losses and maintaining quality (Pitts, 1990). However, biological processes that take place during preservation are detrimental to the quality of forage. Effluent resulting from the process of making and storing silage can result in environmental pollution (Graves and Vanderstappen, 1993).

\section{Economic analysis of grassland systems}

Economic analysis of any grassland system can be conducted using an enterprise budget. An enterprise budget represents costs and returns of a given crop or livestock production activity (Moore and Nelson, 1995). Factors of production (land, labor, capital, and management) are used to calculate the cost of production. Each factor is allocated a return even if a cash cost is not involved. An enterprise budget guides farmers in decision making. 
Economic analyses for grassland production systems have been reported. D'Souza et al. (1988) evaluated the investment potential of using warm-season grasses for beef cattle feeding on hill-land areas such as those in West Virginia. They compared costs and returns of warm-season grasses with those of coolseason grasses. In their comparison they used four grazing systems and various species of cool-season and warm-season forages. They reported that pasture systems incorporating warm-season species yielded higher annual returns than those using conventional, cool-season grasses. In another study, D'Souza et al. (1990) quantified the economic impact of substituting pasture for harvested forage for beef cow/calf production and concluded that extended grazing can be a more profitable option than feeding hay for cow/calf production because of a reduction in production costs. Evans (2003) used stochastic budgeting to compare profit and risk levels experienced by grass-finishing and traditional beef producers. His results showed that producers raising beef on pasture face greater costs than those practicing traditional methods because of longer animal retention, more intensive pasture management, processing expenditure, and seeding and fencing start-up costs. 


\section{CHAPTER THREE: MATERIALS AND METHODS}

The research was conducted in 2004 and 2005 on two adjacent sites in a naturalized grassland at the Reedsville Experimental Farm $\left(39^{\circ} 50^{\prime} \mathrm{N}\right.$ lat: $79^{\circ} 83^{\prime}$ W longitude and altitude of 537 meters above sea level), West Virginia. The soils were in the Wharton series (clayey, mixed, mesic Aquic Hapludults). Both sites had 3-10\% slope, the 2004 site facing west and the 2005 site facing north. Four weeks before planting soil was sampled along the diagonal by taking cores to a depth of $5 \mathrm{~cm}$. Fifteen cores were taken from each block, and they formed one sample. Samples were air dried and analyzed for P and K (Mehlich, 1953) and pH (Shoemaker et al., 1961). Soil test results are presented in Table 1 of the appendix. The predominant species were Kentucky bluegrass, orchardgrass, tall fescue, and white clover.

The experimental treatments consisted of two warm-season annual forages, sudangrass and pearl millet, grown in summer followed by cool-season annual forages, triticale and a mixture of annual ryegrass, and turnip grown in fall on the same land, and also a control. The control consisted of the existing natural grass/legume mixture. Two methods of vegetation control prior to seeding, burning and glyphosate application, were compared. Three levels of $\mathrm{N}$ $\left(0,100\right.$, and $\left.200 \mathrm{~kg} \mathrm{~N} \mathrm{ha}^{-1}\right)$ were applied to the annual forages and the control.

The experiment was in a randomized complete block design with multiple split plots. The two warm-season annuals, sudangrass and pearl millet, were main plots, and the two methods of vegetation control formed the first split. The plots assigned to each method of vegetation control were subdivided into three 
and the three levels of $\mathrm{N}$ treatments were assigned at random. The $\mathrm{N}$ treatments received 0,100 and $200 \mathrm{~kg} \mathrm{ha}^{-1} \mathrm{y}^{-1}$ split into two equal parts and applied by hand in summer and in fall. In August, after harvesting the warm-season annuals the main plots were split and seeded to triticale or the mixture of annual ryegrass and turnip. The treatments were replicated four times. The main plots (summer annuals) measured $15 \mathrm{~m} \times 12 \mathrm{~m}$, first subplots (vegetation control) were $15 \mathrm{~m} \times$ $6 \mathrm{~m}$, and second subplots $(\mathrm{N})$ measured $5 \mathrm{~m} \times 3 \mathrm{~m}$ in size. The procedure for each of the seasons is described below.

\section{Summer annuals}

Starting in late April, soil temperature was monitored. When the soil temperature reached $12^{\circ} \mathrm{C}$ plots were planted with a Tye no-till seeder. Naturalized grassland was burnt and sprayed on May 10, 2004, and May 16, 2005. Prior to burning, naturalized grassland was harvested and biomass determined. The naturalized grassland was sprayed with glyphosate (480 grams active ingredient per liter in the form of isopropylamine) at a rate of 2.4 liter ha ${ }^{-1}$ using a boom sprayer. Burning was done with a flame cultivator (width of $1.27 \mathrm{~m}$ ) that used propane gas. Propane was used at a rate of 56.8 liters ha ${ }^{-1}$. Burning was repeated on May 24, 2004 and May 31, 2005 immediately before planting. Sudangrass hybrid SS 120 and pearl millet hybrid SS 635 were seeded at the rate of 78 and $45 \mathrm{~kg} \mathrm{ha}^{-1}$, respectively. Seeding depth was $2.5 \mathrm{~cm}$ and row width was $20 \mathrm{~cm}$. Control plots were harvested at the time of seeding. Urea was applied on May $25^{\text {th }}, 2004$ and June $2^{\text {nd }}, 2005$, at the rate of $50 \mathrm{~kg} \mathrm{~N} \mathrm{ha}^{-1}$ to both 50 and $100 \mathrm{~kg} \mathrm{~N} \mathrm{ha}^{-1}$ treatments and a second application at the same rate made 
on June $21^{\text {st }}, 2004$ and June $30^{\text {th }}, 2005$ to plots designated to receive $100 \mathrm{~kg} \mathrm{~N}$ ha $^{-1}$. Starting on June $24^{\text {th }}$, height of both sudangrass and pearl millet was measured weekly at specific spots in blocks 1 and 4 . A second harvest of the control plots was made on June $29^{\text {th }}, 2004$ and July $25^{\text {th }}, 2005$. On July $19^{\text {th }}$, 2004, pearl millet plots that established following burning were harvested. Pearl millet failed to germinate on this treatment. Sudangrass and pearl millet were harvested on August 6, 2004 and August 4, 2005. In summer, all forages were harvested at $5 \mathrm{~cm}$ using a sickle bar mower. A border area of $0.53 \mathrm{~m}$ was cut from each end of the plot, and the cut material was discarded. A center strip was then clipped, weighed, sampled (approximately $500 \mathrm{~g}$ ), and stored in a deep freezer. Samples were hand separated to determine botanical composition. These samples were then dried at $70^{\circ} \mathrm{C}$ for 48 hours, weighed, and ground in a Wiley mill to pass a $1 \mathrm{~mm}$ screen.

\section{Method of determining morphological stages of sudangrass and pearl millet}

Prior to harvesting sudangrass and pearl millet, a random quadrant (area of $0.60 \mathrm{~m}$ by $0.60 \mathrm{~m}$ ) was selected and clipped using a hand clipper within the strip where the forage was to be harvested. Fresh weight of the clipped material was taken and added to the weight of material from the harvested strip for the calculation of the total DM yield of the plot. The clipped material was separated into growth stages, namely; vegetative $(V)$, elongation $(E)$ and reproductive $(R)$ as described by Moore et al. (1991). All tillers from each stage were dried and 
weighed. Mean stage by weight (MSW) was determined using the procedure of Moore et al. (1991).

\section{Fall annuals}

Plots assigned to each of the $\mathrm{N}$ and vegetation control treatments remained the same as in summer. Each main plot (sudangrass and pearl millet in summer) was split and randomly assigned to either triticale or a mixture of annual ryegrass and turnip. However, the control plots remained the same as in summer. Vegetation was burnt and glyphosate applied on August $10^{\text {th }}, 2004$, four days after harvest of summer annuals. In 2005, 12 days were allowed between the harvest of summer annuals and application of vegetation control methods to allow vegetation to grow and for herbicide action to be effective. Plots were seeded on August $24^{\text {th }}$ in both 2004 and 2005 using a Tye no-till seeder at seed rates of $70 \mathrm{~kg} \mathrm{ha}^{-1}$ for triticale, $50 \mathrm{~kg} \mathrm{ha}^{-1}$ of annual ryegrass and $3.4 \mathrm{~kg} \mathrm{ha}^{-1}$ for turnips. Nitrogen was applied immediately after seedling emergence at 50 and $100 \mathrm{~kg} \mathrm{ha}^{-1}$ to those plots assigned those treatments in summer.

Harvesting commenced on November $16^{\text {th }}$ and $15^{\text {th }}$ in 2004 and 2005, respectively. Prior to harvesting, forage height was measured using a plate meter as described by Rayburn and Rayburn, 1998. Forage was cut inside a quadrat of $0.20 \mathrm{~m}$ by $0.40 \mathrm{~m}$ at soil level, using a hand clipper. Four samples were taken per plot. 


\section{Chemical analysis}

Crude protein (CP), total digestible nutrients (TDN), non structural carbohydrate (NSC), acid detergent fiber (ADF) and neutral detergent fiber (NDF) were determined by near infrared reflectance spectroscopy (NIRS). The determinations were made by Dairy One* using methods described by Windham et al. (1989).

\section{Cost and benefits analysis}

Enterprise budgets were developed to compare the costs (establishment, fertilizer and harvest) and returns from annual forages compared to naturaliized grassland. Total cost of production was estimated using standard budgets that identify variable costs. Variable costs included costs that vary proportionally with the area planted, fuel, labor/machinery, seeds, fertilizer, and herbicide.

Seeds were purchased locally and their costs are given in Table 1. Cost of spraying and burning are based on commercial rates. For a typical commercial boom sprayer, which is $9.144 \mathrm{~m}$ (30 feet ) wide with a speed of $6.4 \mathrm{~km} \mathrm{hr}^{-1}$, the cost of spraying was $\$ 12.50 \mathrm{ha}^{-1}$ (Source: Rayburn, personal comm.). The cost of glyphosate was $\$ 17.75$ liter $^{-1}$. The cost of burning, based on the recommended rate for Vineyard and Orchard Flamers (Red Dragon GP-1000) that uses 46.8 liters ha ${ }^{-1}$ at speed of $8 \mathrm{~km} \mathrm{~h}^{-1}$, with width of $1.75 \mathrm{~m}$ (70") was \$ $21.43 \mathrm{ha}^{-1}$. The cost of propane gas was $\$ 0.50$ liter $^{-1}$. The cost of $N$ fertilizer was $\$ 0.81 \mathrm{~kg}^{-1}$.

\footnotetext{
* Dairy One, Forage Lab, 730 Warren Road, Ithaca, NY, 14850.

${ }^{* *}$ Flame Engineering manual
} 
Table 1. Costs of variable inputs.

\begin{tabular}{lccc}
\hline Seeds & unit cost $\left(\$ \mathrm{~kg}^{-1}\right)$ & seed rate $\left(\mathrm{kg} \mathrm{ha}^{-1}\right)$ & Total cost $\left(\$ \mathrm{ha}^{-1}\right)$ \\
\hline Pearl millet & 1.57 & 45 & 70.65 \\
Sudangrass & 2.11 & 78 & 164.58 \\
Turnip & 17.49 & 3.4 & 59.47 \\
Annual ryegrass & 1.76 & 50 & 88.00 \\
Triticale & 0.55 & 70 & 38.50 \\
\hline
\end{tabular}

\section{Statistics analysis}

Dry matter accumulation by season and summed over seasons, CP, TDN, ADF, and NDF concentrations were analyzed by analysis of variance (ANOVA) using the GLM procedure of SAS (SAS,2000). The effect of summer crops, nitrogen and vegetation control and their interactions was tested using block $\mathrm{x}$ summer crop $\mathrm{x}$ nitrogen $\mathrm{x}$ vegetation control as the error term. The effect of fall crops and interactions with the factors above were tested using the block $\mathrm{x}$ fall crop $\mathrm{x}$ summer crop $\mathrm{x}$ nitrogen $\mathrm{x}$ vegetation control as the error term. Year effects and all interactions with year were tested with the residual error term. Contrasts were used to compare warm-season annuals and cool-season annuals with cool-season perennial forage (control). Contrasts were used to compare different sequences of warm- and cool-season crops. Tests of significance were made at the 0.05 probability level unless otherwise noted. 


\section{CHAPTER FOUR: RESULTS AND DISCUSSION}

\section{Soil analysis}

The soil used for the 2004 site had an average $\mathrm{pH}$ of 6.6 while the 2005 site had a pH of 6.1. The low pH of the 2005 site made it necessary to apply lime at a rate of $900 \mathrm{~kg} \mathrm{ha}^{-1}$. The lime was applied before planting using a fertilizer spreader. The 2004 site had $18.8 \mathrm{~kg} \mathrm{ha}^{-1}$ more available phosphorus than the 2005 site, but the 2005 site had $43 \mathrm{~kg} \mathrm{ha}^{-1}$ more available $\mathrm{K}$ than the 2004 site (Appendix $1 \mathrm{~A}$ ). The amounts of $\mathrm{P}$ and $\mathrm{K}$ in the soils of both areas were adequate for pasture production. The available Mg for the two sites was above the West Virginia University recommendation for pasture.

\section{Weather conditions}

Weather data for 2004 and 2005, as recorded at the Reedsville Experiment Farm, are summarized in Figures 1 and 2. Weather in 2004 was wet and cool, whereas 2005 was warmer and drier. During 2004, temperatures were below normal from January to August with the exception of March and May, May had a mean temperature $3.0{ }^{\circ} \mathrm{C}$ above normal. Mean temperatures during June, July, and August, when warm-season forages grow best, were below normal. The cooler temperatures may account for the lower forage accumulation recorded in summer of 2004 compared to 2005. During 2005, temperatures for the months of January to August were above normal with the exception of the months of March and May that were 3.4 and $2.5^{\circ} \mathrm{C}$ below normal, respectively. This caused a one-week delay in planting of warm-season annuals in 2005. Temperatures for September and October were similar for both years. 

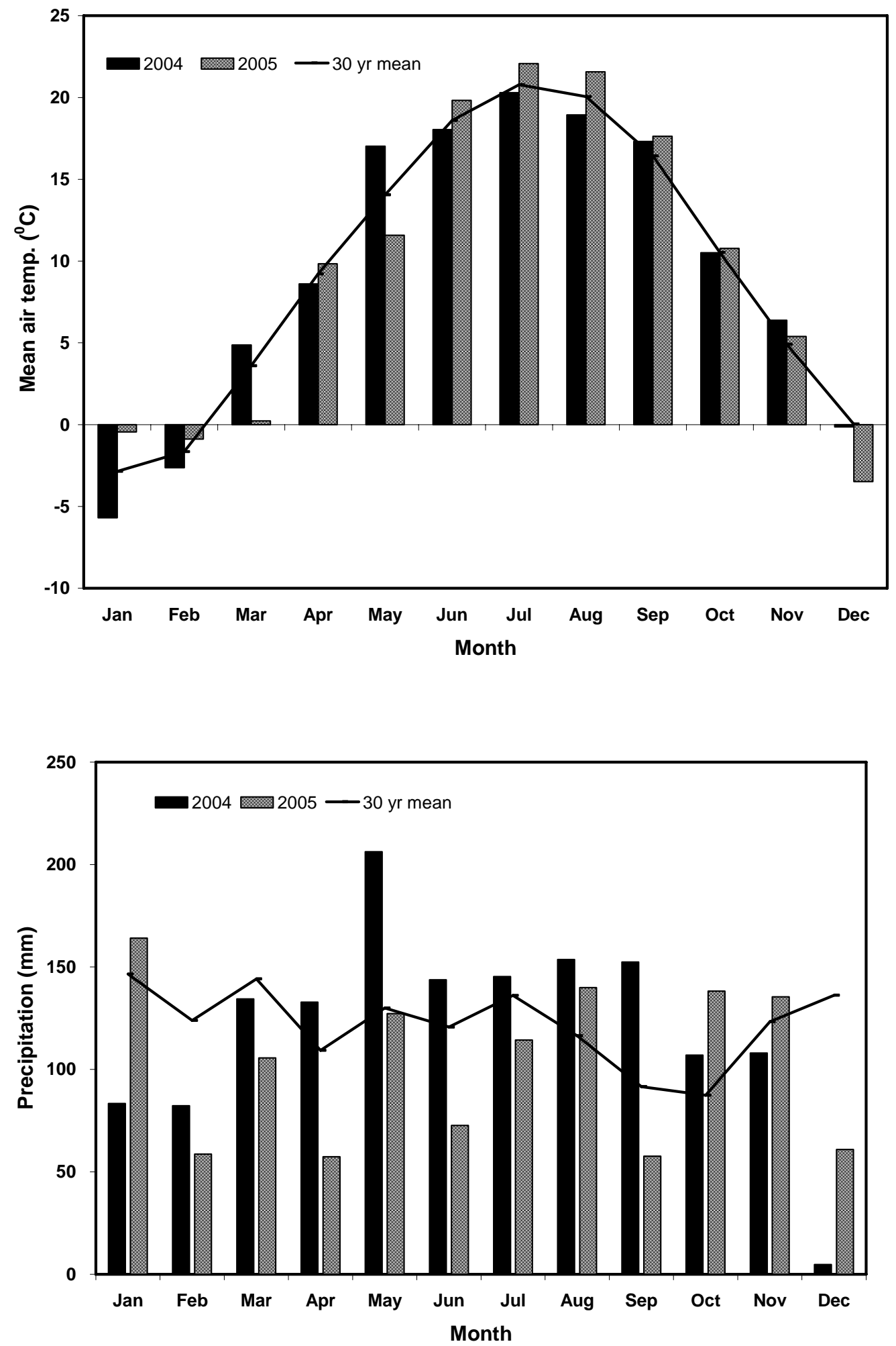

Figure 1. Monthly mean air temperature and precipitation, and 30-year mean values for each parameter at Reedsville, WV 

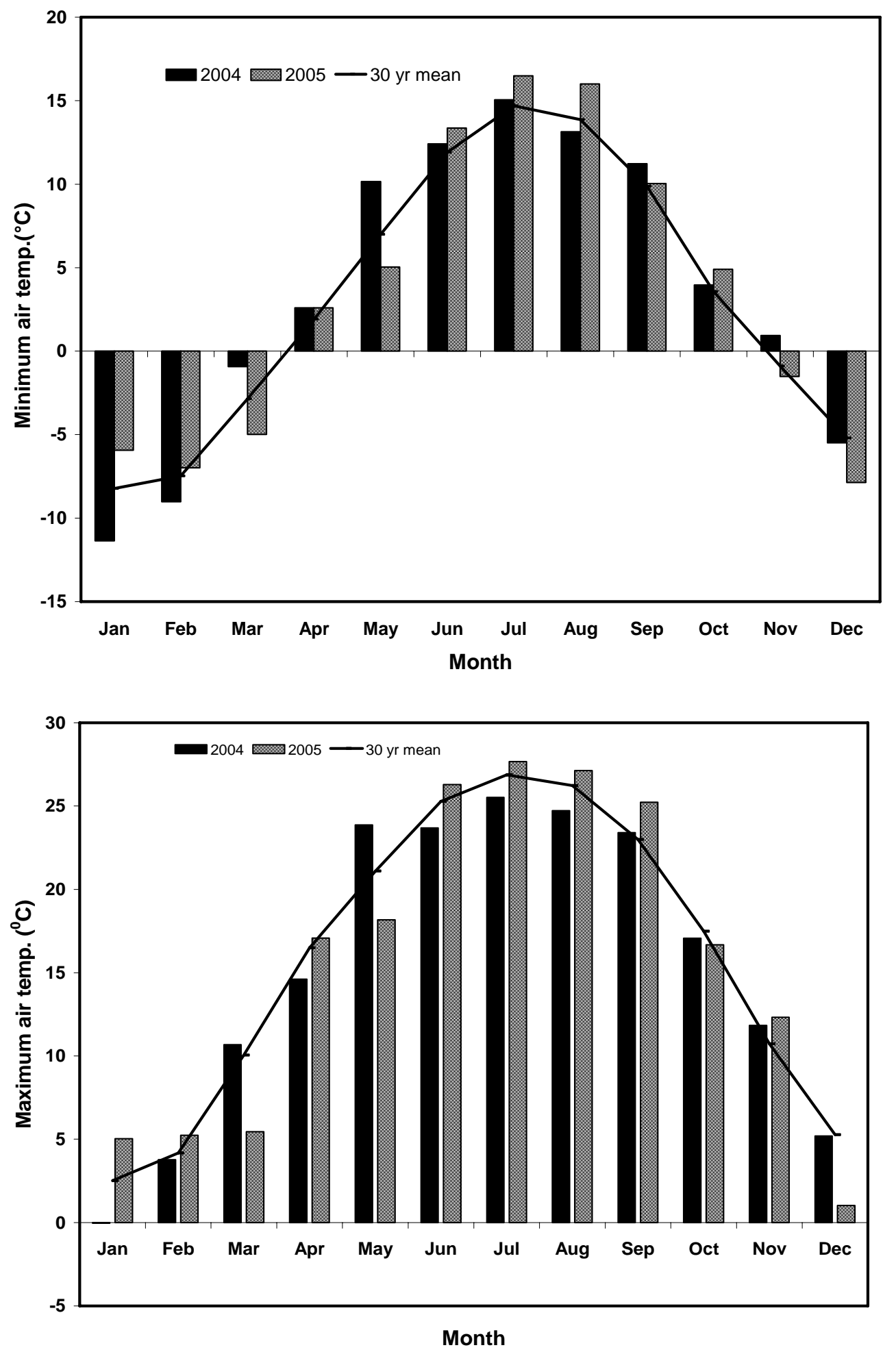

Figure 2. Monthly mean maximum and minimum air temperature and 30-year mean values for each parameter at Reedsville, WV 
Total precipitation from April to July in 2004 was $762 \mathrm{~mm}$ compared to 477 $\mathrm{mm}$ for the same period of time in 2005. Precipitation for the months of January to March 2004 was below normal, while from April to September was above normal. Monthly precipitation was more evenly distributed in 2004 than in 2005. Precipitation in 2005 was below normal for most months except January, August, October, and November. The months affected by below normal precipitation were April, June, and September.

\section{Forage accumulation}

\section{Summer period}

\section{Species}

The mean forage DM production for pearl millet, sudangrass, and naturalized pasture from late May to the end of July is shown in Figure 3, averaged across years. Sudangrass produced $1629 \mathrm{~kg} \mathrm{ha}^{-1}$ more forage than pearl millet, and $2716 \mathrm{~kg} \mathrm{ha}^{-1}$ more than naturalized pasture. Pearl millet produced $1087 \mathrm{~kg} \mathrm{ha}^{-1}$ more forage than naturalized pasture. There was no significant interaction between species and year. However, DM production was $1667 \mathrm{~kg} \mathrm{ha}^{-1}$ higher in 2005 than 2004, because of more favorable temperatures during the months of June and July (Figure 1). Although, precipitation in 2005 was below normal, it was enough for the growth of both cool- and warm-season grasses. 


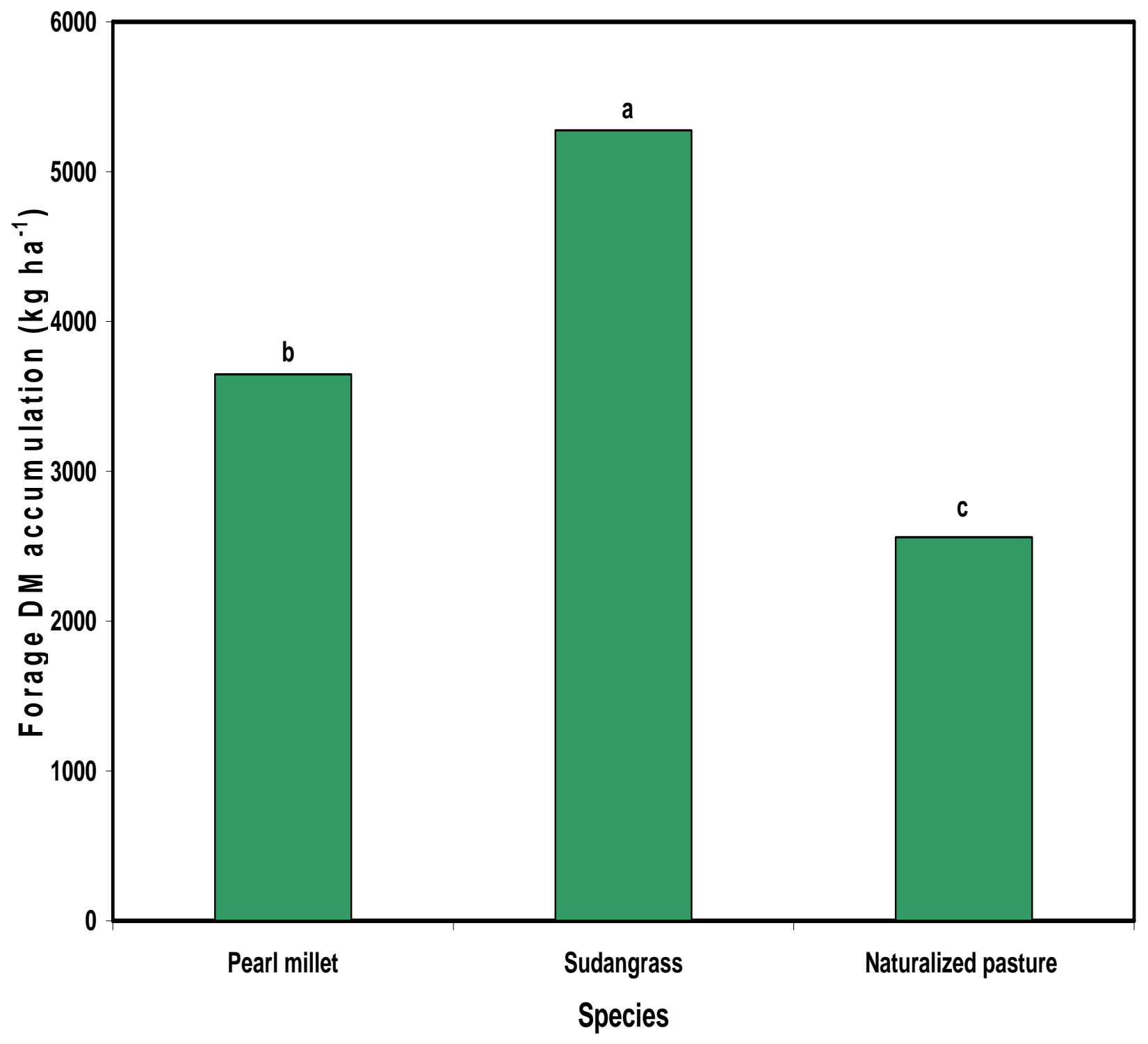

Figure 3. Effect of species on summer forage DM production. The DM production is across all vegetation control and $\mathrm{N}$ levels for sudangrass and pearl millet, and $\mathrm{N}$ levels for naturalized pasture. Bars with different letters are different at $P<0.05$. Species by year interaction not significant $(P<0.05)$. 
The finding that forage mass was highest for sudangrass followed by pearl millet is in agreement with PennState Agronomy Guide 2005-2006 which states that sudangrass is superior to pearl millet in northern Pennsylvania. Fontaneli et al. (2001) reported a higher total DM yield of sorghum-sudangrass (SX 15) compared to pearl millet cultivars. This result contrasts with the findings of Broyles and Fribourg (1959) who reported that Gahi-1 pearl millet produced more forage than sudangrass across different cutting regimes and nitrogen levels in Tennessee. However, the difference between their study and this study is that they had different varieties of sudangrass and pearl millet, and used plant height as the criteria for harvest timing. Also, this study was carried out at a higher elevation than Tennessee. In this study, one summer harvest was made based on the need to seed cool-season forages in August. Pearl millet was slow to germinate and grow compared to sudangrass. Pearl millet appeared to be more susceptible to competition than sudangrass.

Production of naturalized pasture would be expected to be low in the summer period because of high temperatures which suppress growth of coolseason forages as opposed to warm-season annuals. Naturalized pasture grows well at temperatures ranging from $5{ }^{\circ} \mathrm{C}$ and $23{ }^{\circ} \mathrm{C}$. Although in 2005 , June and July were drier than normal (Figure 1), forage accumulation for naturalized pasture may not have been affected as the temperatures were within the normal range for its growth. 


\section{Growth rate}

Growth rate was relatively low for both sudangrass and pearl millet (Figure 4) up to 30 days after seeding (DAS), thereafter rapid growth rate occurred up to 56 DAS coinciding with higher temperatures and increasing leaf area. The increase in growth rate of sudangrass and pearl millet at higher temperatures is consistent with the work of Rhykerd et al. (1960) who reported that sorghum grows best at temperatures ranging from $16{ }^{\circ} \mathrm{C}$ to $27{ }^{\circ} \mathrm{C}$. Worker, and Marble (1968) found that the highest growth rate occurred between the vegetative and boot stage for sorghum.

\section{Nitrogen fertilization}

Data for both years were combined because there were no interactions between $\mathrm{N}$ and year, and between $\mathrm{N}$ and species. Forage accumulation of all species increased as the level of $\mathrm{N}$ increased. The levels of $\mathrm{N}$ were 0,50 , and100 $\mathrm{kg} \mathrm{ha}^{-1}$ herein described as unfertilized, low, and high $\mathrm{N}$ levels, respectively. Plots that received high $\mathrm{N}$ yielded $1086 \mathrm{~kg} \mathrm{ha}^{-1} \mathrm{DM}$ more forage than the plots receiving low $\mathrm{N}$ and $1583 \mathrm{~kg} \mathrm{ha}^{-1} \mathrm{DM}$ more than unfertilized plots (Figure 5). The low $\mathrm{N}$ plots yielded $498 \mathrm{~kg} \mathrm{ha}^{-1}$ more forage mass than the unfertilized plots. The higher DM production from forage receiving $\mathrm{N}$ is in agreement with the work of Jung and Reid (1966). Hart and Burton (1965) also reported an increase in forage yield of sudangrass with increasing amounts of $\mathrm{N}$ up to $454 \mathrm{~kg} \mathrm{ha}^{-1}$. 


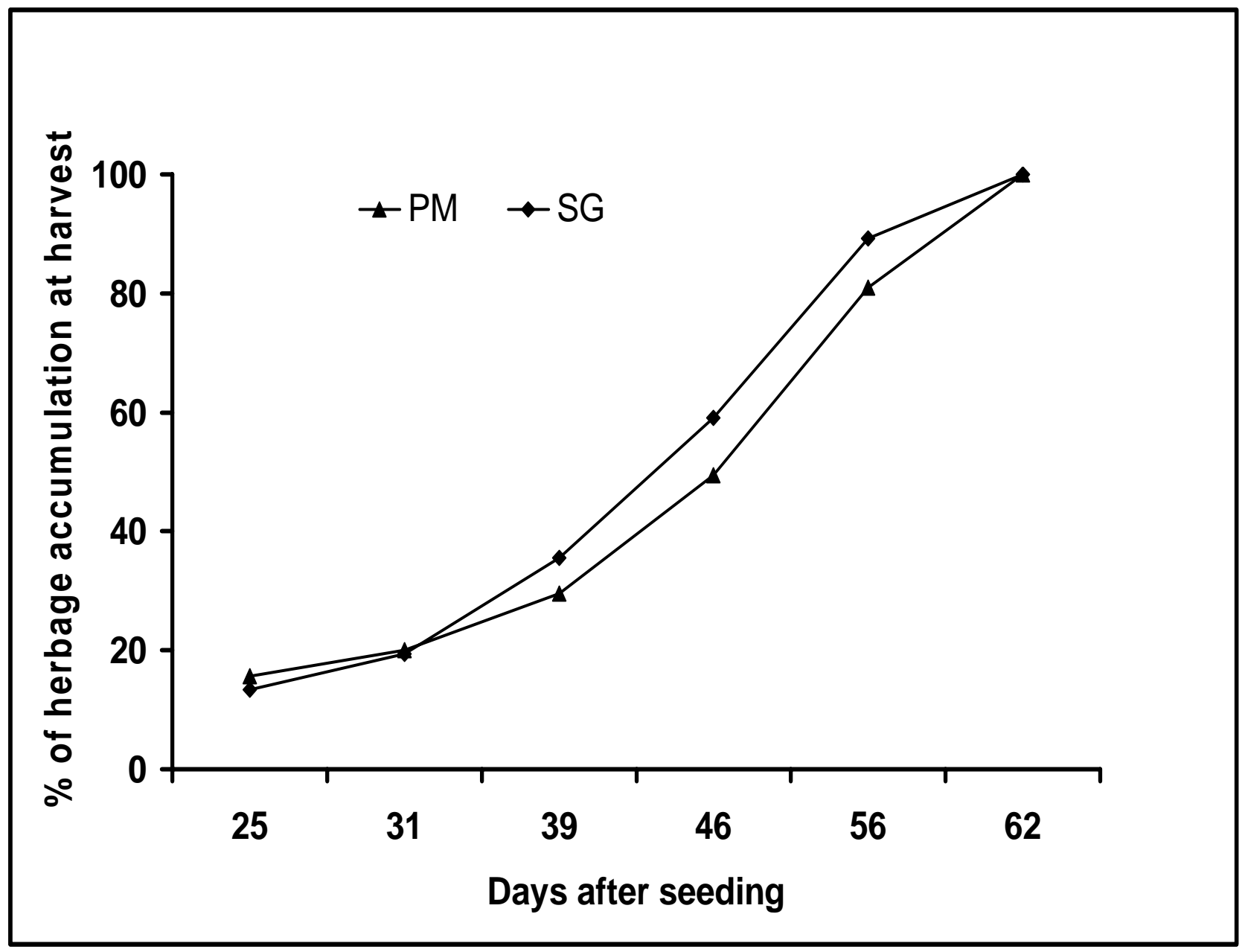

Figure 4. Growth rate of pearl millet (PM) and sudangrass (SG) 2005 


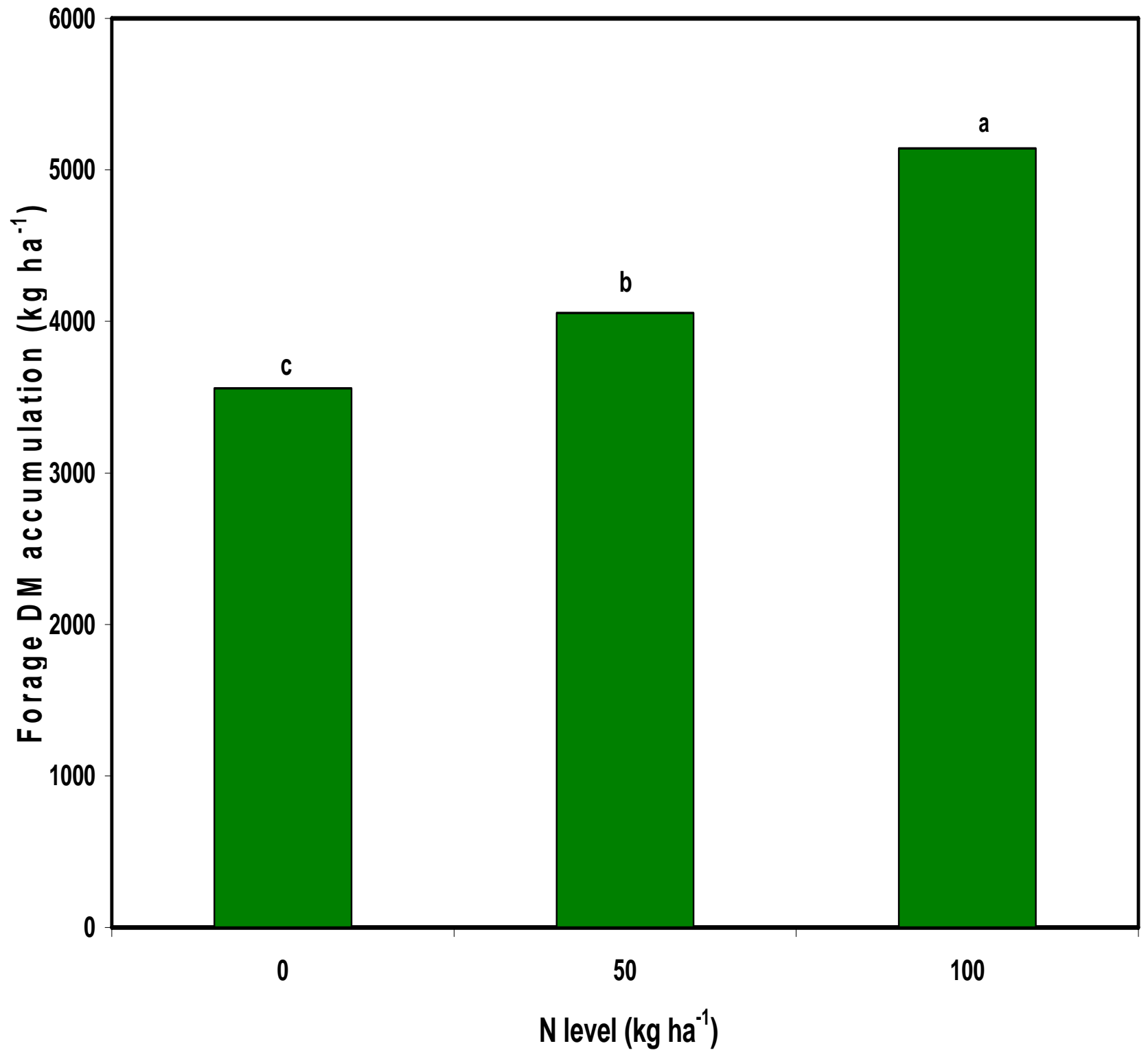

Figure 5. Effect of $\mathrm{N}$ on summer DM production across all species and years. Bars with the same letter do not differ at $\mathrm{P}<0.05$. Interactions between $\mathrm{N}$ and year and between $\mathrm{N}$ and species were not significant. 
Considering individual species (Figure 6), herbage mass of naturalized pasture numerically averaged $306 \mathrm{~kg} \mathrm{ha}^{-1}$ more with high than with low $\mathrm{N}$ and $573 \mathrm{~kg} \mathrm{ha}^{-1}$ more than unfertilized forage, but the differences were not statistically significant. Pearl millet that received high $\mathrm{N}$ averaged $958 \mathrm{~kg} \mathrm{ha}^{-1}$ DM more than that which received low $\mathrm{N}$ and $1588 \mathrm{~kg} \mathrm{ha}^{-1}$ more than the control. Sudangrass that received high $\mathrm{N}$ application produced $1407 \mathrm{~kg} \mathrm{ha}^{-1} \mathrm{DM}$ more than that which received low $\mathrm{N}$ and $1831 \mathrm{~kg} \mathrm{ha}^{-1} \mathrm{DM}$ more than control. The high $\mathrm{N}$ level in this experiment was based on the recommendation of Colyer et al. (1977) who concluded that cool-season naturalized forages perform optimally at $\mathrm{N}$ levels of $200 \mathrm{~kg} \mathrm{ha}^{-1}$ year $^{-1}$.

\section{Vegetation control}

For the two-year study period, pearl millet did not germinate following burning, instead the natural vegetation recovered. The forage accumulation of this natural vegetation after burning, in pearl millet seeded plots was higher in 2005 compared to 2004. Failure of pearl millet to germinate after burning can be attributed to competition from naturalized pasture, however, even after a second burning carried out in 2005 to minimize competition, the same effect was again observed. In contrast, pearl millet seeded after glyphosate application germinated in both 2004 and 2005. This shows that glyphosate is more effective in controlling vegetation before establishing forage. 


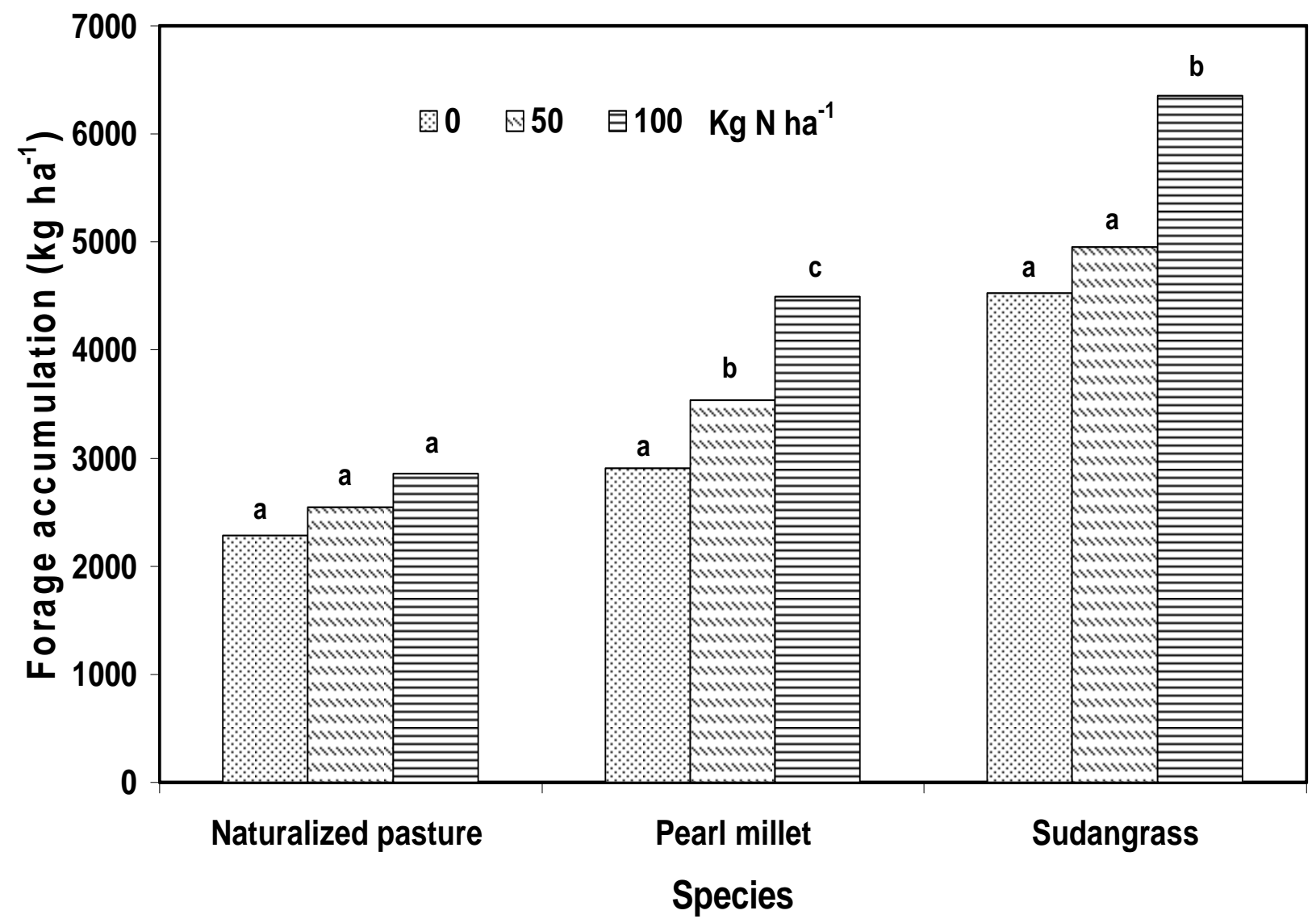

Figure 6. Effect of $\mathrm{N}$ level on summer forage DM production of naturalized pasture, pearl millet and sudangrass. Within species, bars with the same letter do not differ at $\mathrm{P}<0.05$. Interaction of species by year was not significant at $\mathrm{P}<$ 0.05 . 
These findings are in agreement with the study of Sanderson et al. (2004) who concluded that burning as a vegetation control method results in reduced yields compared to the use of glyphosate.

There was a significant three-way interaction between vegetation control, species, and year (Figure 7). Forage mass of naturalized pasture in pearl millet seeded plots after burning was higher in 2005 than 2004. Pearl millet seeded after glyphosate application produced higher forage mass in 2005 than 2004 . In contrast, forage mass of sudangrass after glyphosate application increased significantly in 2005 compared to 2004 , whereas after burning, it did not change (Figure 7). Glyphosate application increased DM production of both sudangrass and pearl millet compared to burning. In 2004, pearl millet seeded after glyphosate application produced $323 \mathrm{~kg} \mathrm{ha}^{-1}$ more than after burning. Similarly, sudangrass after glyphosate application produced $1857 \mathrm{~kg} \mathrm{ha}^{-1} \mathrm{DM}$ more than after burning. In 2005, pearl millet seeded after glyphosate application produced $837 \mathrm{~kg} \mathrm{ha}^{-1}$ more than after burning. Also, sudangrass after glyphosate application produced $4831 \mathrm{~kg} \mathrm{ha}^{-1}$ more than after burning. 


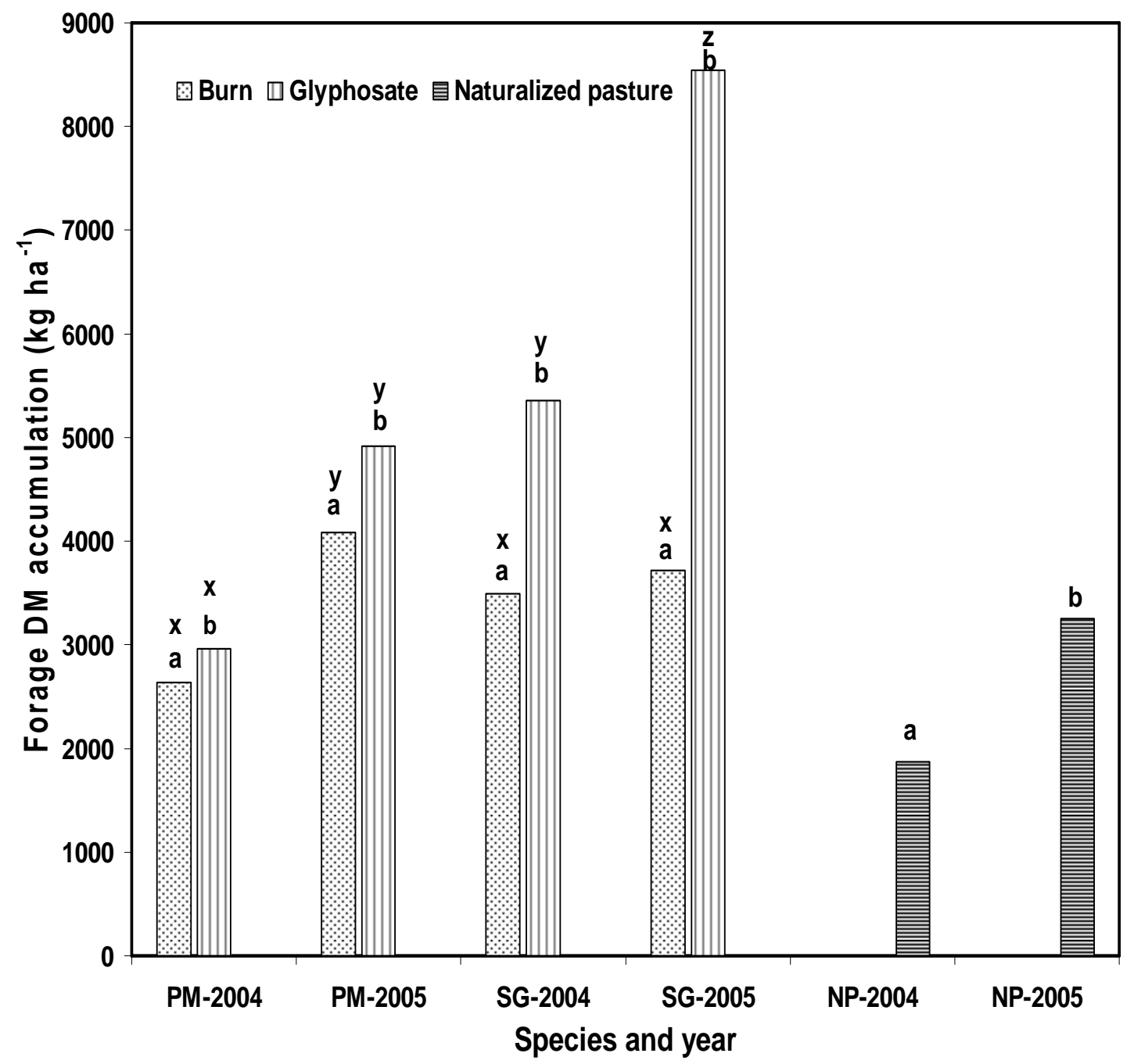

Figure 7. Effect of preplant vegetation control, species, and year on DM production of sudangrass (SG) and pearl millet (PM) compared to naturalized pasture (NP). Within each species and year, bars with the same letter $(a, b)$ are not significantly different at $P<0.05$. Within each preplant vegetation control method, bars with the same letter $(x, y, z)$ are not significantly different at $P<0.05$. Year by vegetation control by species interaction is significant at $P<0.001$. 
There was a significant two-way interaction $(P<0.001)$ between year and vegetation control. In 2004, forage established after glyphosate application produced $1090 \mathrm{~kg} \mathrm{ha}^{-1} \mathrm{DM}$ more than that after burning and $2277 \mathrm{~kg} \mathrm{ha}^{-1} \mathrm{DM}$ more than control (Figure 8). In 2005, forage established after glyphosate application produced $2835 \mathrm{~kg} \mathrm{ha}^{-1} \mathrm{DM}$ more than after burning and $3478 \mathrm{~kg} \mathrm{ha}^{-1}$ more than the control. In each method of vegetation control, forage mass produced in 2004 was lower than in 2005. Forage mass was $831 \mathrm{~kg} \mathrm{ha}^{-1}$ more after burning, $2576 \mathrm{~kg}$ more after glyphosate application, and $1385 \mathrm{~kg}$ more under naturalized pasture in 2005 than 2004 (Figure 8).

There was a significant interaction $(P<0.05)$ between method of vegetation control and $\mathrm{N}$ level (Figure 9). Forage mass after glyphosate application in unfertilized plots produced $1529 \mathrm{~kg} \mathrm{ha}^{-1}$ more than after burning and $2201 \mathrm{~kg} \mathrm{ha}^{-1}$ more than the control. Forage mass after glyphosate application with low $\mathrm{N}$ produced $1479 \mathrm{~kg} \mathrm{ha}^{-1}$ more than after burning and 2435 $\mathrm{kg} \mathrm{ha}^{-1}$ more than the control. Forage mass after glyphosate application with high $\mathrm{N}$ produced $2878 \mathrm{~kg} \mathrm{ha}^{-1}$ more than after burning and $4012 \mathrm{~kg} \mathrm{ha}^{-1}$ more than the control. 


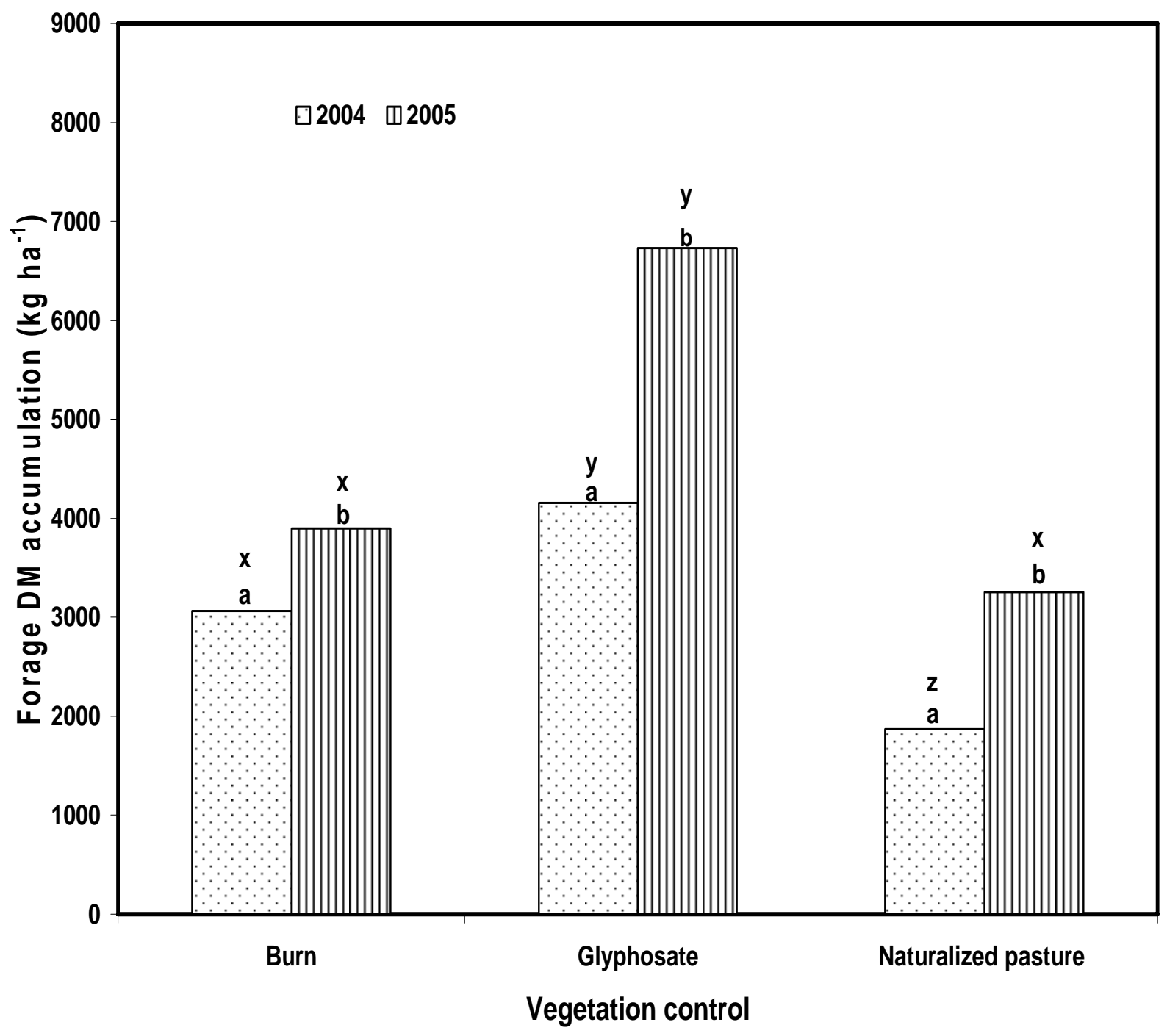

Figure 8. Effect of preplant vegetation control and year on summer DM production. Within each preplant vegetation control method, bars with the same letter $(a, b)$ are not significantly different $(P<0.05)$. Within each year, bars with the same letter $(x, y, z)$ are not significantly different $(P<0.05)$. The vegetation control by year interaction is significant $(P<0.0001)$. 


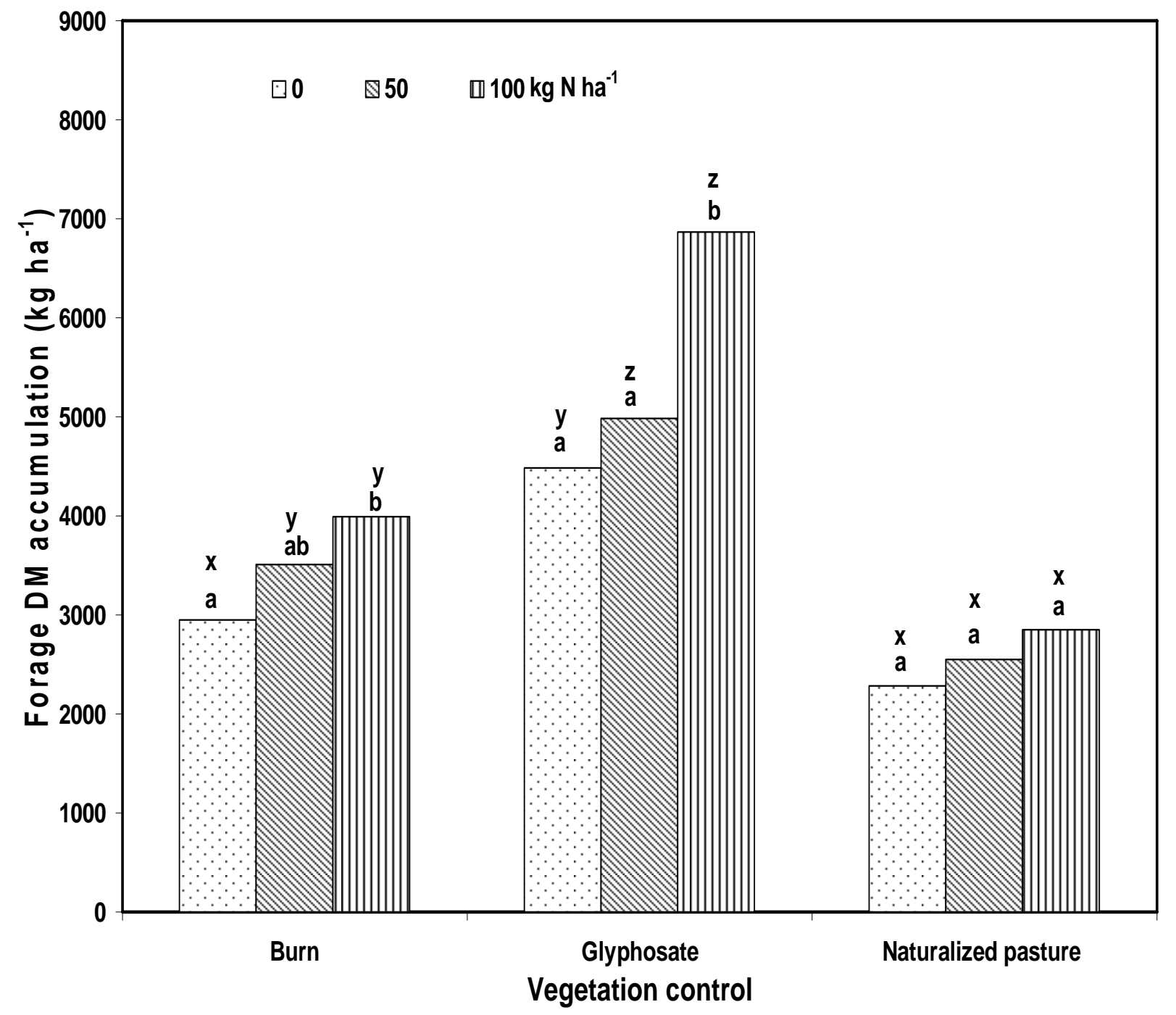

Figure 9. Effect of preplant vegetation control and $\mathrm{N}$ level on summer DM production. Within each vegetation control method, bars with the same letter (a, $b, c)$ are not significantly different. Within each nitrogen level, bars with same letter $(x, y, z)$ are not significantly different $(P<0.05)$. The $N$ by vegetation control interaction is significant at $P<0.001)$. 


\section{Physiological Maturity}

Morphological maturity of pearl millet and sudangrass was compared (Table 2). Sudangrass was more mature than pearl millet, at the time of harvesting. Most of the tillers of sudangrass were close to the reproductive stage, whereas those of pearl millet were in the early vegetative stage.

Nitrogen application significantly increased $(P<0.01)$ morphological maturity of both grasses (Table 2). An increase in maturity of sudangrass with higher levels of $\mathrm{N}$ application was also reported by Jung et al. (1964). Method of vegetation control used to establish sudangrass and pearl millet had a significant effect $(P<0.01)$ on mean stage by weight of forage at harvest (Table 2). Glyphosate reduced competition which in turn increased growth and maturity of both sudangrass and pearl millet. In contrast, burning resulted in increased competition reducing the physiological development of both species.

\section{Fall period}

\section{Species}

There was a significant year by fall species interaction for forage DM accumulation (Figure 10). In 2005, the mixture of annual ryegrass and turnip produced more than in 2004, while DM production for triticale and naturalized pasture was not significantly different for the two years. In both years DM production from the mixture and naturalized pasture were not different but higher than triticale. There was no significant year effect on DM production from triticale and naturalized pasture. In 2004, forage accumulation from naturalized pasture was not significantly different from that of the mixture of annual ryegrass and turnip but higher than triticale. 
Table 2. The effect of species, $\mathrm{N}$ level and preplant vegetation control on morphological maturity of sudangrass and pearl millet

\begin{tabular}{|c|c|}
\hline Treatments & Mean stage weight \\
\hline \multicolumn{2}{|l|}{ Species } \\
\hline Pearl millet & $2.17 \mathrm{a}$ \\
\hline Sudangrass & $2.86 \mathrm{~b}$ \\
\hline \multicolumn{2}{|l|}{ N level } \\
\hline \multicolumn{2}{|l|}{$\mathrm{kg} \mathrm{N} \mathrm{ha}^{-1}$} \\
\hline 0 & $2.30 \mathrm{a}$ \\
\hline 50 & $2.41 \mathrm{~b}$ \\
\hline 100 & $2.54 \mathrm{c}$ \\
\hline \multicolumn{2}{|c|}{ Preplant vegetation control } \\
\hline Burning & $2.32 \mathrm{a}$ \\
\hline Glyphosate & $2.51 \mathrm{~b}$ \\
\hline
\end{tabular}




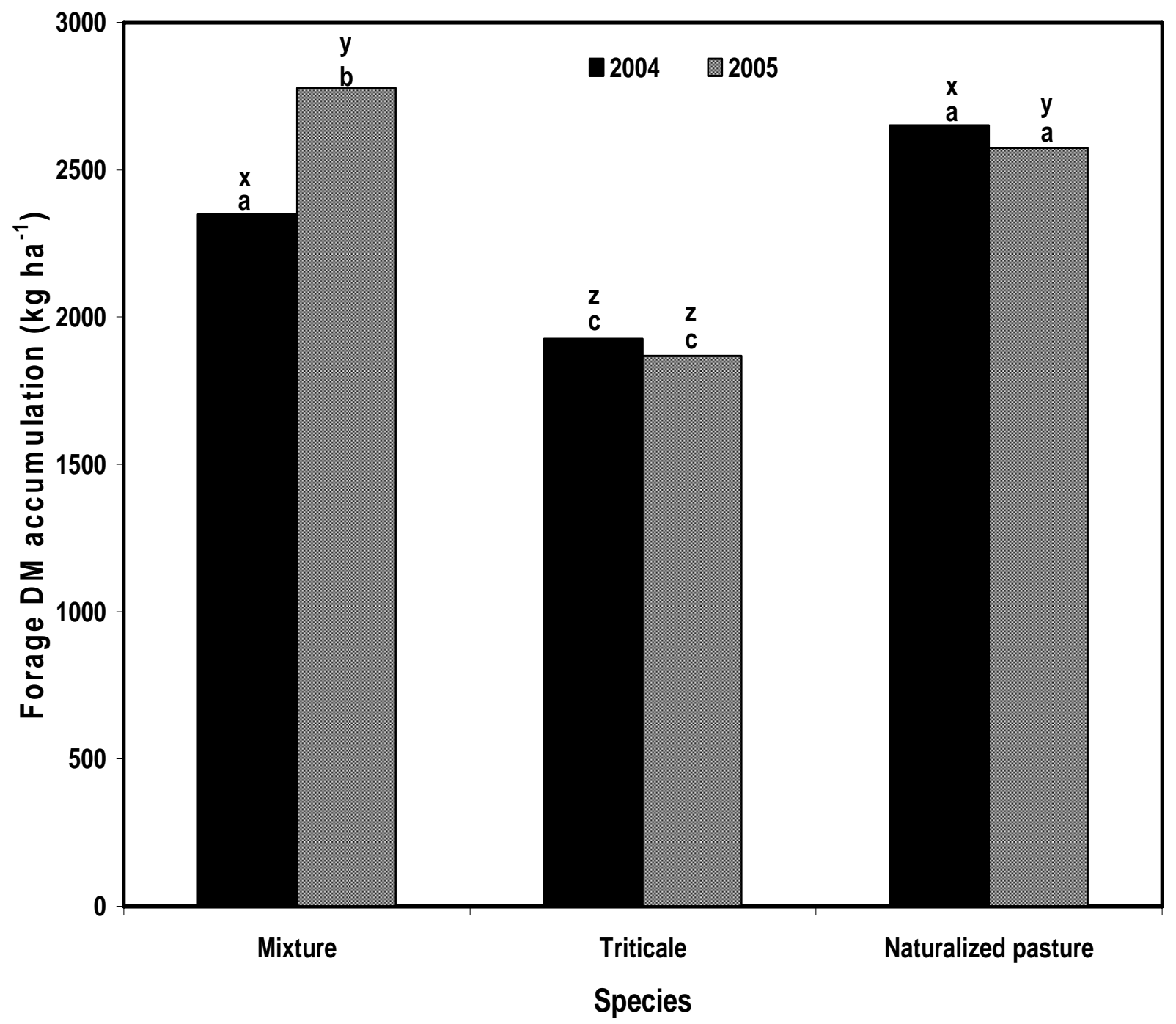

Figure 10. Effect of species on fall DM production. Within each species, bars with the same letter $(a, b, c)$ are not significantly different at $P<0.05$. Within each year bars with the same letter $(x, y, z)$ are not significantly different at $P<0.05$. Year by species interaction is significant at $\mathrm{P}<0.01$. 
Naturalized pasture (2650 kg ha-1) accumulated $302 \mathrm{~kg} \mathrm{ha}^{-1}$ more forage than the mixture $\left(2347 \mathrm{~kg} \mathrm{ha}^{-1}\right)$ and $712 \mathrm{~kg} \mathrm{ha}^{-1}$ more than triticale $\left(1925 \mathrm{~kg} \mathrm{ha}^{-1}\right)$. The mixture of annual ryegrass and turnip accumulated $423 \mathrm{~kg} \mathrm{ha}^{-1}$ more than the triticale.

In 2005, the mixture of annual ryegrass and turnip produced $2778 \mathrm{~kg} \mathrm{ha}^{-1}$ forage mass, numerically higher than naturalized pasture $\left(2574 \mathrm{~kg} \mathrm{ha}^{-1}\right)$, but the difference $\left(204 \mathrm{~kg} \mathrm{ha}^{-1}\right)$ was not significant. The naturalized pasture and the mixture of annual ryegrass and turnip produced significantly higher biomass than triticale (1868 $\left.\mathrm{kg} \mathrm{ha}^{-1}\right)$. The mixture of annual ryegrass and turnip accumulated $910 \mathrm{~kg}$ and naturalized pasture $706 \mathrm{~kg} \mathrm{ha}^{-1}$ more than triticale. The higher biomass of the mixture of annual ryegrass and turnip than triticale is in agreement with Guillard et al. (1988) who reported that brassica produced greater yields under cool conditions and relatively short days than stockpiled pastures. Stockpiling for the naturalized pasture commenced on August $9^{\text {th }}$ in the first year and on July $25^{\text {th }}$ in the second year. During the time of stockpiling, the temperatures were still suitable for growth. It is a common practice for beef producers in this region to stockpile early enough so that significant accumulation can occur. 


\section{Vegetation control}

Burning and use of glyphosate for controlling vegetation before establishing annual forages in the fall had a significant effect on forage accumulation (Figure 11). There was an interaction between vegetation control and fall species $(P<0.01)$. The mixture of turnip and ryegrass seeded after glyphosate application produced significantly more DM than when seeded after burning and was similar in yield to naturalized vegetation. The DM accumulation of triticale established after burning was not significantly different from that established after glyphosate application but it was significantly lower than the naturalized pasture. However, this lack of effect of method of establishment on triticale production was because other vegetation contributed to the forage mass after burning, whereas after glyphosate application, only triticale was present. Higher DM production was expected from the mixture of turnip and ryegrass seeded after glyphosate application compared to after burning. As expected glyphosate application eliminated competition and turnip and ryegrass production increased. The use of glyphosate resulted in total killing of perennial grasses and allowed the planted annuals to contribute all of the DM. In contrast, burning killed only the top growth of the existing vegetation; it recovered quickly and competed with the planted annuals. In the burnt plots the seeded annuals did not perform as well as the naturalized forages. 


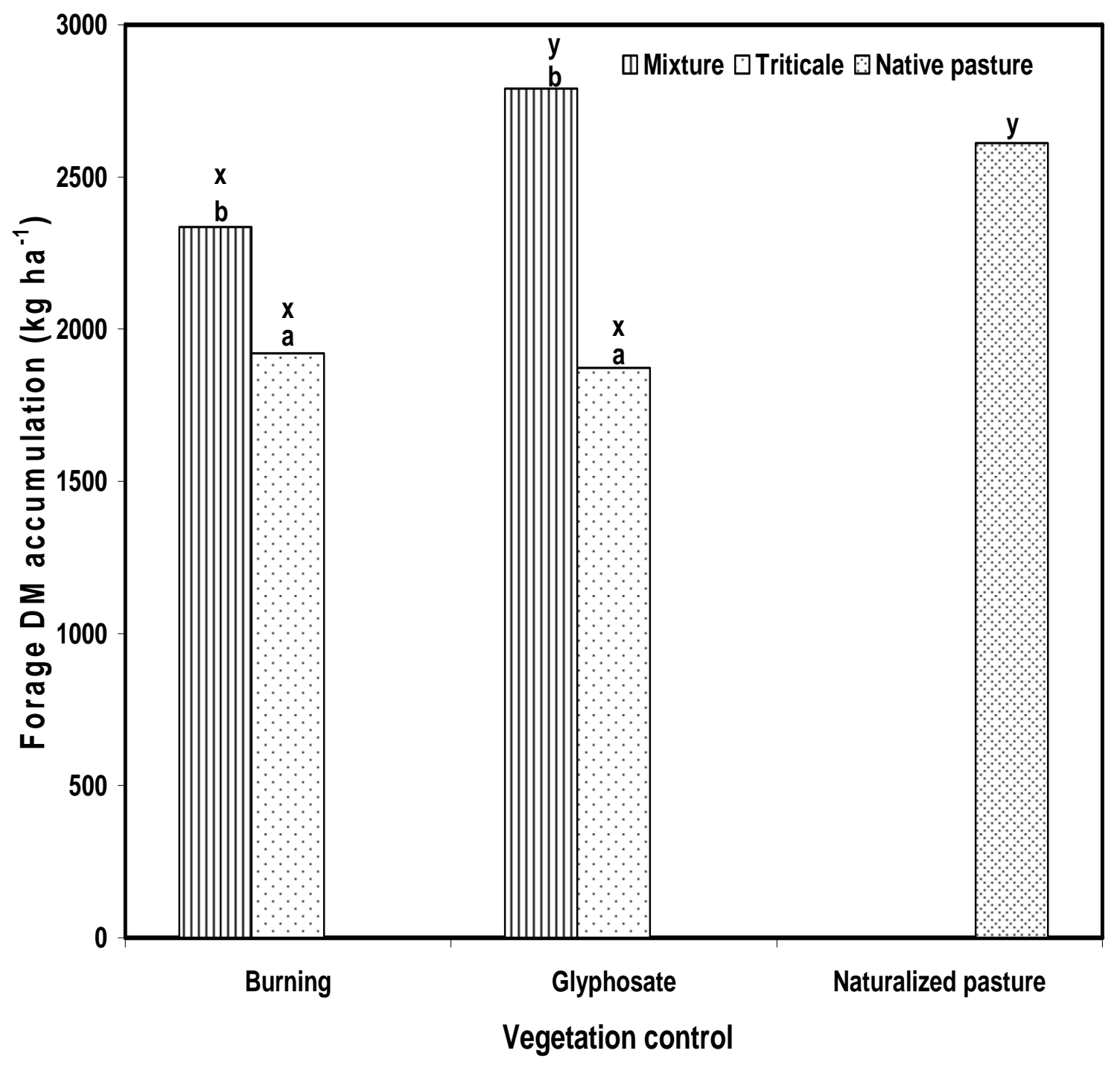

Figure 11. Effect of vegetation control on fall DM production of the mixture of annual ryegrass and turnip, and triticale compared to naturalized pasture. Within each method of preplant vegetation control, bars with the same letter $(a, b)$ are not significantly different at $P<0.05$. Within each species bars with the same letter $(\mathrm{x}, \mathrm{y})$ are not significantly different at $\mathrm{P}<0.05$. 


\section{Nitrogen fertilization}

For fall forage production, there was no significant interaction between year and $\mathrm{N}$ level, or between $\mathrm{N}$ level and species, or $\mathrm{N}$ and vegetation control. The treatments that received the high level of $\mathrm{N}\left(100 \mathrm{~kg} \mathrm{ha}^{-1}\right)$ produced $489 \mathrm{~kg}$ $\mathrm{ha}^{-1}$ more forage than the treatments that received the low level $\left(50 \mathrm{~kg} \mathrm{ha}^{-1}\right)$ and $1199 \mathrm{~kg} \mathrm{ha}^{-1}$ more than the unfertilized treatments. The treatments that received the low level of $N\left(50 \mathrm{~kg} \mathrm{ha}^{-1}\right)$ had $710 \mathrm{~kg} \mathrm{ha}^{-1}$ more forage than unfertilized treatments (Figure 12).

\section{Days after seeding}

Forage DM production of the mixture of turnip and annual ryegrass, triticale, and naturalized pasture with increasing days after seeding is presented in Figure 13. At day 31 in 2004 and day 44 in 2005, the naturalized pasture had more biomass than triticale and the mixture of annual ryegrass and turnip. The reason for high biomass in the early part of the growing period in the naturalized pastures treatment is because it was not subjected to preplant vegetation control. Triticale and the mixture of annual ryegrass and turnip were seeded and growth occurred from seed which took time to first develop and grow. For naturalized pasture, stockpiling started earlier than the time when annual forages were established. Triticale was slower in reaching a similar level of DM accumulation as naturalized pasture and the mixture in 2004. In 2005 triticale again took longer to accumulate DM and never reached the production of the other two treatments. 


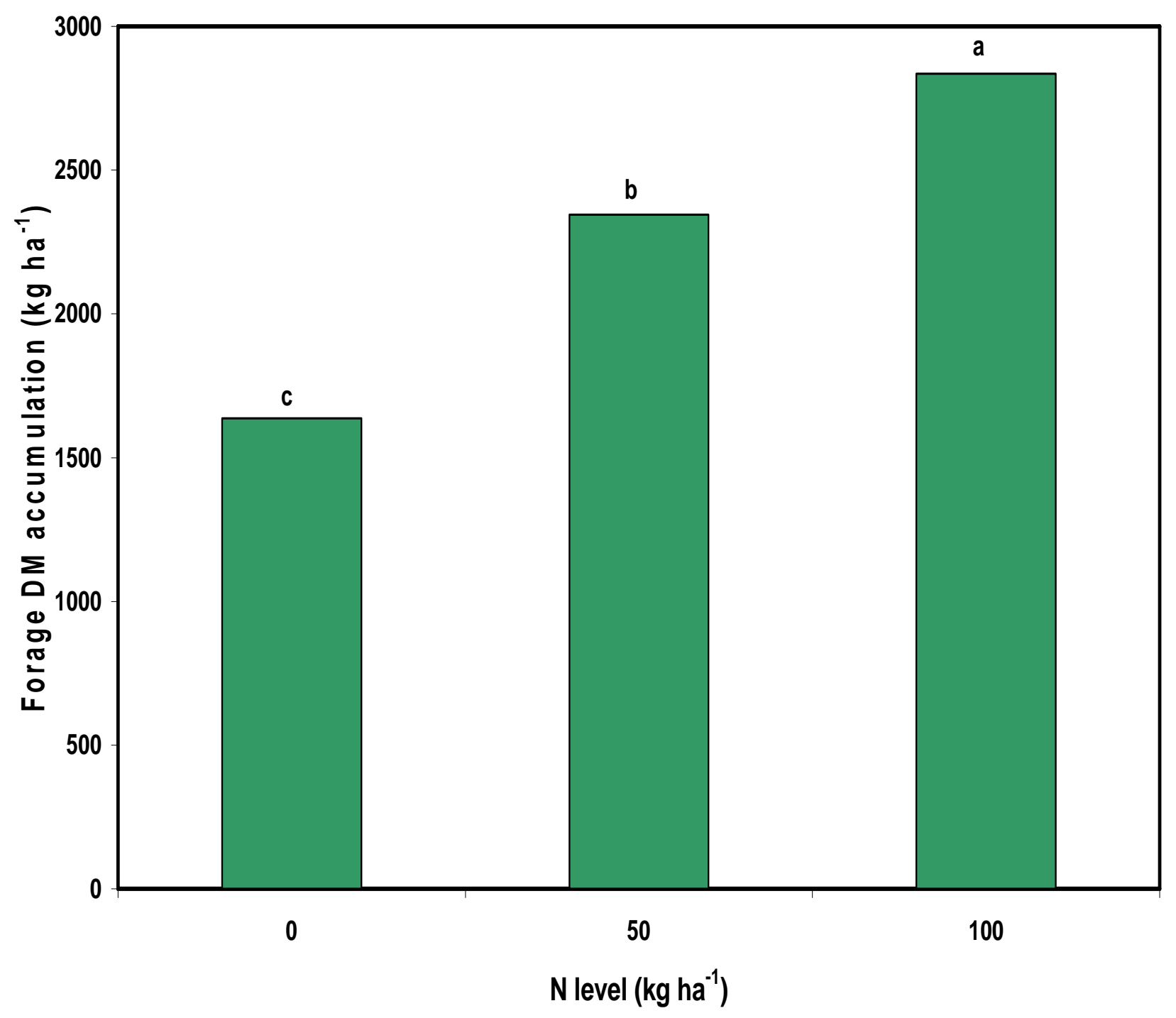

Figure 12. Effect of $\mathrm{N}$ application on fall DM production. Bars with the same letter are not significantly different at $P<0.05$. 

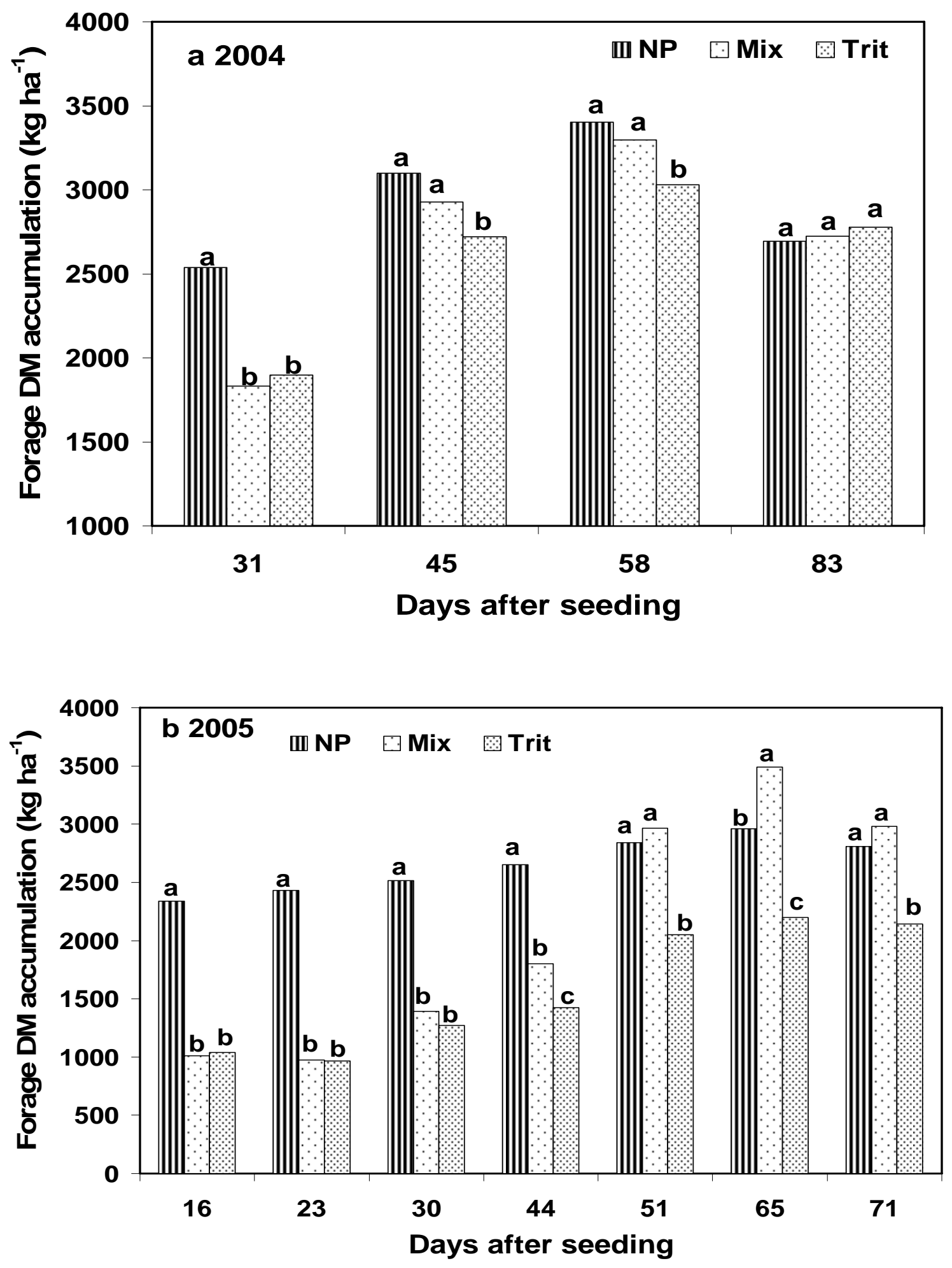

Figure 13. Effect of days after seeding (DAS) on forage DM accumulation of the mixture (Mix) of annual ryegrass and turnip, triticale (Trit) and naturalized pasture (NP) during the fall of (a) 2004 and (b) 2005. Within DAS, bars with the same letter are not significantly different at $P<0.05$. 


\section{Turnip production}

Use of glyphosate as a preplant vegetation control method before establishing turnip doubled forage mass compared to when it was established after burning (Figure 14). The reason for higher forage mass from turnip established after glyphosate was because glyphosate was very effective in killing the sod leaving the turnip and annual ryegrass as the sole crop. Turnip has broad leaves that can capture more light than annual ryegrass. It also grew at a faster rate and, therefore, out performed annual ryegrass.

Year by $\mathrm{N}$ level interaction was significant at $\mathrm{P}<0.05$. There was a progressive increase in DM production as $\mathrm{N}$ level increased in 2004 but not in 2005 (Figure 15). In 2005, forage mass from plots that received $50 \mathrm{~kg} \mathrm{~N} \mathrm{ha}^{-1}$ was similar to those that received $100 \mathrm{~kg} \mathrm{~N} \mathrm{ha}^{-1}$. The reason for lack of DM response when $\mathrm{N}$ level was increased from $50 \mathrm{~kg} \mathrm{ha}^{-1}$ to $100 \mathrm{~kg} \mathrm{ha}^{-1}$ in 2005 can be attributed to high initial $\mathrm{N}$ fertility. These findings are in agreement with reports of Monks et al. (1997) who stated that cover crops did not respond to additional application of $\mathrm{N}$ on soils with high initial $\mathrm{N}$ fertility. 


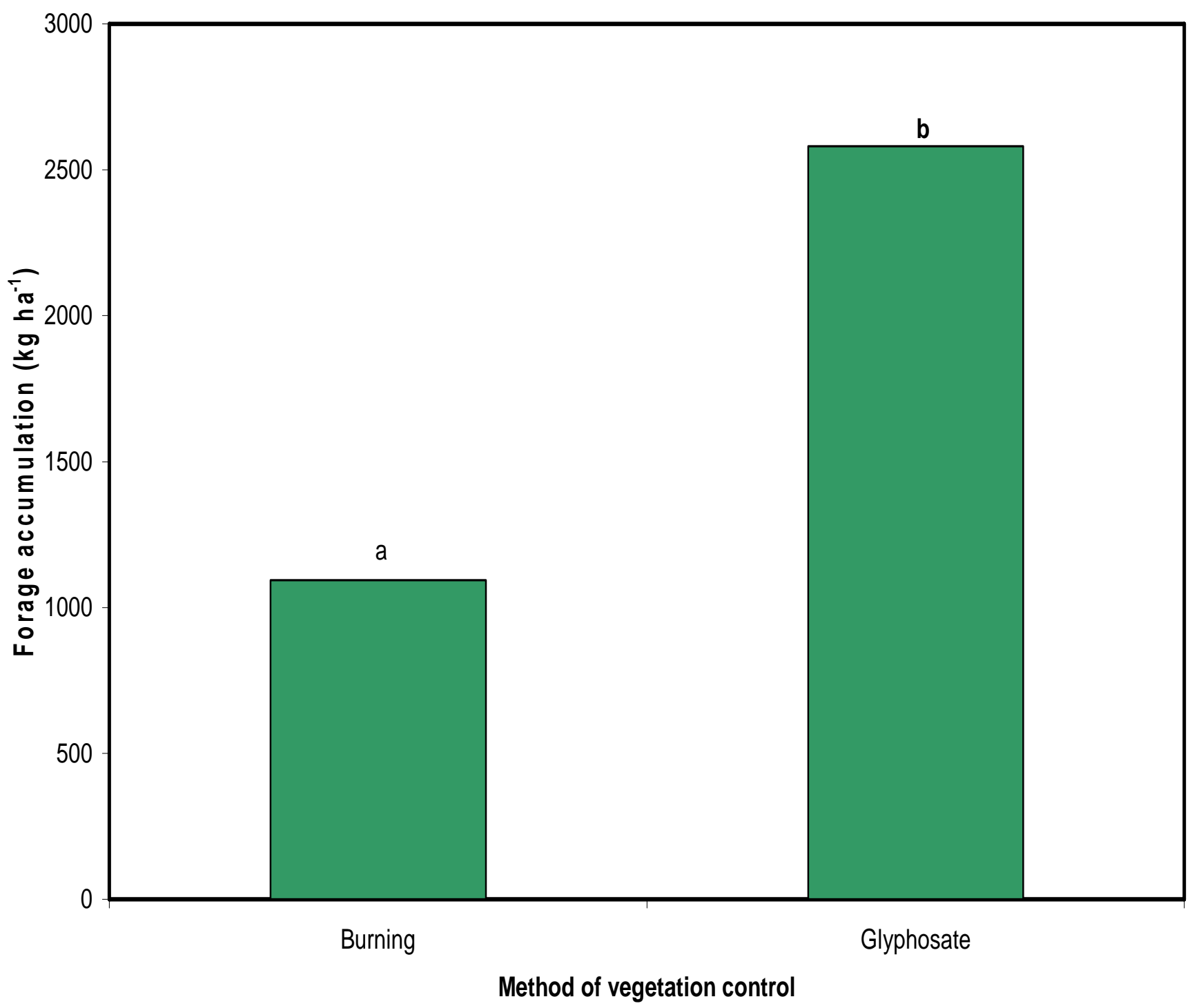

Figure 14. Effect of preplant method of vegetation control on DM production of turnip in fall. Bars with the same letter are not significantly different at $P<0.05$. There was no year by vegetation control interaction. 


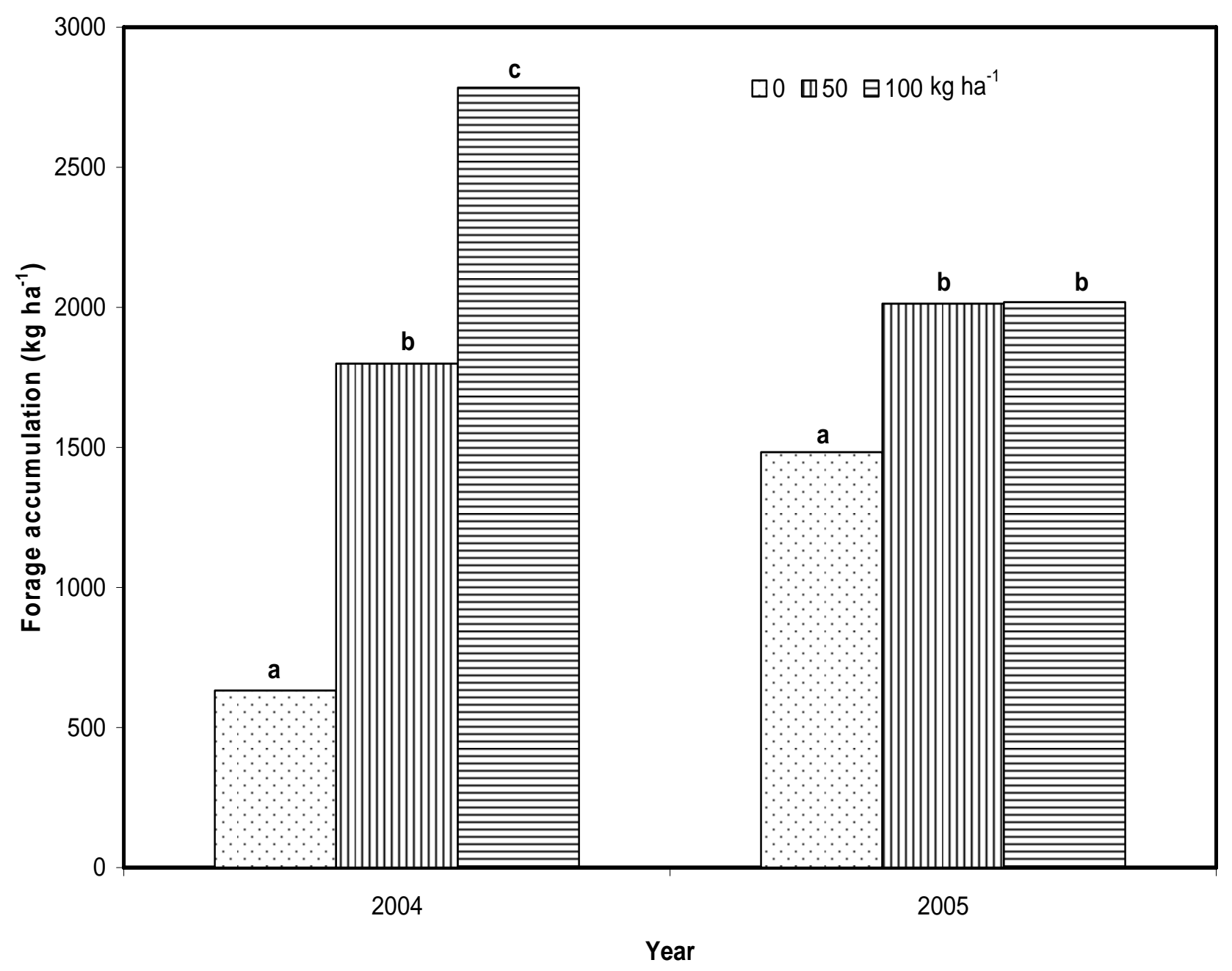

Figure 15. Effect of $\mathrm{N}$ level and year on DM production of turnip in fall. Bars with the same letter within each year are not significantly different at $P<0.05$. Year by $\mathrm{N}$ level interaction was significant at $\mathrm{P}<0.05$. 


\section{Spring forage accumulation of fall crop}

\section{Species}

Residual forage accumulation in spring 2006 of fall annual species is reported here. The spring residual for the 2004 seeding was incomplete because spring triticale was planted in 2004 instead of winter triticale. The spring triticale flowered in November. Dry matter production of the triticale and the mixture of annual ryegrass and turnip were not different but were higher than naturalized pasture (Figure 16). The established annual forages started to grow earlier in spring than naturalized pasture. Spring forage mass of annual species established in fall was higher when harvested in spring than when harvested in fall. After completion of the study animals were allowed to graze free choice. It was then observed that animals preferred the ryegrass turnip mixture to triticale or naturalized pasture. This result suggests that these annual crops planted in fall can be harvested twice, in November and spring.

\section{Preplant vegetation control}

Species established after glyphosate application produced significantly more residual forage mass in spring than those seeded after burning and naturalized pasture (Figure 17). Glyphosate killed perennial plants in fall and reduced competition to the established annual forages. In spring, annual forages grew much faster than the naturalized pasture. 


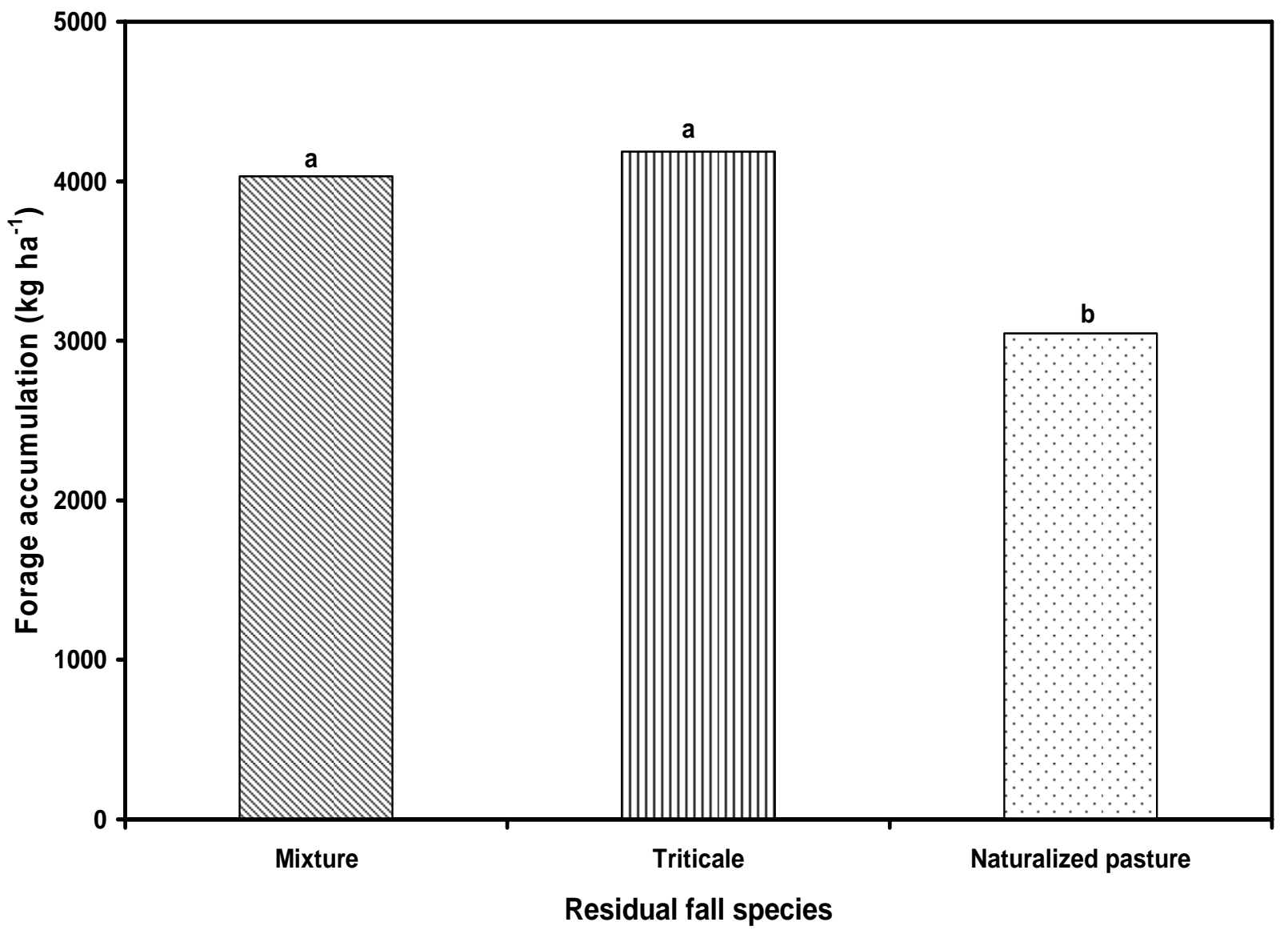

Figure 16. The effect of fall species (mixture of annual ryegrass and turnip, triticale and naturalized pasture) harvested in spring (5/4/06) on forage accumulation. Bars with the same letter are not significantly different at $\mathrm{P}<0.05$. Species by vegetation control or species by nitrogen interactions were not significant. 


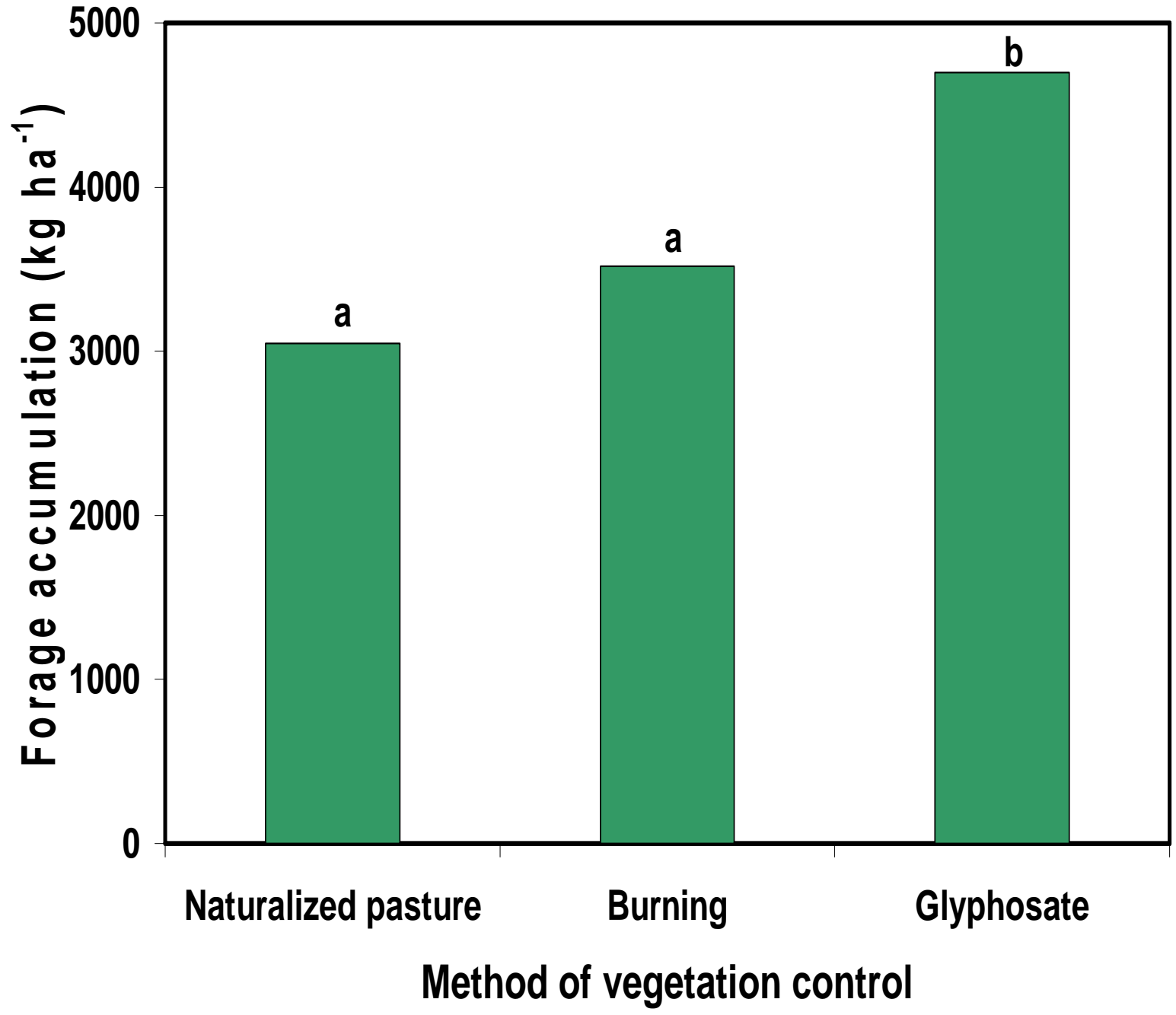

Figure 17. The effect of method of preplant vegetation control on forage accumulation of the fall planted crop harvested in spring. Bars with the same letter are not significantly different at $P<0.05$. There were no vegetation control by species or by nitrogen level interactions. 


\section{$\mathbf{N}$ levels}

Nitrogen at either 50 or $100 \mathrm{~kg} \mathrm{ha}^{-1}$ applied in fall increased accumulation of residual DM in spring (Figure 18). The $100 \mathrm{~kg} \mathrm{~N}^{-1}$ application did not produce significantly more forage than the $50 \mathrm{~kg} \mathrm{~N} \mathrm{ha}^{-1}$ because during spring the main source of $\mathrm{N}$ came from mineralization of organic residues.

\section{Nutritive value}

\section{Species}

Summer species by year interactions were significant for TDN, ADF and NDF concentrations but not for CP concentration. In 2004, sudangrass had a lower TDN concentration and higher ADF and NDF concentrations than pearl millet and naturalized pasture (Figures 19 and 20). In contrast, in 2005, sudangrass had higher TDN, ADF and NDF concentrations than naturalized pasture and pearl millet. The reason for this trend can be attributed to weather conditions (Figure 1). In 2004, the weather was wet and cool during summer, whereas in 2005 was warmer and drier. The warmer weather contributed to a higher accumulation of sugars, hence a higher TDN concentration. 


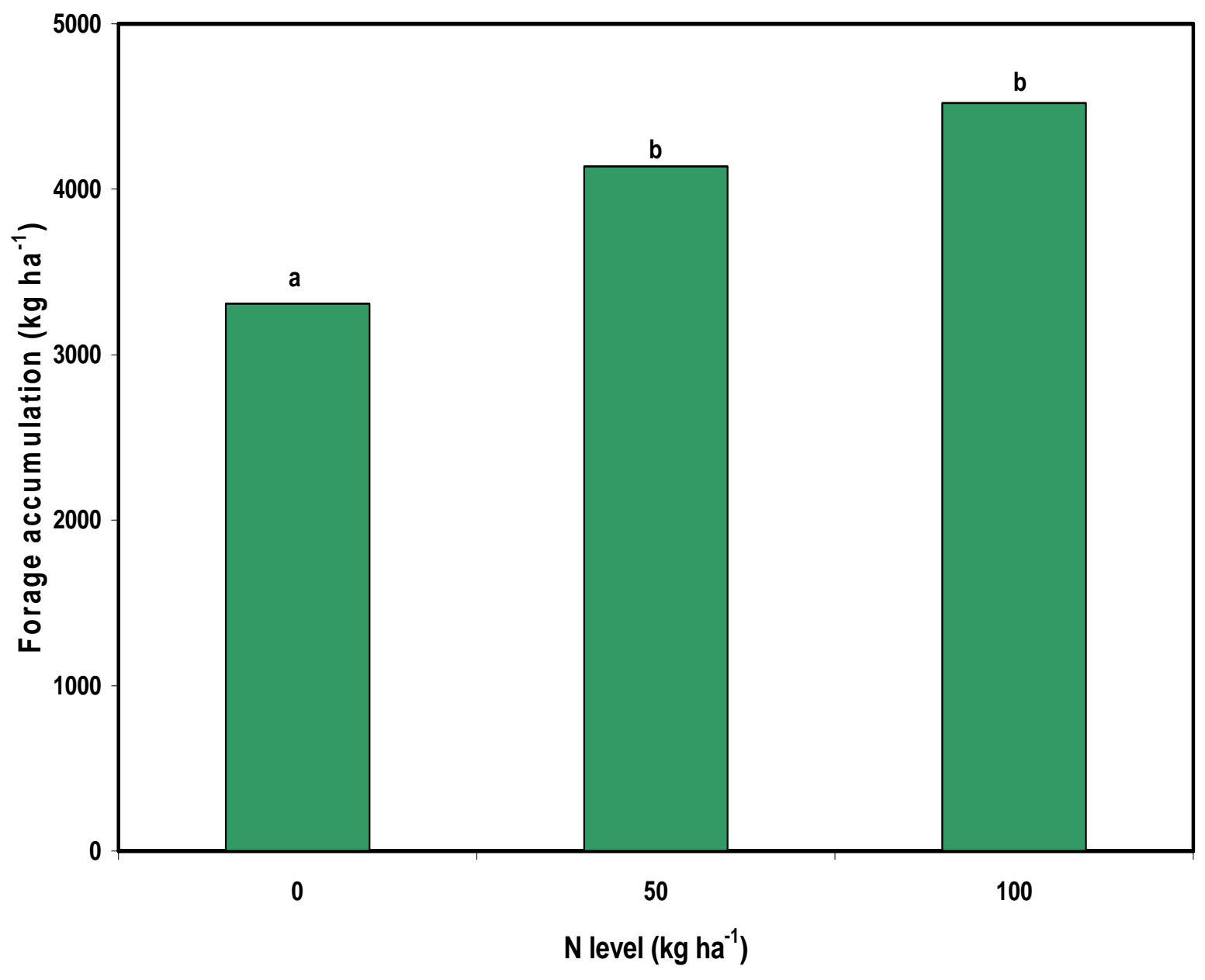

Figure 18. The effect of level of $\mathrm{N}$ on forage accumulation of fall planted crops that were harvested in spring. Bars with the same letters are not significantly different at $\mathrm{P}<0.05$. There were no significant interactions between $\mathrm{N}$ and species or between $\mathrm{N}$ and method of vegetation control. 


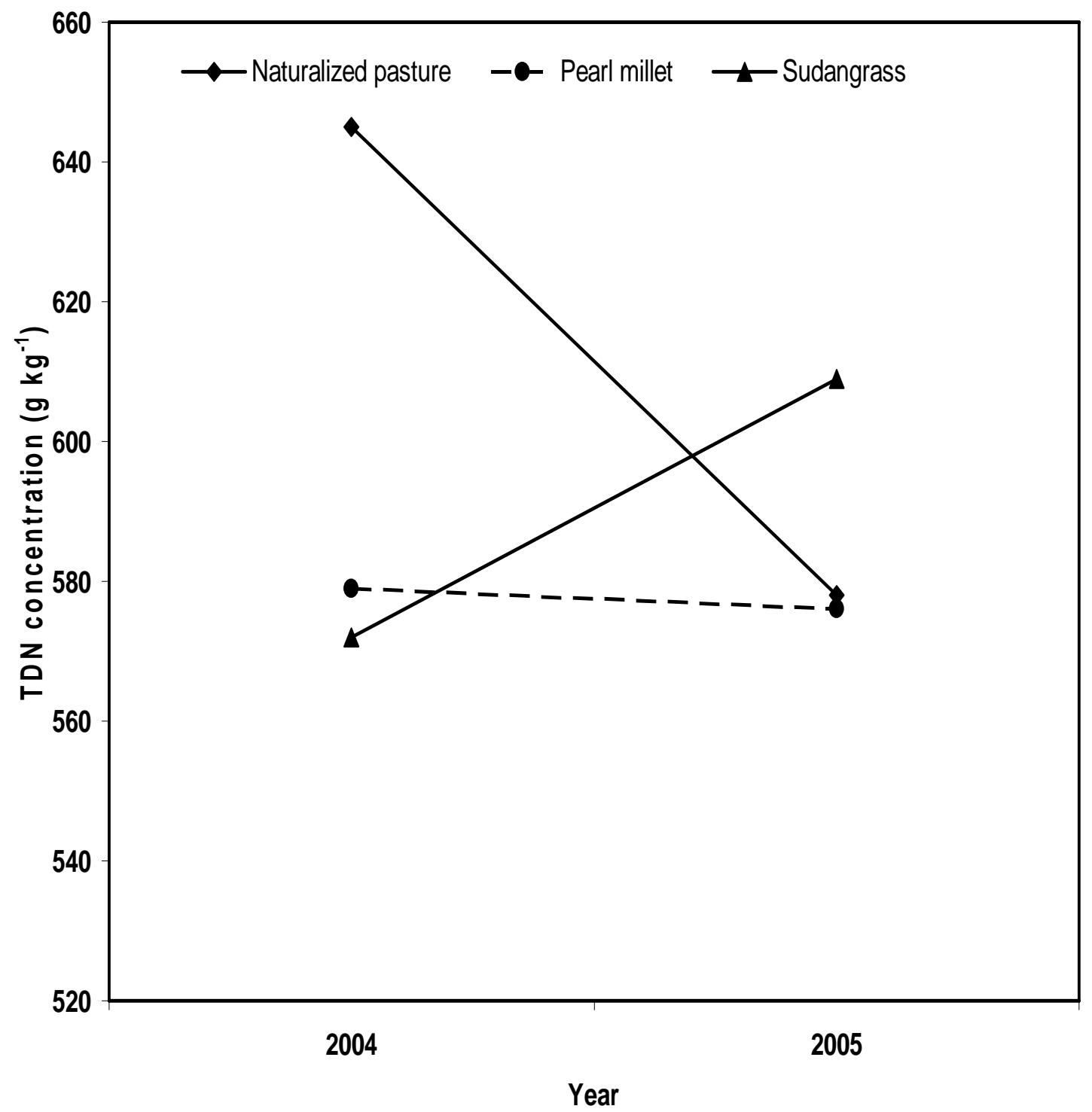

Figure 19. Effect of summer species and year on TDN concentrations. Summer species by year interaction is significant at $P<0.05$. 

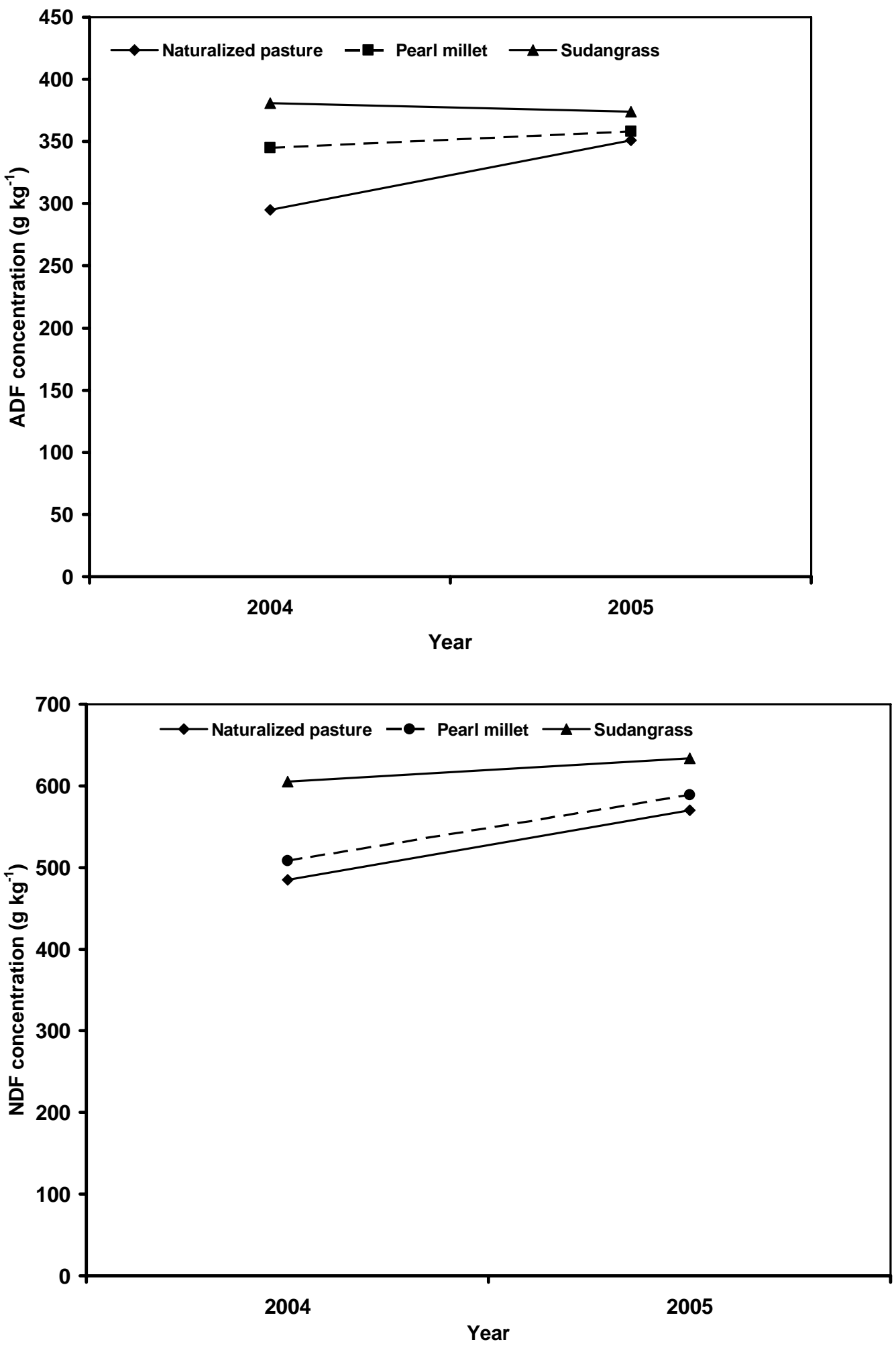

Figure 20. Effect of summer species and year on ADF and NDF concentrations. Summer species by year interaction is significant at $P<0.05$. 
Naturalized pasture, composed of Kentucky bluegrass, tall fescue, orchardgrass and clovers, tends to be mature with deteriorating quality during warm and dry environmental conditions. Quality of sudangrass, a warm season forage, increases as temperature increases. For some unexplained reasons, the TDN concentration of pearl millet in 2004 was same as 2005 . These results are in agreement with Lopez-Dominguez et al., 2001, who reported that forage quality is affected by plant species and environmental factors. The significance of this phenomenon in animal production is that warm-season annual forages are of high quality and utilized well during the time when environmental conditions are hot and dry. In 2004, low NDF and ADF concentrations for pearl millet and naturalized pasture indicate that more of these forages would potentially be consumed and digested by the animal compared to sudangrass. Sudangrass during summer had significantly lower CP concentration (Table 3) than pearl millet and naturalized pasture. The higher $\mathrm{CP}$ concentration in pearl millet than sudangrass is in agreement with the report of Clark et al. (1965). However, the CP concentration of both sudangrass and pearl millet is lower than that reported by Clark et al. The low CP concentration in sudangrass can be attributed to its high forage accumulation with forage DM diluting CP.

Fall species by year interactions were significant for ADF and NDF concentrations (Figure 21). In 2004, the fiber content of triticale was close to naturalized pasture because during that year spring triticale was planted, and it flowered at harvest. The CP, TDN, ADF and TDN concentrations of triticale and 
Table 3. Crude protein, ADF, NDF and TDN concentrations of pearl millet, sudangrass and naturalized pasture.

\begin{tabular}{lllll}
\hline Species & CP & ADF & NDF & TDN \\
\hline & $--\cdot------$ \\
Pearl millet & $134 b$ & $352 b$ & $549 b$ & $578 b$ \\
Sudangrass & $97 \mathrm{c}$ & $377 \mathrm{c}$ & $619 \mathrm{c}$ & $590 \mathrm{c}$ \\
Naturalized pasture & $168 \mathrm{a}$ & $324 \mathrm{a}$ & $527 \mathrm{a}$ & $612 \mathrm{a}$ \\
\hline
\end{tabular}

Within summer species, columns with the same letter are not significantly different at $\mathrm{P}<0.05$. 

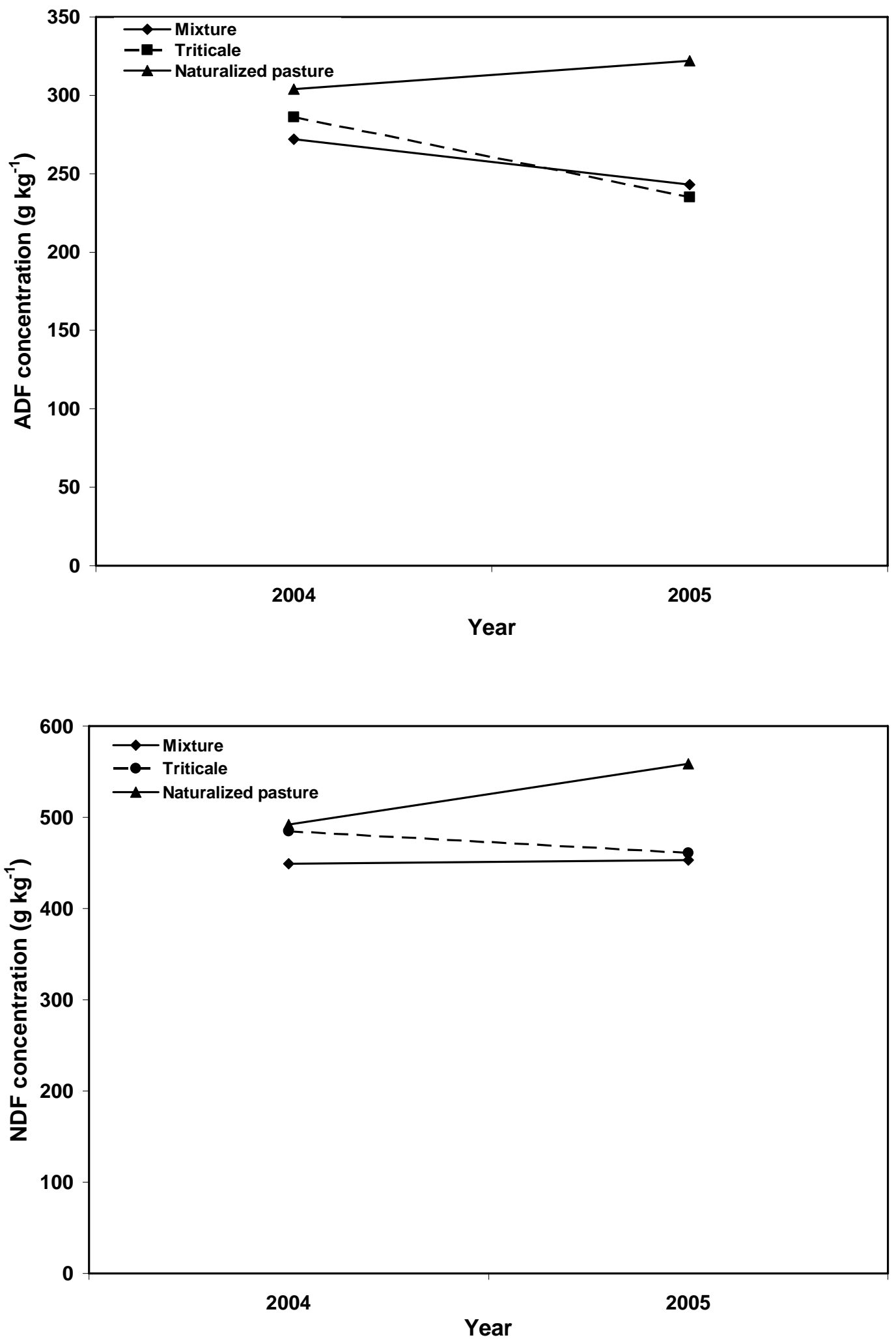

Figure 21. Effect of fall species and year on ADF and NDF concentrations. Fall species by year interaction is significant at $P<0.05$. 
the mixture of annual ryegrass and turnip were not different from each other (Table 4). The triticale and the mixture of annual ryegrass and turnip had higher $\mathrm{CP}$ and TDN concentrations and lower ADF and NDF concentrations than naturalized pasture. The higher CP and TDN concentrations and lower ADF and NDF concentrations of triticale and the mixture of annual ryegrass and turnip indicate that they are of higher quality than naturalized pasture.

\section{Vegetation Control}

The summer species for which a comparison of effect of vegetation control on nutritive value can be made was sudangrass. Pearl millet established after burning failed to germinate and develop. There was a year by preplant vegetation control method interaction for $\mathrm{CP}$ and TDN concentrations (Figure 22). The crude protein concentration of sudangrass established after burning was higher in 2005 than in 2004. In contrast, the CP concentration of sudangrass established after glyphosate application was lower in 2005 than in 2004. The lower CP concentration of sudangrass established after glyphosate application in 2004 than in 2005 can be attributed to increased forage mass in 2005. Sudangrass established after glyphosate had a lower TDN concentration in 2004 than in 2005 while after burning its TDN concentration was lower in 2005 than 2004. Herbage on plots established after burning had a higher CP concentration and lower ADF and NDF concentration than those established after glyphosate (Table 5). These differences in nutrient composition could be due to the amount of weeds and legume present. Forage from those plots established after burning was mainly a mixture of naturalized pasture and 
Table 4. Effect of fall species on CP, ADF, NDF and TDN concentrations.

\begin{tabular}{|c|c|c|c|c|}
\hline Fall Species & $\mathrm{CP}$ & ADF & NDF & TDN \\
\hline Mixture $^{1}$ & $191 a$ & $257 a$ & $451 a$ & $646 a$ \\
\hline Triticale & $186 a$ & $260 a$ & $473 a$ & $650 a$ \\
\hline Naturalized pasture & $162 \mathrm{~b}$ & $313 b$ & $525 b$ & $616 \mathrm{~b}$ \\
\hline
\end{tabular}

Within fall species, columns with the same letter are not significantly different at $P<0.05$. Fall species by year interaction is significant at $P<0.05$ for ADF and NDF.

${ }^{1}$ Turnip and annual ryegrass

Table 5. Effect of method of preplant vegetation control on CP, ADF, NDF and TDN concentrations of sudangrass.

\begin{tabular}{lllll}
\hline Vegetation control & CP & ADF & NDF & TDN \\
\hline Burning & $126 \mathrm{a}$ & $369 \mathrm{a}$ & $593 \mathrm{a}$ & $577 \mathrm{a}$ \\
Glyphosate & $97 \mathrm{~b}$ & $377 \mathrm{~b}$ & $619 \mathrm{~b}$ & $590 \mathrm{~b}$ \\
\hline
\end{tabular}

Within vegetation control method, columns with the same letter are not significantly different at $P<0.05$. Vegetation control by year interaction is significant for CP and TDN $(P<0.05)$. 

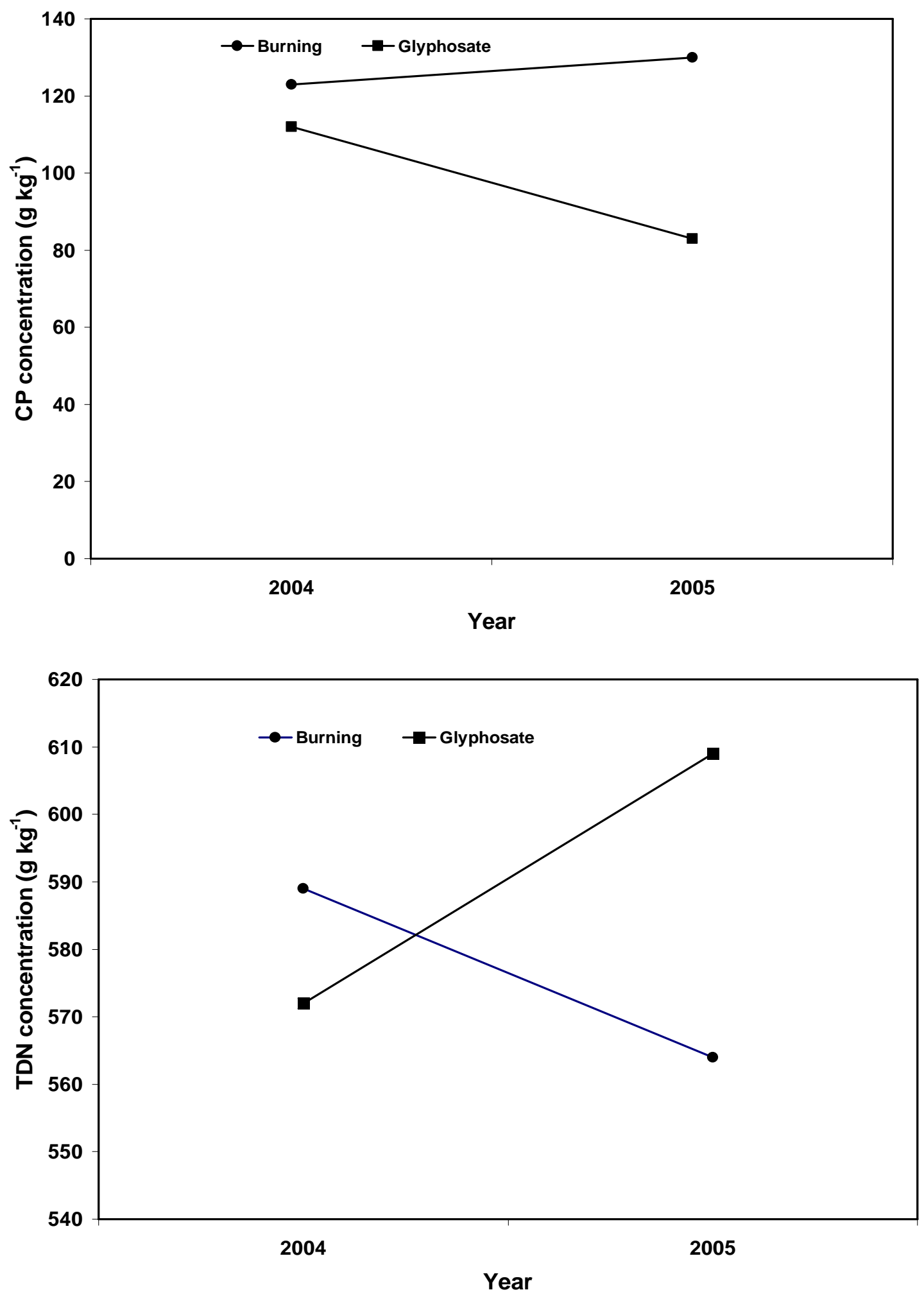

Figure 22. Effect of vegetation control and year on CP and TDN concentrations. Vegetation control by year interaction is significant at $P<0.05$. 
sudangrass while forage from those plots established after glyphosate application consisted mainly of sudangrass. During fall there was no significant effect of method of preplant vegetation control on nutritive value.

\section{N Levels}

There was no effect of $\mathrm{N}$ level on $\mathrm{CP}, \mathrm{ADF}, \mathrm{NDF}$ and TDN concentrations of summer crop. However, there was an overall effect of $\mathrm{N}$ across all species and all seasons. The $\mathrm{CP}, \mathrm{ADF}$ and NDF concentrations of unfertilized annual forage were not significantly different from those of forage fertilized with $50 \mathrm{~kg} \mathrm{~N} \mathrm{ha}^{-1}$. Forage receiving $100 \mathrm{~kg} \mathrm{~N} \mathrm{ha}^{-1}$ had significantly higher $\mathrm{CP}$ and lower ADF concentrations than both unfertilized and forage that received the low level of $\mathrm{N}$ (Table 6).

In fall, the $\mathrm{CP}, \mathrm{ADF}, \mathrm{NDF}$ and TDN concentrations of forages receiving 50 $\mathrm{kg} \mathrm{N} \mathrm{ha}^{-1}$ was not significantly different from those receiving $100 \mathrm{~kg} \mathrm{~N} \mathrm{ha}^{-1}$ (Table 7). However, unfertilized forages had lower CP and higher ADF concentrations than fertilized forages. The TDN and NDF concentrations of fertilized and unfertilized treatments were similar. 
Table 6. The effect of $\mathrm{N}$ level on $\mathrm{CP}, \mathrm{ADF}, \mathrm{NDF}$ and TDN concentrations of annual forages.

\begin{tabular}{lllll}
\hline N level & CP & ADF & NDF & TDN \\
\hline 0 & $152 a$ & $316 a$ & $519 a$ & $613 a$ \\
50 & $157 a b$ & $311 a b$ & $521 a$ & $618 b$ \\
100 & $168 b$ & $307 b$ & $524 a$ & $616 a b$ \\
\hline
\end{tabular}

Within $\mathrm{N}$ level, columns with the same letter are not significantly different at $\mathrm{P}<$ 0.05

Table 7. The effect of $\mathrm{N}$ level on $\mathrm{CP}, \mathrm{ADF}, \mathrm{NDF}$ and TDN concentrations of fall species.

\begin{tabular}{lllll}
\hline N level & CP & ADF & NDF & TDN \\
\hline 0 & $170 a$ & $276 a$ & $475 a$ & $638 a$ \\
50 & $187 b$ & $261 b$ & $466 a$ & $648 a$ \\
100 & $199 b$ & $257 b$ & $466 a$ & $648 a$ \\
\hline
\end{tabular}

Within $\mathrm{N}$ level, columns with the same letter are not significantly different at $\mathrm{P}<$ 0.05 . Nitrogen level by year interaction is significant for ADF at $P<0.05$. 


\section{Botanical Composition}

\section{Summer}

Pearl millet plots had significantly less legumes and dead material than either sudangrass or naturalized pasture plots (Table 8). Naturalized pasture plots had more legume and dead materials than sudangrass and pearl millet plots. Pearl millet plots had more weeds than sudangrass and naturalized pasture plots. Growth of pearl millet was slow compared to sudangrass, therefore, it did not effectively suppress weeds. The higher proportion of dead material in the naturalized pasture was because it was more mature and high temperatures accompanied by low precipitation accelerated senescence of these cool-season forages.

The proportion of grass in plots seeded after glyphosate application was not significantly different from that seeded after burning, but was higher than naturalized pasture. Naturalized pasture had the highest proportion of legume followed by plots seeded after burning while those seeded after glyphosate application had the least. Plots seeded after glyphosate application had a significantly higher proportion of weeds compared to plots seeded after burning and naturalized pasture. Naturalized pasture had similar dead material to plots after burning, but higher than plots established after glyphosate application. Plots established after glyphosate application consisted of a stand predominantly of sudangrass and pearl millet. However, pearl millet established after glyphosate application had more weeds than sudangrass established after glyphosate. The higher proportion of weeds in pearl millet established after 
Table 8. The effect of species,preplant vegetation control, and $\mathrm{N}$ level on botanical composition of summer crops.

\begin{tabular}{|c|c|c|c|c|}
\hline$\underline{\text { Variable }}$ & Grass & Legume & Weeds & Dead \\
\hline & & 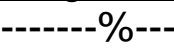 & & -'--' \\
\hline \multicolumn{5}{|l|}{ Species } \\
\hline Pearl millet & $67.7 \mathrm{~b}$ & $0.7 \mathrm{a}$ & $28.5 a$ & $3.1 \mathrm{c}$ \\
\hline Sudangrass & $83.0 \mathrm{a}$ & $2.6 \mathrm{~b}$ & $7.6 \mathrm{~b}$ & $6.8 b$ \\
\hline Naturalized Pasture & $61.3 b$ & $18.1 \mathrm{c}$ & $9.3 b$ & $11.3 \mathrm{a}$ \\
\hline \multicolumn{5}{|l|}{ Vegetation control } \\
\hline Burning & $75.7 a$ & $4.7 \mathrm{c}$ & $7.9 b$ & $11.7 \mathrm{a}$ \\
\hline Glyphosate & $79.0 \mathrm{a}$ & $0.6 b$ & $17.9 \mathrm{a}$ & $2.5 b$ \\
\hline Naturalized Pasture & $61.3 b$ & $18.1 \mathrm{a}$ & $9.3 b$ & $11.3 \mathrm{a}$ \\
\hline \multicolumn{5}{|l|}{$N$ level $\left(\mathrm{kg} \mathrm{ha}^{-1}\right)$} \\
\hline 0 & $65.7 \mathrm{~b}$ & $8.8 \mathrm{~b}$ & $17.0 \mathrm{a}$ & $8.4 a$ \\
\hline 50 & $77.0 \mathrm{a}$ & $4.55 a$ & $11.4 \mathrm{~b}$ & $7.0 \mathrm{a}$ \\
\hline 100 & $78.5 \mathrm{a}$ & $4.58 \mathrm{a}$ & $11.3 \mathrm{~b}$ & $5.6 \mathrm{a}$ \\
\hline
\end{tabular}


glyphosate was because glyphosate killed the natural vegetation, but the pearl millet was not dense, and lack of competition encouraged the growth of opportunistic weed species. Sudangrass canopy was dense at an early stage and suppressed weed growth. Forage mass from plots that received the high and low levels of $\mathrm{N}$ did not differ significantly in their proportions of grass, legume, and weeds. Unfertilized plots had a lower proportion of grass and higher proportion of legume and weeds than fertilized plots. The proportion of dead material was not affected by $\mathrm{N}$ level.

\section{Fall}

Naturalized pasture plots produced the highest proportion of legume followed by triticale plots and plots with the mixture of annual ryegrass and turnip were lowest (Table 9). Triticale plots and plots with the mixture had similar proportions of weeds and dead material. Naturalized pasture plots had a lower proportion of weeds and a higher proportion of dead material than either the mixture of annual ryegrass and turnip or triticale plots. Naturalized pasture plots had a higher proportion of dead material than plots with the fall annuals because forage in them was more mature.

Winter annuals established after both burning and glyphosate application had a higher proportion of grass and a lower proportion of dead material than naturalized pasture. The higher proportion of weeds in the annuals can be attributed to germination of weed seeds in the soil that appear to have been encouraged by both burning and glyphosate application. Burning breaks seed 
Table 9. The effect of species, preplant vegetation control, and $\mathrm{N}$ level on botanical composition of fall crops.

\begin{tabular}{|c|c|c|c|c|}
\hline Variable & Grass & Legume & Weeds & Dead \\
\hline & & -------\%--- & & \\
\hline \multicolumn{5}{|l|}{ Species } \\
\hline Mixture & $73.2 \mathrm{a}$ & $0.75 a$ & $13.8 \mathrm{a}$ & $12.2 \mathrm{a}$ \\
\hline Triticale & $79.0 \mathrm{~b}$ & $1.17 \mathrm{~b}$ & $9.5 \mathrm{a}$ & $10.3 a$ \\
\hline Naturalized Pasture & $69.2 \mathrm{a}$ & $3.68 c$ & $5.8 b$ & $21.3 b$ \\
\hline \multicolumn{5}{|l|}{ Vegetation control } \\
\hline Burning & $76.2 \mathrm{a}$ & $1.48 \mathrm{~b}$ & $12.95 b$ & $9.4 \mathrm{~b}$ \\
\hline Glyphosate & $75.9 a$ & $0.44 c$ & $10.4 \mathrm{a}$ & $13.2 \mathrm{~b}$ \\
\hline Naturalized Pasture & $69.2 \mathrm{~b}$ & $3.68 a$ & $5.8 a$ & $21.3 a$ \\
\hline \multicolumn{5}{|l|}{ N level $\left(\mathrm{kg} \mathrm{ha}^{-1}\right)$} \\
\hline 0 & $69.3 a$ & $2.0 \mathrm{a}$ & $13.1 \mathrm{a}$ & $15.6 a$ \\
\hline 50 & $76.0 \mathrm{~b}$ & $0.7 a$ & $10.9 a$ & $12.3 \mathrm{~b}$ \\
\hline 100 & $80.7 \mathrm{~b}$ & $0.9 \mathrm{a}$ & $9.1 \mathrm{a}$ & $9.3 b$ \\
\hline \multicolumn{5}{|l|}{ Year } \\
\hline 2004 & $66.0 \mathrm{a}$ & $1.9 a$ & $16.3 a$ & $15.8 \mathrm{a}$ \\
\hline 2005 & $84.6 \mathrm{~b}$ & $0.6 \mathrm{~b}$ & $5.8 \mathrm{~b}$ & $9.0 \mathrm{~b}$ \\
\hline
\end{tabular}

Within each variable, columns with the same letter are not significantly different at $\mathrm{P}<0.05$. 
dormancy and glyphosate application reduces competition for opportunistic weeds.

\section{Forage production systems}

A system in which sudangrass was established after glyphosate application in summer followed by either triticale or the mixture of annual ryegrass and turnip after glyphosate application in fall with $200 \mathrm{~kg} \mathrm{~N} \mathrm{ha}^{-1}$ produced the most forage DM (Table 10). In these systems, spring forage was not harvested because it was sprayed with glyphosate. Although these systems had $0 \mathrm{~kg} \mathrm{ha}^{-1}$ forage mass in spring, their high production was attributed to high forage accumulation of sudangrass.

Naturalized pasture produced good forage mass which was attributed to spring forage mass. This spring forage mass was the result of harvesting at the time of seeding the summer crops while the system where glyphosate was used to control vegetation was not harvested. Plots to be burnt were harvested on May 102004 and May 162005 and burning followed. Thus, all systems that included burning have spring yield.

Pearl millet seeded following burning failed to germinate. In this system, most of the summer vegetation was naturalized pasture. The fall species germinated and developed; and the mixture of annual ryegrass and turnip produced higher forage mass than triticale. 
Table 10. Forage accumulation from different production systems.

\begin{tabular}{|c|c|c|c|c|c|}
\hline \multirow{2}{*}{$\frac{\text { System* }}{\text { S-F-V-N }}$} & \multicolumn{4}{|c|}{ Season } & \multirow[b]{2}{*}{ Rank } \\
\hline & Spring & Summer & Fall & Total & \\
\hline & & 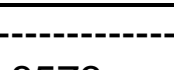 & $1 a^{-1} D N$ & --------- & \\
\hline $2-1-2-2$ & 0 & 8573 & 3160 & 11649 & 1 \\
\hline $2-2-2-2$ & 0 & 8573 & 2230 & 10886 & 2 \\
\hline $0-0-0-2$ & 4929 & 2854 & 2779 & 10562 & 3 \\
\hline 0-0-0-1 & 4929 & 2249 & 2813 & 10291 & 4 \\
\hline $1-1-1-2$ & 2163 & 3835 & 3351 & 9929 & 5 \\
\hline $2-1-1-2$ & 2163 & 4141 & 2865 & 9667 & 6 \\
\hline $0-0-0-0$ & 4929 & 2281 & 2244 & 9454 & 7 \\
\hline $2-2-1-2$ & 2163 & 4141 & 2346 & 9357 & 8 \\
\hline $1-2-1-2$ & 2163 & 3835 & 2645 & 9270 & 9 \\
\hline $1-1-2-2$ & 0 & 5138 & 3816 & 8968 & 10 \\
\hline 2-2-1-1 & 2163 & 3606 & 2043 & 8704 & 11 \\
\hline 1-1-1-1 & 2163 & 3403 & 2471 & 8570 & 12 \\
\hline $1-2-1-1$ & 2163 & 3403 & 2471 & 8570 & 13 \\
\hline 2-1-1-1 & 2163 & 3606 & 2260 & 8343 & 14 \\
\hline $2-1-2-1$ & 0 & 6293 & 2290 & 8342 & 15 \\
\hline $2-2-2-1$ & 0 & 6293 & 1730 & 8265 & 16 \\
\hline $2-1-2-0$ & 0 & 5982 & 1981 & 7971 & 17 \\
\hline $1-2-2-2$ & 0 & 5158 & 2320 & 7485 & 18 \\
\hline $1-1-1-0$ & 2163 & 2836 & 1633 & 7286 & 19 \\
\hline $2-2-1-0$ & 2163 & 3069 & 1286 & 7225 & 20 \\
\hline $2-2-2-0$ & 0 & 5982 & 1217 & 7192 & 21 \\
\hline $2-1-1-0$ & 2163 & 3069 & 1435 & 7167 & 22 \\
\hline $1-1-2-1$ & 0 & 3675 & 3384 & 6959 & 23 \\
\hline $1-2-1-0$ & 2163 & 2836 & 1280 & 6832 & 24 \\
\hline $1-2-2-1$ & 0 & 3675 & 2203 & 5977 & 25 \\
\hline $1-1-2-0$ & 0 & 2982 & 2111 & 5100 & 26 \\
\hline $1-2-2-0$ & 0 & 2982 & 1536 & 4512 & 27 \\
\hline
\end{tabular}

Data are averages of 2 years (2004 and 2005).

*S-F-V-N, where S refers to summer species; $1=$ Pearl millet, 2= sudangrass and $0=$ naturalized pasture. $F$ refers to fall species; $1=$ A mixture of annual ryegrass and turnip, $2=$ triticale and $0=$ naturalized pasture. $V$ refers to preplant vegetation control; $0=$ control, $1=$ burning and $2=$ glyphosate. $\mathrm{N}$ refers to $\mathrm{N}$ level; $0=0 \mathrm{~kg} \mathrm{ha}^{-1}$ $\mathrm{yr}^{-1}, 1=100 \mathrm{~kg} \mathrm{ha}^{-1} \mathrm{yr}^{-1}$ and $2=200 \mathrm{~kg} \mathrm{ha}^{-1} \mathrm{yr}^{-1}$. 


\section{Economic analysis of different forage production systems}

The calculations of economic returns for all combinations of treatments are given in the Appendix Tables $2 a$ to $3 y$. Net returns per hectare over variable costs are summarized in Table 11. Revenues were calculated based on the same price per ton of DM of hay equivalent. Variable costs include seed, fertilizer, propane gas, herbicide, and labor. Machinery cost and labor were included in the cost associated with application of either glyphosate or burning. Fixed costs were excluded because they are common to all systems. Net returns are total crop value minus variable costs.

The data used in the calculation of net returns were the averages of 2004 and 2005. In addition, spring residual yield of the 2005 fall crop was included (Table 11). The system producing the highest net return $\mathrm{ha}^{-1}$ was naturalized pasture with $100 \mathrm{~kg} \mathrm{ha}^{-1} \mathrm{y}^{-1}$ of $\mathrm{N}$ (Table 11). The system involving annuals that followed natural pasture was sudangrass after glyphosate followed by triticale after glyphosate with $200 \mathrm{~kg} \mathrm{ha}^{-1} \mathrm{y}^{-1}$ of $\mathrm{N}$. The high net return from naturalized pasture can be attributed to low input cost with no use of seeds, herbicides and establishment costs. The good economic return from a system where sudangrass was grown in summer followed by triticale in fall was attributed to high forage accumulation in summer that increased income. Although systems involving naturalized pasture had higher net annual returns than those involving annuals, the latter can provide higher quantity and quality of forage in summer and fall when demands from weaned calves or stocker cattle may be higher. 
However, introducing annual forages in summer and fall require considerable establishment costs.

In summer, the DM production of sudangrass was higher than that of pearl millet but the higher seed rate and cost lowered its economic ranking. In fall the mixture of annual ryegrass and turnip obtained low ranking because of high cost of turnip seed.

The systems where glyphosate was used as a method of vegetation control before establishing annual forages had higher net returns than those where burning was used. The higher net return of the system using glyphosate was attributed to low machinery and labor cost. The boom sprayer covers six times the width covered with the flame cultivator, thus saving labor costs. 
Table 11. Net return per hectare over variable costs for different production systems.

\begin{tabular}{|c|c|c|c|c|c|c|}
\hline \multirow{2}{*}{$\begin{array}{l}\text { System } \\
\text { S-F-V-N }\end{array}$} & \multicolumn{5}{|c|}{ Net Return ${ }^{2}$} & \multirow[b]{2}{*}{ Rank } \\
\hline & Spring & Summer & Fall 1 & Fall 2 & Total & \\
\hline $0-0-0-1$ & 296 & 98 & 114 & 227 & 734 & 1 \\
\hline $0-0-0-0$ & 296 & 137 & 135 & 111 & 678 & 2 \\
\hline $0-0-0-2$ & 296 & 74 & 70 & 211 & 650 & 3 \\
\hline $2-2-2-2$ & 0 & 159 & -91 & 337 & 405 & 4 \\
\hline $1-2-1-1$ & 130 & 8 & -31 & 232 & 339 & 5 \\
\hline $1-2-2-2$ & 0 & 52 & -85 & 356 & 322 & 6 \\
\hline $2-2-2-0$ & 0 & 101 & -64 & 278 & 313 & 7 \\
\hline $1-2-1-2$ & 130 & -31 & -46 & 259 & 312 & 8 \\
\hline $1-2-2-1$ & 0 & 5 & -32 & 275 & 247 & 9 \\
\hline $2-2-2-1$ & 0 & 64 & -78 & 300 & 222 & 10 \\
\hline $1-2-2-0$ & 0 & 18 & -30 & 232 & 220 & 11 \\
\hline $1-2-1-0$ & 130 & 7 & -53 & 129 & 213 & 12 \\
\hline $2-2-1-1$ & 130 & -100 & -63 & 221 & 188 & 13 \\
\hline $2-2-1-2$ & 130 & -110 & -87 & 245 & 178 & 14 \\
\hline $2-2-1-0$ & 130 & -77 & -66 & 150 & 137 & 15 \\
\hline $1-1-1-0$ & 130 & 7 & -145 & 101(104) & 93 & 16 \\
\hline $2-1-2-2$ & 0 & 159 & -148 & $63(189)$ & 74 & 17 \\
\hline $1-1-1-2$ & 130 & -31 & -139 & $107(138)$ & 67 & 18 \\
\hline $1-1-1-1$ & 130 & 8 & -128 & $56(170)$ & 66 & 19 \\
\hline $1-1-2-1$ & 0 & 5 & -35 & $48(228)$ & 53 & 20 \\
\hline $2-1-2-0$ & 0 & 101 & -134 & $71(163)$ & 38 & 21 \\
\hline $2-1-1-0$ & 130 & -77 & -135 & $97(67)$ & 15 & 22 \\
\hline $1-1-2-2$ & 0 & 52 & -90 & $49(251)$ & 11 & 23 \\
\hline $1-1-2-0$ & 0 & 18 & -114 & $72(213)$ & -24 & 24 \\
\hline $2-1-2-1$ & 0 & 64 & -158 & 66(193) & -28 & 25 \\
\hline 2-1-1-1 & 130 & -100 & -162 & $102(118)$ & -30 & 26 \\
\hline $2-1-1-2$ & 130 & -110 & -168 & $117(119)$ & -31 & 27 \\
\hline
\end{tabular}

${ }^{1} \mathrm{~S}-\mathrm{F}-\mathrm{V}-\mathrm{N}$, where $\mathrm{S}$ refers to summer species; $1=$ pearl millet, $2=$ sudangrass and $0=$ naturalized pasture. $F$ refers to fall species; $1=$ mixture of annual ryegrass and turnip, $2=$ triticale and $0=$ naturalized pasture. $V$ refers to vegetation control; $0=$ control, $1=$ burning and $2=$ glyphosate. $\mathrm{N}$ refers to $\mathrm{N}$ level; $0=0 \mathrm{~kg} \mathrm{ha}^{-1} \mathrm{yr}^{-1}, 1=$ $100 \mathrm{~kg} \mathrm{ha}^{-1} \mathrm{yr}^{-1}$ and $2=200 \mathrm{~kg} \mathrm{ha}^{-1} \mathrm{yr}^{-1}$

${ }^{2}$ Net returns $=$ total crop value - total variable costs

Spring harvest $=$ pre-plant harvest

Fall $1=$ November $15^{\text {th }}$ harvest and Fall 2 refers to May $4^{\text {th }}$ harvest.

Fall 2= May $4^{\text {th }} 2006$ harvest, numbers in parenthesis refer to revenue from turnip that was not factored in here but was factored in fall 1 net return because turnip harvest involve a whole plant. 


\section{CHAPTER FIVE: CONCLUSIONS}

This two-year study was carried out at the Reedsville Experimental Farm, Reedsville, WV. Weather conditions in 2004 were wet and cool whereas in 2005 they were warmer and drier. Sudangrass grown in summer produced the most forage mass but was of lower quality than naturalized pasture forage. Pearl millet was more susceptible to competition than sudangrass. Pearl millet established after burning failed to germinate and develop due to competition from regrowth of the naturalized vegetation. Rapid growth of both sudangrass and pearl millet occurred between 30 and 50 days after seeding. Nitrogen application increased forage mass for all forage species grown in summer and fall. However, high economic returns were obtained only from sudangrass grown in summer. In addition, nitrogen application hastened physiological maturity of both sudangrass and pearl millet. Forage accumulation from annuals established after glyphosate application was higher than that from those established after burning. Use of glyphosate as a preplant method of vegetation control was more profitable than the use of burning.

Naturalized pasture and the mixture of annual ryegrass and turnip produced similar forage mass to each other but higher than triticale in fall. However, the cost of seed and establishment cost for these fall annuals was higher than naturalized pasture. Some establishment costs were recovered when fall established annuals were harvested the following spring.

Naturalized pasture that received $100 \mathrm{~kg} \mathrm{~N} \mathrm{ha}^{-1}$ split into two equal portions and applied in summer and fall was ranked the highest in economic 
returns. For annual forages, a system where sudangrass was grown in summer and triticale in fall produced the highest economic returns when $\mathrm{N}$ was applied at the rate of $200 \mathrm{~kg} \mathrm{ha}^{-1} \mathrm{yr}^{-1}$ and glyphosate was used as a method of preplant vegetation control. In terms of forage accumulation a system with sudangrass after glyphosate in summer and a mixture of annual ryegrass after glyphosate in fall produced the highest DM but, high cost of turnip seed lowered the economic ranking of the annual ryegrass and turnip mixture. In summer, sudangrass produced higher DM production than pearl millet but the high cost of seed and high seed rate lowered its net return.

The results of this study suggest that sudangrass can be used to supplement naturalized pasture in summer while triticale or a mixture of annual ryegrass and turnip can be used in fall for both high quality and quantity supplemental feeds. Furthermore, fall annuals can be managed for residual harvest in spring increasing productivity and economic returns. Impacts on risk need to be investigated in further research. 


\section{REFERENCES}

Allen, V. G., J. P. Fontenot, D. R. Notter, and R. C. Hammes, Jr. 1992. Forage systems for beef production from conception to slaughter: 1. Cowcalf production. J. Anim. Sci. 70: 576-587.

Allen, V. G., and M. Collins. 2003. Grazing management systems. In R. F. Barnes, C. J. Nelson, M. Collins, and K. J. Moore (eds.). Forages: An Introduction to Grassland Agriculture, $6^{\text {th }}$ ed., Vol. 1, 473-501. lowa State Press, Ames, lowa.

Arthington, J. D., and R. S. Kalmbacher. 2003. Effect of early weaning on the performance of three-year-old first calf beef heifers and calves reared in the Subtropics. J. Anim. Sci. 81:1136.

Baker, M. J., E. C. Prigge, and W. B Bryan. 1988. Herbage production from hay fields grazed by cattle in fall and spring. J. Prod. Agric. 1:275-279.

Balasko, J. A., G. W. Evers, and R. W. Duell. 1995. Bluegrass, ryegrass, and bentgrass. 1995. In R. F. Barnes, D. A. Miller, and C. J. Nelson (eds.). Forages: An Introduction to Grassland Agriculture, $5^{\text {th }}$ ed., Vol. 1, 357-371. lowa State University Press, Ames, lowa.

Balasko, J. A., and J. Nelson. 2003. Grasses for Northern areas. In R. F. Barnes, C. J. Nelson, M. Collins, and K. J. Moore (eds.). Forages: An Introduction to Grassland Agriculture, $6^{\text {th }}$ ed., Vol. 1, 125-148. Iowa State Press, Ames, lowa.

Balasko, J. A. 1977. Effects of N, P, and K fertilization on yield and quality of tall fescue forage in winter. Agron. J. 69: 425-428.

Ball, D. M., C. S. Hoveland, and G. D. Lacefield. 1996. Southern Forages. Second edition. Williams Printing Company, Atlanta, Georgia.

Barnes, R. F., and C. J. Nelson. 2003. Forages and grasslands in the changing world. In R. F. Barnes, C. J. Nelson, M. Collins, and K. J. Moore (eds.). Forages: An Introduction to Grassland Agriculture, $6^{\text {th }}$ ed., Vol. 1, 3-23. lowa State Press, Ames, lowa:

Brar, G. S., and B. A. Stewart. 1995. Germination under controlled temperature and field emergence of 13 sorghum cultivars. Crop Sci. 34: 1336-1340. 
Brock, J. L., and R. J. M. Hay. 1993. An ecological approach to forage management. p. 837-842. In Proceedings of the XVII International Grassland Congress. Palmerston North, NZ.

Broyles, K. R., and H. A. Fribourg. 1959. Nitrogen fertilization and cutting management of sudangrass and millets. Agron. J. 51: 277-279.

Bruckner, P. L., and P. L. Raymer. 1990. Factors influencing species and cultivar choice of small grains for winter forage. J. Prod. Agric. 3: 349355.

Bryan, W. B. 1985. Effects of sod-seeding legume on hill land pasture productivity and composition. Agron. J. 77: 901-905.

Bryan, W. B., and T. A. Mills. 1988. Seasonality of pasture growth in West Virginia. Proceedings of the $12^{\text {th }}$ General Meeting of the European Grassland Federation, Dublin, Ireland. July 4-7, p. 382-386.

Bryan, W. B., E. C. Prigge, and R. O. Burton. 1986. Beef cow/calf production on conventional and innovative systems. In Proc. Ame. Forage and Grassl. Conf., Athens, Georgia. April 15-17, p.192-195.

Bryan, W. B., E. C. Prigge, M. Lasat, T. Pasha, D. J. Flaherty, and J. Lozier. 2000. Productivity of Kentucky bluegrass pasture grazed at three heights and two intensities. Agron. J. 92:30-35.

Burger, A. W., and C. N. Hittle. 1967. Yield, protein, nitrate, and prussic acid content of sudangrass, sudangrass hybrids, and pearl millets harvested at two cutting frequencies and two stubble heights. Agron. J. 59:259-262.

Butler, T. W., J. F. Stritzke, L. A. Redmon, and C. L. Goad. 2002. Methods of establishing annual ryegrass and clover into broomsedge-infested pasture. Agron. J. 94:1344-1349.

Camara, K. M., W. A. Payne, and P. E. Rasmussen. 2003. Long-term effects of tillage, nitrogen, and rainfall on winter wheat yields in the Pacific Northwest. Agron. J. 95: 828-835.

Chessmore, R. A. 1979. Profitable pasture management. The Interstate Printers and Publishers, Inc., Danville, Illinois.

Choat, W. T., C. R. Krebbiel, G. C. Duff, R. E. Kirksey, L. M. Lauriault, J. D. Rivera, B. M. Capitan, D. A. Walker, G. B. Donart, and C. L. Goad. 2003. Influence of grazing dormant native range or winter wheat pasture on subsequent finishing cattle performance, carcass characteristics, and ruminal metabolism. J. Anim. Sci. 81: 3191-3201. 
Clapp, J. G., Jr., and D. S. Chamblee. 1970. Influence of different defoliation systems on the regrowth of pearl millet, hybrid sudangrass, and two sorghum-sudangrass hybrids from terminal, axillary, and basal buds. Crop Sci. 10: 345-349.

Clark, N. A., R. W. Hemken, and J. H. Vandersall. 1965. A comparison of pearl millet, sudangrass, and sorghum-sudangrass hybrid as pasture for lactating dairy cows. Agron. J. 57: 266-269.

Coffey, K. P., W. K. Coblentz, T. G. Montgomery, J. D. Shockey, K. J. Bryant, P. B. Francis, C. F. Rosenkrans, Jr., and S. A. Gunter. 2002. Growth performance of stocker calves backgrounded on sod-seeded winter annuals or hay and grain. J. Anim. Sci. 80: 926-932.

Collins, M., and J. A. Balasko. 1981a. Effects of $\mathrm{N}$ fertilization and cutting schedules on stockpiled tall fescue: I. Forage yield. Agron. J. 73: 803807.

Collins, M., and J. A. Balasko. 1981b. Effects of $\mathrm{N}$ fertilization and cutting schedules on stockpiled tall fescue: II. Forage quality. Agron. J. 73: 821--826.

Collins, M., and J. O. Fritz. 2003. Forage quality. In R. F. Barnes, C. J. Nelson, M. Collins, and K. J. Moore (eds.). Forages: An Introduction to Grassland Agriculture, $6^{\text {th }}$ ed., Vol. 1, 363-390. Iowa State Press, Ames, lowa.

Collins, M., and V. N. Owens. 2003. Preservation of forage as hay and silage. In R. F. Barnes, C. J. Nelson, M. Collins, and K. J. Moore (eds.). Forages: An Introduction to Grassland Agriculture, $6^{\text {th }}$ ed., Vol. 1, 443471. Iowa State Press, Ames, Iowa.

Colyer, D., F. L. Alt, J. A. Balasko, P. R. Henderlong, G. A. Jung, and V. Thang. 1977. Economic optima and price sensitivity of $\mathrm{N}$ fertilization for six perennial grasses. Agron. J. 69: 514-517.

Creamer, N. G., and K. R. Baldwin. 2000. An evaluation of summer cover crops for use in vegetable production systems in North Carolina. Hortsci. 35: $600-603$.

Cuomo, G. J., D. D. Redfearn, J. F. Beatty, R. A. Anders, F. B. Martin, and D. C. Blouin. 1999. Management of warm-season annual grass residue on annual ryegrass establishment and production. Agron. J. 91: 666671. 
D'Souza, G. E., E. W. Maxwell, W. B. Bryan, and E. C. Prigge. 1990. Economic impacts of extended grazing systems. Ame. J. Alt. Agric. 5: 120-125.

D'Souza, G. E., R. F. Romero, and D. K. Smith. 1988. The investment potential of warm-season grasses for hill-land beef producers. Northeastern J. Agric. Res. Econ. 17: 56-63.

Evers, G. W., G. R. Smith, and C. S. Hoveland. 1997. Ecology and production of annual ryegrass. In , F. M. Rouquette, Jr., and L. R. Nelson (eds.). Proceedings of a Symposium Sponsored by Divisions C-3, C-4, and C-6 of the Crop Science Society of America in St. Louis, Missouri, 29 Oct.- 3 Nov. 1995.

Evans, J. R. 2003. An economic analysis of pasture-raised beef systems in Appalachia. M.S. Thesis, Agricultural and Resource Economics, West Virginia University, Morgantown, WV.

Finney, D. M. 2005. Evaluation of sorghum sudangrass as a summer cover crop and marketable hay crop for organic, no-till production of fall cabbage. M.S. Thesis, North Carolina State University, Raleigh, NC.

Flaherty, D. J. 1992. Buffer grazing in a 12 month cow-calf production system. M.S. Thesis, West Virginia University, Morgantown, WV.

Fontaneli, R. S., L. E. Sollenberger, and C. R. Staples. 2001. Yield distribution, and nutritive value of intensively managed warm-season annual grasses. Agron. J. 93: 1257-1262.

Forwood, J. R., A. M. da Silva, and J. A. Paterson. 1988. Grazing behavior of steers on season-long vs complementary grazing systems. In Proc. 1988 Ame. Forage and Grassl. Conf., Baton Rouge, LA. April 11-14, p. 102-104.

Frank, A. B. 1996. Evaluating grass development for grazing management. Rangelands 18: 106-109.

Graves, R. E., and P. J. Vanderstappen. 1993. Environemental problems with silage effluent. In Silage Production from Seed to Animal, Proceedings from National Silage production Conference, Syracuse, NY. February 2325.

Griffith, S. M., and T. G. Chastain. 1997. Physiology and growth of ryegrass. In F. M. Rouquette, Jr., and L. R. Nelson (eds.). Proceedings of a Symposium Sponsored by Divisions C-3, C-4, and C- 6 of the Crop Science Society of America in St. Louis, Missouri, 29 Oct.- 3 Nov. 1995. 
Groya, F. L., and C. C. Sheaffer. 1981. Establishemnt of sod-seeded alfalfa at various levels of soil moisture and grass competition. Agron. J. 73: 560-565.

Guillard, K., D. W. Allinson, and R. L. Hough. 1988. Performance of sheep grazing fall-grown tyfon. Appli. Agric. Res. 3: 86-93.

Gunter, S. A., K. A. Cassida, P. A. Beck, and J. M. Phillips. 2002. Winter annual pasture as a supplement for beef cows. J. Anim. Sci. 80: 11571165.

Haby, V. A., and D. L. Robinson. 1997. Soil fertility and liming practices for production of annual ryegrass. In F. M. Rouquette, Jr., and L. R. Nelson (eds.). Proceedings of a Symposium Sponsored by Divisions C-3, C-4, and C-6 of the Crop Science Society of America in St. Louis, Missouri, 29 Oct.- 3 Nov. 1995.

Hall, M. 2004. Managing for quality forage. In K. Cassida (ed.). Proc. Ame. Forages and Grassl. Counc. June 12-16, Roanoke, Virginia.

Harms, C. L., and B. B. Tucker. 1973. Influence of nitrogen fertilization and other factors on yield, prussic acid, nitrate, and total nitrogen concentrations of sudangrass cultivars. Agron. J. 65: 21-26.

Hart, R. H., and G. W. Burton. 1965. Effect of row spacing, seeding rate, and nitrogen fertilization on forage yield and quality of Gahi-1 pearl millet. Agron. J. 57: 376-378.

Hart, R. H., H. J. Retzer, R. F. Dudley, and G. E. Carlson. 1971. Seeding sorghum $x$ sudangrass hybrids into tall fescue sod. Agron. J. 63: 478480.

Haun, J. R. 1973. Visual quantification of wheat development. Agron. J. 65: 116-119.

Heringer, I., E. L. Moojen. 2002. Productive potential, structural changes and quality of pearl millet under different nitrogen levels. Revista Brasileira de Zootechia 31: 875-882.

Holt, E. C., and G. D. Alston. 1968. Response of sudangrass hybrids to cutting practices. Agron. J. 60: 303-306.

Humpreys, L. R. 1978. Tropical Pastures and Fodder Crops. Intermediate Tropical Agriculture Series. Longman Group Ltd. 
Hypes, S. L. 1993. Use of nitrogen fertilizer on tall fescue to extend the grazing season. M.S. Thesis, West Virginia University, Morgantown.

Janovick, N. A., J. R. Russell, D. R. Strohbehn., and D. G. Morrical. 2004. Productivity and hay requirements of beef cattle in a Midwestern yearround grazing system. J. Anim. Sci. 82: 2503-2515.

Jung, G. A., and J. A. Shaffer. 1995. Planting and harvest date effects on productivity and root/shoot quotient of four brassica cultivars. Agron. J. 87: 1004-1010.

Jung, G. A., and J. A. Shaffer. 1993. Planting and seeding date effects on morphological development and yield of turnip. Crop Sci. 33: 1329-1334.

Jung, G. A., and R. L. Reid. 1966. Sudangrass: Studies on its yield, management, chemical composition and nutritive value. Bull. 524T. West Virginia University Agricultural Experiment Station.

Jung, G. A., B. Lilly, S. C. Shih, and R. L. Reid. 1964. Studies with sudangrass. 1. Effect of growth stages and levels of nitrogen fertilizer upon yield of dry matter; Estimated digestibility of energy, dry matter and protein; Amino acid composition; and prussic acid potential. Agron. J. 56: 533-537.

Kallenbach, R. L., G. T. Bishop-Hurley, M. D. Massie, M. S. Kerley, and C. A. Roberts. 2003. Stockpiled annual ryegrass for winter forage in lower Midwestern USA. Crop Sci. 43: 1414-1420.

Kalu, B. A., and G. W. Fick. 1981. Quantifying morphological development of alfalfa for studies of herbage quality. Crop Sci. 21: 267-271.

Laberge, G., P. Seguin, P. R. Peterson, C. C. Sheaffer, N. J. Ehlke, G. J. Cuomo, and R. D. Mathison. 2005. Establishment of kura clover notilled into grass pastures with herbicide sod suppression and nitrogen fertilization. Agron. J. 97:250-256

Lopez-Dominguez, U., R. K. Maiti, P. W. Ebeling, L. R. G. Ramirez, and J. Verde Star. 2001. Agrobiological factors influencing the productivity and forage quality of some pearl millet (Pennisetum glaucum (L.) R.Br. Emend stuntz) cultivars in Marin, Nuevo Leon. Research on Crops 2: 263-277.

Lozier, J., E. Rayburn, and J. Shaw. 2004. Growing and selling pasturefinished beef: Results of a nationwide survey. J. Sust. Agric. 25: 93-112

Maloney, T. S., E. S. Oplinger, and K. A. Albrecht. 1999. Small grains for fall and spring forage. J. Prod. Agric. 12: 488-494. 
Marschner, H. 1995. Mineral nutrition of higher plants. Second edition, Academic Press, San Diego, CA.

McLaughlin, M. R., T. E. Fairbrother, and D. E. Rowe. 2004. Forage yield and nutrient uptake of warm-season annual grasses in a swine effluent spray field. Agron. J. 96: 1516-1522.

Medal, J. C. 1986. Yield and quality of winter annual forages. M.S. Thesis. West Virginia University, Morgantown.

Mehlich, A. 1953. Determination of $\mathrm{P}, \mathrm{Ca}, \mathrm{Mg}, \mathrm{Na}$, and $\mathrm{NH}_{4}$. North Carolina Soil Test Division (Mimeo 1953).

Miller, D. A., and J. F Stritzke. 1995. Forage establishment and weed management. In R. F. Barnes, D. A. Miller, and C. J. Nelson. (eds.). Forages: An Introduction to Grassland Agriculture, $5^{\text {th }}$ ed., Vol. 1, 89-104. lowa State University Press, Ames, lowa.

Minson, D. J. 1990. Forage in Ruminant Nutrition. Academic Press, San Diego, California.

Moore, K. C., and C. J. Nelson. 1995. Economics of forage production and utilization. In Barnes et al. (eds.). Forages: An Introduction to Grassland Agriculture, $5^{\text {th }}$ ed., Vol. 1, 189-202. Ames: lowa State Univ. Press.

Moore, K. J., L. E. Moser, K. P. Vogel, S. S. Waller, B. E. Johnson, and J. F. Pedersen. 1991. Describing and quantifying growth stages of perennial forage grasses. Agron. J. 81: 1073-1077.

Moore, K. J., T. A. White, R. L. Hintz, P. K. Patrick, and E. C. Brummer. 2004. Sequential grazing of cool- and warm-season pastures. Agron. J. 96: 1103-1111.

Monks, C. D., T. Basden, J. L. Hatton, M. L. McFarland, S. M. Poland, and E. Rayburn. 1997. Cover crop response to late-season planting and nitrogen application. J. Prod. Agric. 10: 289-293.

Pearson, C. J., and R. L. Ison. 1997. Agronomy of Grassland Systems. $2^{\text {nd }}$ Edition, Cambridge University Press.

PennState Agronomy Guide 2005-2006. http://agguide.agronomy.psu.edu/cm/sec8/sec87a.cfm. Accessed on $\underline{3 / 28 / 06}$. 
Piaggio, L., and E. R. Prates. 1997. Dry matter intake and liveweight gain related to sward characteristics and quality. In Proceedings of the XVIII International Grassland Congress. Winnipeg, Manitoba Saskatoon, Saskatchewan, Canada, June, 8 - 19.

Pitts, R. E. 1990. Silage and hay preservation. Natural Resource, Agriculture, and Engineering Services, Cooperative Extension, Ithaca, NY.

Prigge, E. C., W. B. Bryan, and E. S. Goldman-Innis. 1999. Early- and lateseason grazing of orchardgrass and fescue hayfields overseeded with red clover. Agron. J. 91: 690-696.

Purser, D. B. 1981. Nutritional value of Mediterranean pastures. In F. H. W. Morley (ed.). Grazing Animals. Elsevier Scientific publishing Company. NY.

Rayburn, E. B. 1977. Quality and yield of tall fescue (Festuca arundinacea Schreb.) as affected by season, legume combination and fertilization. Ph.D. Thesis. Virginia Polytechnic Institute and State University. Blacksburg, Virginia.

Rayburn, E. B., and S. B. Rayburn. 1998. A standardized plate meter for estimating mass in on-farm research trials. Agron. J. 90: 238-241.

Redfearn, D. D., B. C. Venuto, W. D. Pitman, M. W. Alison, and J. D. Ward. 2002. Cultivar and environmental effects on annual ryegrass forage yield, yield distribution, and nutritive value. Crop Sci. 42: 2049-2054.

Rees, R. G., and G. J. Platz. 1998. The occurrence and control of yellow spot of wheat in north-eastern Australia. Australian J. Exp. Agric. and Anim. Husb. 19: 369-372.

Reid, R. L., J. R. Puoli, G. A. Jung, J. M. Cox-Ganser, and A. McCoy. 1994. Evaluation of brassicas in grazing systems for sheep: I. Quality of forage and animal performance. J. Anim. Sci. 72:1823-1831.

Rhykerd, C. L., C. F. Gross, and E. F. Sullivan. 1960. Sorghum grows best at warm temperatures. Crops and Soil 12: 24.

Robinson, L. R., and H. D. Wittmus. 1973. Evaluation of herbicides for use in zero and minimized tilled corn and sorghum. Agron. J. 65: 283-286.

Rozas, H. R. S., H. E. Echeverría, and P. A. Barbieri. 2004. Nitrogen balance as affected by application time and nitrogen fertilizer rate in irrigated no-tillage maize. Agron. J. 96: 1622-1631. 
Sanderson, M. A., R. R. Schnabel, W. S. Curran, W. L. Stout, D. Genito, and B. F. Tracy. 2004. Switchgrass and big bluestem hay, biomass, and seed yield response to fire and glyphosate treatment. Agron. J. 96: 16881692.

SAS. 2001. SAS Institute Inc., Carry, NC, USA.

Schwarte, A. J., L. R. Gibson, D. L. Karlen, M. Liebman, and J. L. Jannink. 2005. Planting date effects on winter triticale dry matter and nitrogen accumulation. Agron. J. 97: 1333-1341.

Smith, D. H., and M. Collins. 2003. Forbs. In R. F. Barnes, C. J. Nelson, M. Collins, and K. J. Moore (eds.). Forages: An Introduction to Grassland Agriculture, $6^{\text {th }}$ ed., Vol. 1, 215-236. lowa State Press, Ames, lowa

Snapp, S. S., S. M. Swinton, R. Labarta, D. Mutch, J. R. Black, R. Leep, J. Nyiraneza, and K. O'Neil. 2005. Evaluating cover crops for benefits, costs and performance within cropping system niches. Agron. J. 97: 322-332.

Selk, G. E., D. G. Wagner, G. L. Strickland, S. E. Hawkins, and S. Janloo. 1993. Nitrogen fertilizer rate on nitrate content of hybrid sudangrass hays. Animal Science Research Report 140, Oklahoma Agricultural Experiment Station, Oklahoma.

Shoemaker, H. H., E. O. McLean, and P. Pratt. 1961. Buffer methods of determining lime requirements of soils with appreciable amounts of extractable aluminum. Soil Sci. Soc. Ame. Proc. 25: 274-277.

Stafford, C. C., J. H. Fike, S. R. Smith, P. R. Peterson, and D. E. Starner. 2004. Yield response of five cool season grasses to various nitrogen management. In K. Cassida. (ed.). Proc. Ame. Forage and Grassl. Counc. June 12-16 Roanoke, Virginia.

Sumner, D. C., W. E. Martin, and H. S. Etchegaray. 1965. Dry matter and protein yields and nitrate content of piper sudangrass (Sorghum sudanense (piper) Stapt.) in response to nitrogen fertilization. Agron. J. 57: 351-354.

Undersander, D. 2004. What is forage quality and is it worth making? In K. Cassida (ed.). Proc. Ame. Forage and Grassl. Counc. June 12-16. Roanoke, Virginia.

Van Soest, J., B. Robertson, and B. A Lewis. 1991. Symposium: Carbohydrate methodology, metabolism, and nutritional implications in dairy cattle. J. Dairy Sci. 74: 3583-3597. 
Vickery, P. J. 1981. Pasture growth under grazing. In F. H. W. Morley (ed.). Grazing Animals. Elsevier Scientific Publishing Company. NY.

Voet, D., and J. Voet. 1995. Biochemistry, Second Edition, John Wiley and Sons, Inc.

Weed Control Manual. 2000. Volume 32, 2000. Ag Consultant and Fieldman. Willoughby, Ohio.

Weinert, T. L., M. R. Moneymaker, G. S. Santo, and R. G. Stevens. 2002. Nitrogen recycling by non leguminous winter crops to reduce leaching. Agron. J. 94: 365-372.

West Virginia Agricultural Statistics. 1997. West Virginia Department of Agriculture, Charleston.

White, E. H. 1983. No-till forage establishment. Proceedings of the $39^{\text {th }}$ Southern Pasture and Forage Crop Improvement Conference. May 23-26. Oklahoma City, Oklahoma.

Whitehead, D. C. 1995. Grassland Nitrogen. CAB International, Wallingford, UK.

Wiatrak, P. J., D. L. Wright, and J. J. Marois 2004. Tillage and residual nitrogen impact on wheat forage. Agron. J. 96: 1761-1764.

Wiedenhoeft, M. H. 1993. Management and environment effects on dry matter yield of three brassica species. Agron. J. 85: 549-553.

Wiedenhoeft, M. H., and B. A. Barton. 1994. Management and environment effects on brassica forage quality. Agron. J. 86: 227-232.

Williams, M. J., E. Valencia, and L. E. Sollenberger. 2002. No-till establishment of rhizoma peanut. Agron. J. 94:1350-1354.

Windham, W. R., D. R. Mertens, and F. E. Barton II. 1989. Protocol for NIRS calibration: Sample selection and equation development and validation. p. 96-103. In G. C. Marten, J. S. Shenk, F. E. Barton II . (eds.). Near infrared reflectance spectroscopy (NIRS): Analysis of forage quality. USDA Agric. Handb. 643. US Gov. Print. Office, Washington, DC.

Worker, G. F., Jr. 1973. Sudangrass and sudangrass hybrids response to row spacing and plant maturity on yields and chemical composition. Agron. J. 65: 975-977. 
Worker, G. F. Jr., and V. L. Marble. 1968. Comparison of growth stages of sorghum forage types as to yield and chemical composition. Agron. J. 60: 669-671.

Zadoks, J. C., T. T. Chang, and C. F. Konzak. 1974. A decimal code for the growth stages of cereals. Weed Research 14: 415-421. 


\section{Appendix}

Appendix 1: Analysis of Soil samples collected prior to seeding in 2004 and 2005.

\begin{tabular}{|c|c|c|c|c|c|c|}
\hline Year & Block & $\mathrm{pH}$ & $P$ & $\mathrm{~K}$ & $\mathrm{Ca}$ & $\mathrm{Mg}$ \\
\hline & & & & $-\mathrm{kg} \mathrm{h}$ & & ---- \\
\hline 2004 & 1 & 6.6 & 57 & 171 & 4635 & 542 \\
\hline 2004 & 2 & 6.5 & 59 & 145 & 3496 & 424 \\
\hline 2004 & 3 & 6.6 & 61 & 180 & 3846 & 489 \\
\hline 2004 & 4 & 6.5 & 67 & 194 & 3848 & 485 \\
\hline 2005 & 1 & 6.1 & 48 & 258 & 3357 & 680 \\
\hline 2005 & 2 & 6.1 & 42 & 199 & 3327 & 595 \\
\hline 2005 & 3 & 5.9 & 35 & 215 & 2457 & 428 \\
\hline 2005 & 4 & 6.1 & 44 & 190 & 2815 & 517 \\
\hline
\end{tabular}

Appendix 2a: Economic returns from summer harvest of naturalized pasture with $0 \mathrm{~kg} \mathrm{ha}^{-1} \mathrm{~N}$.

\begin{tabular}{|c|c|c|c|c|}
\hline Item & $\begin{array}{c}\text { Units } \\
\text { PRODUCTION }\end{array}$ & Quantity & Value & $\$ \mathrm{ha}^{-1}$ \\
\hline Yield & tons & 2.28 & $\$ 60.00$ & $\$ 136.86$ \\
\hline TOTAL CROP VALUE & & & & $\$ 136.86$ \\
\hline \multicolumn{5}{|c|}{ VARIABLE COSTS } \\
\hline \multicolumn{5}{|l|}{ ESTABLISHMENT COSTS } \\
\hline Fertilizer $\mathrm{N}$ & $\mathrm{kg}$ & 0 & $\$ 0.81$ & $\$ 0.00$ \\
\hline TOTAL VARIABLE COST & & & & $\$ 0.00$ \\
\hline INTEREST ON INVESTMENT & & & $7.0 \%$ & $\$ 0.00$ \\
\hline \multirow[t]{2}{*}{ Fertilizer spreading } & /ha & 0 & 12.50 & 0.00 \\
\hline & TOTAL COSTS & & & 0.00 \\
\hline \multicolumn{2}{|c|}{ Net return over Variable Costs $\left(\$ h^{-1}\right)$} & & & 136.86 \\
\hline \multicolumn{2}{|c|}{ Break-Even for Variable Costs $\left(\$\right.$ ton $\left.^{-1}\right)$} & & 60.00 & \\
\hline
\end{tabular}


Appendix $2 \mathrm{~b}$ : Economic returns from summer harvest of naturalized pasture with $50 \mathrm{~kg} \mathrm{ha}^{-1} \mathrm{~N}$.

\begin{tabular}{lcrrr}
\hline Item & $\begin{array}{c}\text { Units } \\
\text { PRODUCTION }\end{array}$ & Quantity & Value & $\$$ ha $^{-1}$ \\
\hline Yield & tons & 2.55 & $\$ 60.00$ & $\$ 152.94$ \\
TOTAL CROP VALUE & & & & $\$ 152.94$ \\
& VARIABLE COSTS & & & \\
VARIABLE COSTS & $\mathrm{kg}$ & 0 & $\$ 1.57$ & $\$ 0.00$ \\
$\quad$ Seed & $\mathrm{kg}$ & 50 & $\$ 0.81$ & $\$ 40.70$ \\
Fertilizer N & ha $^{-1}$ & 1 & $\$ 12.50$ & $\$ 12.50$ \\
$\quad$ Apply Fertilizer & & & & $\$ 53.20$ \\
TOTAL COST & & & $7.0 \%$ & $\$ 1.86$ \\
INTEREST ON INVESTMENT & & & & $\$ 55.06$ \\
TOTAL VARIABLE COST & & & & 97.88 \\
Net return over Variable Costs $\left(\$\right.$ ha $\left.^{-1}\right)$ & 38.40 & \\
Break-Even for Variable Costs $\left(\$\right.$ ton $\left.^{-1}\right)$ & & &
\end{tabular}

Appendix 2c: Economic returns from summer harvest of naturalized pasture with $100 \mathrm{~kg} \mathrm{ha}^{-1} \mathrm{~N}$.

\begin{tabular}{|c|c|c|c|c|}
\hline Item & Units & Quantity & Value & $\$ \mathrm{ha}^{-1}$ \\
\hline \multicolumn{5}{|c|}{ PRODUCTION } \\
\hline Yield & tons & 2.85 & $\$ 60.00$ & $\$ 171.24$ \\
\hline TOTAL CROP VALUE & & & & $\$ 171.24$ \\
\hline \multicolumn{5}{|c|}{ VARIABLE COSTS } \\
\hline ESTABLISHMENT COSTS & & & & \\
\hline Seed & $\mathrm{kg}$ & 0 & $\$ 1.57$ & $\$ 0.00$ \\
\hline Fertilizer $\mathrm{N}$ & $\mathrm{kg}$ & 100 & $\$ 0.81$ & $\$ 81.40$ \\
\hline Apply Fertilizer & $\mathrm{ha}^{-1}$ & 1 & $\$ 12.50$ & $\$ 12.50$ \\
\hline TOTAL COST & & & & $\$ 93.90$ \\
\hline INTEREST ON INVESTMENT & & & $7.0 \%$ & $\$ 3.29$ \\
\hline TOTAL VARIABLE COST & & & & $\$ 97.19$ \\
\hline Net return over Variable Costs $\left(\$ \mathrm{ha}^{-1}\right)$ & & & & 74.05 \\
\hline Break-Even for Variable Costs $\left(\$\right.$ ton $\left.^{-1}\right)$ & & & & 25.95 \\
\hline
\end{tabular}


Appendix 2d: Economic returns from pearl millet established after burning and received $0 \mathrm{~kg} \mathrm{~N} \mathrm{ha}^{-1}$.

\begin{tabular}{|c|c|c|c|c|}
\hline PRODL & $\begin{array}{l}\text { Units } \\
\text { ON }\end{array}$ & Quantity & Value & $\$$ ha $^{-1}$ \\
\hline Harvests/year & times & 1.00 & & \\
\hline Yield & tons & 2.84 & $\$ 60.00$ & $\$ 170.16$ \\
\hline \multicolumn{5}{|c|}{ VARIABLE COSTS } \\
\hline ESTABLISHMENT COSTS & & & & \\
\hline Seed & $\mathrm{kg}$ & 45.0 & $\$ 1.57$ & $\$ 70.65$ \\
\hline propane & gal & 15.0 & $\$ 1.89$ & $\$ 28.35$ \\
\hline No-till Plant & $\mathrm{ha}^{-1}$ & 1.0 & $\$ 37.50$ & $\$ 37.50$ \\
\hline Apply Burn & $\mathrm{ha}^{-1}$ & 1.0 & $\$ 21.43$ & $\$ 21.43$ \\
\hline TOTAL ESTABLISHMENT COST & & & & $\$ 157.93$ \\
\hline INTEREST ON INVESTMENT & & & $7.0 \%$ & $\$ 5.53$ \\
\hline TOTAL VARIABLE COST & & & & $\$ 163.46$ \\
\hline Net return over Variable Costs $\left(\$\right.$ ha $\left.^{-1}\right)$ & & & & 6.70 \\
\hline Break-Even for Variable Costs $\left(\$\right.$ ton $\left.^{-1}\right)$ & & & 2.36 & \\
\hline
\end{tabular}

Appendix 2e: Economic returns from pearl millet established after burning and received $50 \mathrm{~kg} \mathrm{~N} \mathrm{ha}^{-1}$.

\begin{tabular}{|c|c|c|c|c|}
\hline Item & Units & Quantity & Value & $\$ \mathrm{ha}^{-1}$ \\
\hline \multicolumn{5}{|c|}{ PRODUCTION } \\
\hline Yield & tons & 3.40 & $\$ 60.00$ & $\$ 204.18$ \\
\hline TOTAL CROP VALUE & & & & $\$ 204.18$ \\
\hline \multicolumn{5}{|c|}{ VARIABLE COSTS } \\
\hline ESTABLISHMENT COSTS & & & & \\
\hline Seed & $\mathrm{kg}$ & 45.0 & $\$ 1.57$ & $\$ 70.65$ \\
\hline Fertilizer $\mathrm{N}$ & $\mathrm{kg}$ & 50.0 & $\$ 0.81$ & $\$ 40.70$ \\
\hline propane & gal & 15.0 & $\$ 1.89$ & $\$ 28.35$ \\
\hline No-till Plant & $\mathrm{ha}^{-1}$ & 1.0 & $\$ 37.50$ & $\$ 37.50$ \\
\hline Apply Fertilizer & $\mathrm{ha}^{-1}$ & 1.0 & $\$ 12.50$ & $\$ 12.50$ \\
\hline Apply Burn & $\mathrm{ha}^{-1}$ & 1.0 & $\$ 21.43$ & $\$ 21.43$ \\
\hline TOTAL ESTABLISHMENT COST & & & & $\$ 189.70$ \\
\hline INTEREST ON INVESTMENT & & & $7.0 \%$ & $\$ 6.64$ \\
\hline TOTAL VARIABLE COST & & & & $\$ 196.34$ \\
\hline Net return over Variable Costs $\left(\$\right.$ ha $\left.^{-1}\right)$ & & & & 7.84 \\
\hline Break-Even for Variable Costs $\left(\$\right.$ ton $\left.^{-1}\right)$ & & & 2.30 & \\
\hline
\end{tabular}


Appendix 2f: Economic returns from pearl millet established after burning and received $100 \mathrm{~kg} \mathrm{~N} \mathrm{ha}^{-1}$.

\begin{tabular}{|c|c|c|c|c|}
\hline Item & Units & Quantity & Value & $\$$ ha $^{-1}$ \\
\hline \multicolumn{5}{|c|}{ PRODUCTION } \\
\hline Yield & tons & 3.84 & $\$ 60.00$ & $\$ 230.10$ \\
\hline TOTAL CROP VALUE & & & & $\$ 230.10$ \\
\hline \multicolumn{5}{|c|}{ VARIABLE COSTS } \\
\hline ESTABLISHMENT COSTS & & & & \\
\hline Seed & $\mathrm{kg}$ & 45.0 & $\$ 1.57$ & $\$ 70.65$ \\
\hline Fertilizer $\mathrm{N}$ & $\mathrm{kg}$ & 100.0 & $\$ 0.81$ & $\$ 81.40$ \\
\hline propane & gal & 15.0 & $\$ 1.89$ & $\$ 28.35$ \\
\hline No-till Plant & $\mathrm{ha}^{-1}$ & 1.0 & $\$ 37.50$ & $\$ 37.50$ \\
\hline Apply Fertilizer & $\mathrm{ha}^{-1}$ & 1.0 & $\$ 12.50$ & $\$ 12.50$ \\
\hline Apply Burn & $\mathrm{ha}^{-1}$ & 1.0 & $\$ 21.43$ & $\$ 21.43$ \\
\hline TOTAL ESTABLISHMENT COST & & & & $\$ 251.83$ \\
\hline INTEREST ON INVESTMENT & & & $7.0 \%$ & $\$ 8.81$ \\
\hline TOTAL VARIABLE COST & & & & $\$ 260.64$ \\
\hline Net return over Variable Costs $\left(\$ h^{-1}\right)$ & & & & -30.54 \\
\hline Break-Even for Variable Costs $\left(\$\right.$ ton $\left.^{-1}\right)$ & & & -7.96 & \\
\hline
\end{tabular}

Appendix 2g: Economic returns from pearl millet established after glyphosate and received $0 \mathrm{~kg} \mathrm{~N} \mathrm{ha}^{-1}$.

\begin{tabular}{lcrrr}
\hline Item & $\begin{array}{c}\text { Units } \\
\text { PRODUCTION }\end{array}$ & Quantity & Value & $\$$ ha $^{-1}$ \\
\hline $\begin{array}{l}\text { Yield } \\
\text { TOTAL CROP VALUE }\end{array}$ & tons & 2.98 & $\$ 60.00$ & $\$ 178.92$ \\
& & & & $\$ 178.92$ \\
ESTABLISHMENT COSTS & VARIABLE COSTS & & & \\
Seed & kg & 45.0 & $\$ 1.57$ & $\$ 70.65$ \\
Herbicide & quarts ha & & \\
No-till Plant & ha $^{-1}$ & 0.6 & $\$ 67.20$ & $\$ 42.00$ \\
Apply Herbicide & ha $^{-1}$ & 1.0 & $\$ 37.50$ & $\$ 37.50$ \\
TOTAL ESTABLISHMENT COST & & 1.0 & $\$ 5.13$ & $\$ 5.13$ \\
INTEREST ON INVESTMENT & & & & $\$ 155.28$ \\
TOTAL VARIABLE COST & & & $7.0 \%$ & $\$ 5.43$ \\
Net return over Variable Costs $\left(\$\right.$ ha $\left.^{-1}\right)$ & & & & $\$ 160.71$ \\
Break-Even for Variable Costs $\left(\$\right.$ ton $\left.^{-1}\right)$ & & & 6.11 & \\
\hline
\end{tabular}


Appendix 2h: Economic returns from pearl millet established after glyphosate and received $50 \mathrm{~kg} \mathrm{~N} \mathrm{ha}^{-1}$.

\begin{tabular}{|c|c|c|c|c|}
\hline Item & $\begin{array}{l}\text { Units } \\
\text { ION }\end{array}$ & Quantity & Value & $\$ h^{-1}$ \\
\hline Yield & tons & 3.67 & $\$ 60.00$ & $\$ 220.44$ \\
\hline TOTAL CROP VALUE & & & & $\$ 220.44$ \\
\hline \multicolumn{5}{|c|}{ VARIABLE COSTS } \\
\hline ESTABLISHMENT COSTS & & & & \\
\hline Seed & $\mathrm{kg}$ & 45.0 & $\$ 1.57$ & $\$ 70.65$ \\
\hline Fertilizer $\mathrm{N}$ & $\mathrm{kg}$ & 50.0 & $\$ 0.81$ & $\$ 40.70$ \\
\hline Herbicide & ${ }_{1}^{\text {quarts ha }}$ & 0.6 & $\$ 67.20$ & $\$ 42.00$ \\
\hline No-till Plant & $\mathrm{ha}^{-1}$ & 1.0 & $\$ 37.50$ & $\$ 37.50$ \\
\hline Apply Fertilizer & $\mathrm{ha}^{-1}$ & 1.0 & $\$ 12.50$ & $\$ 12.50$ \\
\hline Apply Herbicide & $\mathrm{ha}^{-1}$ & 1.0 & $\$ 5.13$ & $\$ 5.13$ \\
\hline TOTAL ESTABLISHMENT COST & & & & $\$ 208.48$ \\
\hline INTEREST ON INVESTMENT & & & $7.0 \%$ & $\$ 7.30$ \\
\hline TOTAL VARIABLE COST & & & & $\$ 215.78$ \\
\hline Net return over Variable Costs $\left(\$ \mathrm{ha}^{-1}\right)$ & & & & 4.66 \\
\hline Break-Even for Variable Costs $\left(\$\right.$ ton $\left.^{-1}\right)$ & & & 1.27 & \\
\hline
\end{tabular}

Appendix 2i: Economic returns from pearl millet established after glyphosate and received $100 \mathrm{~kg} \mathrm{~N} \mathrm{ha}^{-1}$.

\begin{tabular}{lcrrr}
\hline Item & $\begin{array}{c}\text { Units } \\
\text { PRODUCTION }\end{array}$ & Quantity & Value & $\$$ ha $^{-1}$ \\
\hline $\begin{array}{l}\text { Yield } \\
\text { TOTAL CROP VALUE }\end{array}$ & tons & 5.16 & $\$ 60.00$ & $\$ 309.48$ \\
& & & & $\$ 309.48$ \\
ESTABLISHMENT COSTS & VARIABLE COSTS & & & \\
Seed & $\mathrm{kg}$ & 45.0 & $\$ 1.57$ & $\$ 70.65$ \\
Fertilizer N & $\mathrm{kg}$ & 100.0 & $\$ 0.81$ & $\$ 81.40$ \\
Herbicide & quarts ha & & \\
No-till Plant & ha $^{-1}$ & 2.5 & $\$ 16.80$ & $\$ 42.00$ \\
Apply Fertilizer & ha $^{-1}$ & 1.0 & $\$ 37.50$ & $\$ 37.50$ \\
Apply herbicide & & 1.0 & $\$ 12.50$ & $\$ 12.50$ \\
TOTAL ESTABLISHMENT COST & & 1.0 & $\$ 5.13$ & $\$ 5.13$ \\
INTEREST ON INVESTMENT & & & $7.0 \%$ & $\$ 249.18$ \\
TOTAL VARIABLE COST & & & & $\$ 257.72$ \\
Net return over Variable Costs $\left(\$\right.$ ha $\left.^{-1}\right)$ & & & 10.00 & \\
Break-Even for Variable Costs $\left(\$\right.$ ton $\left.^{-1}\right)$ & & & & 51.58 \\
\hline
\end{tabular}


Appendix 2j: Economic returns from sudangrass established after burning and received $0 \mathrm{~kg} \mathrm{~N} \mathrm{ha}^{-1}$.

\begin{tabular}{|c|c|c|c|c|}
\hline PROL & $\begin{array}{l}\text { Units } \\
\text { N }\end{array}$ & Quantity & Value & $\$ \mathrm{ha}^{-1}$ \\
\hline Yield & tons & 3.07 & $\$ 60.00$ & $\$ 184.14$ \\
\hline TOTAL CROP VALUE & & & & $\$ 184.14$ \\
\hline \multicolumn{5}{|c|}{ VARIABLE COSTS } \\
\hline ESTABLISHMENT COSTS & & & & \\
\hline Seed & $\mathrm{kg}$ & 78.0 & $\$ 2.11$ & $\$ 164.74$ \\
\hline No-till Plant & $\mathrm{ha}^{-1}$ & 1.0 & $\$ 37.50$ & $\$ 37.50$ \\
\hline Propane & gal & 15.0 & $\$ 1.89$ & $\$ 28.35$ \\
\hline Apply Burn & $\mathrm{ha}^{-1}$ & 1.0 & $\$ 21.43$ & $\$ 21.43$ \\
\hline TOTAL ESTABLISHMENT COST & & & & $\$ 252.02$ \\
\hline INTEREST ON INVESTMENT & & & $7.0 \%$ & $\$ 8.82$ \\
\hline TOTAL VARIABLE COST & & & & $\$ 260.84$ \\
\hline Net return over Variable Costs $\left(\$ \mathrm{ha}^{-1}\right)$ & & & & -76.70 \\
\hline Break-Even for Variable Costs $\left(\$\right.$ ton $\left.^{-1}\right)$ & & & -24.99 & \\
\hline
\end{tabular}

Appendix 2k: Economic returns from sudangrass established after burning and received $50 \mathrm{~kg} \mathrm{~N} \mathrm{ha}^{-1}$.

\begin{tabular}{|c|c|c|c|c|}
\hline \multicolumn{4}{|c|}{ PRODUCTION } & $\$ \mathrm{ha}^{-1}$ \\
\hline Yield & tons & 3.61 & $\$ 60.00$ & $\$ 216.36$ \\
\hline TOTAL CROP VALUE & & & & $\$ 216.36$ \\
\hline \multicolumn{5}{|c|}{ VARIABLE COSTS } \\
\hline ESTABLISHMENT COSTS & & & & \\
\hline Seed & $\mathrm{kg}$ & 78.0 & $\$ 2.11$ & $\$ 164.74$ \\
\hline Fertilizer $\mathrm{N}$ & $\mathrm{kg}$ & 50.0 & $\$ 0.81$ & $\$ 40.70$ \\
\hline propane & gal & 15.0 & $\$ 1.89$ & $\$ 28.35$ \\
\hline No-till Plant & $\mathrm{ha}^{-1}$ & 1.0 & $\$ 37.50$ & $\$ 37.50$ \\
\hline Apply Fertilizer & $\mathrm{ha}^{-1}$ & 1.0 & $\$ 12.50$ & $\$ 12.50$ \\
\hline Apply burn & $\mathrm{ha}^{-1}$ & 1.0 & $\$ 21.43$ & $\$ 21.43$ \\
\hline TOTAL ESTABLISHMENT COST & & & & $\$ 305.22$ \\
\hline INTEREST ON INVESTMENT & & & $7.0 \%$ & $\$ 10.68$ \\
\hline TOTAL VARIABLE COST & & & & $\$ 315.90$ \\
\hline Net return over Variable Costs $\left(\$ \mathrm{ha}^{-1}\right)$ & & & & -99.54 \\
\hline Break-Even for Variable Costs $\left(\$\right.$ ton $\left.^{-1}\right)$ & & & -27.60 & \\
\hline
\end{tabular}


Appendix 2l: Economic returns from sudangrass established after burning and received $100 \mathrm{~kg} \mathrm{~N} \mathrm{ha}^{-1}$.

\begin{tabular}{|c|c|c|c|c|}
\hline Item & Units & Quantity & Value & $\$ h^{-1}$ \\
\hline \multicolumn{5}{|c|}{ PRODUCTION } \\
\hline Yield & tons & 4.14 & $\$ 60.00$ & $\$ 248.46$ \\
\hline TOTAL CROP VALUE & & & & $\$ 248.46$ \\
\hline \multicolumn{5}{|c|}{ VARIABLE COSTS } \\
\hline ESTABLISHMENT COSTS & & & & \\
\hline Seed & $\mathrm{kg}$ & 78.0 & $\$ 2.11$ & $\$ 164.74$ \\
\hline Fertilizer $\mathrm{N}$ & $\mathrm{kg}$ & 100.0 & $\$ 0.81$ & $\$ 81.40$ \\
\hline propane & gal & 15.0 & $\$ 1.89$ & $\$ 28.35$ \\
\hline No-till Plant & $\mathrm{ha}^{-1}$ & 1.0 & $\$ 37.50$ & $\$ 37.50$ \\
\hline Apply Fertilizer & $\mathrm{ha}^{-1}$ & 1.0 & $\$ 12.50$ & $\$ 12.50$ \\
\hline Apply burn & $\mathrm{ha}^{-1}$ & 1.0 & $\$ 21.43$ & $\$ 21.43$ \\
\hline TOTAL ESTABLISHMENT COST & & & & $\$ 345.92$ \\
\hline INTEREST ON INVESTMENT & & & $7.0 \%$ & $\$ 12.11$ \\
\hline TOTAL VARIABLE COST & & & & $\$ 358.02$ \\
\hline Net return over Variable Costs $\left(\$\right.$ ha $\left.^{-1}\right)$ & & & & -109.56 \\
\hline Break-Even for Variable Costs $\left(\$\right.$ ton $\left.^{-1}\right)$ & & & -26.46 & \\
\hline
\end{tabular}

Appendix $2 \mathrm{~m}$ : Economic returns from sudangrass established after glyphosate and received $0 \mathrm{~kg} \mathrm{~N} \mathrm{ha}^{-1}$.

\begin{tabular}{|c|c|c|c|c|}
\hline PRODUC & $\begin{array}{l}\text { Units } \\
\text { rION }\end{array}$ & Quantity & Value & $\$ h^{-1}$ \\
\hline Yield & tons & 5.98 & $\$ 60.00$ & $\$ 358.92$ \\
\hline TOTAL CROP VALUE & & & & $\$ 358.92$ \\
\hline \multicolumn{5}{|c|}{ VARIABLE COSTS } \\
\hline ESTABLISHMENT COSTS & & & & \\
\hline Seed & $\mathrm{kg}$ & 78.0 & $\$ 2.11$ & $\$ 164.74$ \\
\hline Herbicide & quarts ha ${ }^{-1}$ & 2.5 & $\$ 16.80$ & $\$ 42.00$ \\
\hline No-till Plant & $\mathrm{ha}^{-1}$ & 1.0 & $\$ 37.50$ & $\$ 37.50$ \\
\hline Apply herbicide & $\mathrm{ha}^{-1}$ & 1.0 & $\$ 5.13$ & $\$ 5.13$ \\
\hline TOTAL ESTABLISHMENT COST & & & & $\$ 249.37$ \\
\hline INTEREST ON INVESTMENT & & & $7.0 \%$ & $\$ 8.73$ \\
\hline TOTAL ANNUAL COST OF ESTABLISHMENT & & & & $\$ 258.09$ \\
\hline Net return over Variable Costs $\left(\$\right.$ ha $\left.^{-1}\right)$ & & & & 100.83 \\
\hline Break-Even for Variable Costs $\left(\$\right.$ ton $\left.^{-1}\right)$ & & & 16.85 & \\
\hline
\end{tabular}


Appendix 2n: Economic returns from sudangrass established after glyphosate and received $50 \mathrm{~kg} \mathrm{~N} \mathrm{ha}^{-1}$.

\begin{tabular}{lcrrr}
\hline Item & $\begin{array}{c}\text { Units } \\
\text { PRODUCTION }\end{array}$ & Quantity & Value & $\$$ ha $^{-1}$ \\
\hline $\begin{array}{l}\text { Yield } \\
\text { TOTAL CROP VALUE }\end{array}$ & tons & 6.29 & $\$ 60.00$ & $\$ 377.58$ \\
& & & & $\$ 377.58$ \\
ESTABLISHMENT COSTS & VARIABLE COSTS & & & \\
Seed & $\mathrm{kg}$ & 78.0 & $\$ 2.11$ & $\$ 164.74$ \\
Fertilizer N & $\mathrm{kg}$ & 50.0 & $\$ 0.81$ & $\$ 40.70$ \\
Herbicide & quarts ha & & \\
No-till Plant & ha $^{-1}$ & 2.5 & $\$ 16.80$ & $\$ 42.00$ \\
Apply Fertilizer & ha $^{-1}$ & 1.0 & $\$ 37.50$ & $\$ 37.50$ \\
Apply herbicide & ha $^{-1}$ & 1.0 & $\$ 12.50$ & $\$ 12.50$ \\
TOTAL ESTABLISHMENT COST & & 1.0 & $\$ 5.13$ & $\$ 5.13$ \\
INTEREST ON INVESTMENT & & & & $\$ 302.57$ \\
TOTAL VARIABLE COST & & & $7.0 \%$ & $\$ 10.59$ \\
Net return over Variable Costs $\left(\$\right.$ ha $\left.^{-1}\right)$ & & & $\$ 313.16$ \\
Break-Even for Variable Costs $\left(\$\right.$ ton $\left.^{-1}\right)$ & & & 10.24 & \\
\hline
\end{tabular}

Appendix 2p: Economic returns from sudangrass established after glyphosate and received $100 \mathrm{~kg} \mathrm{~N} \mathrm{ha}^{-1}$.

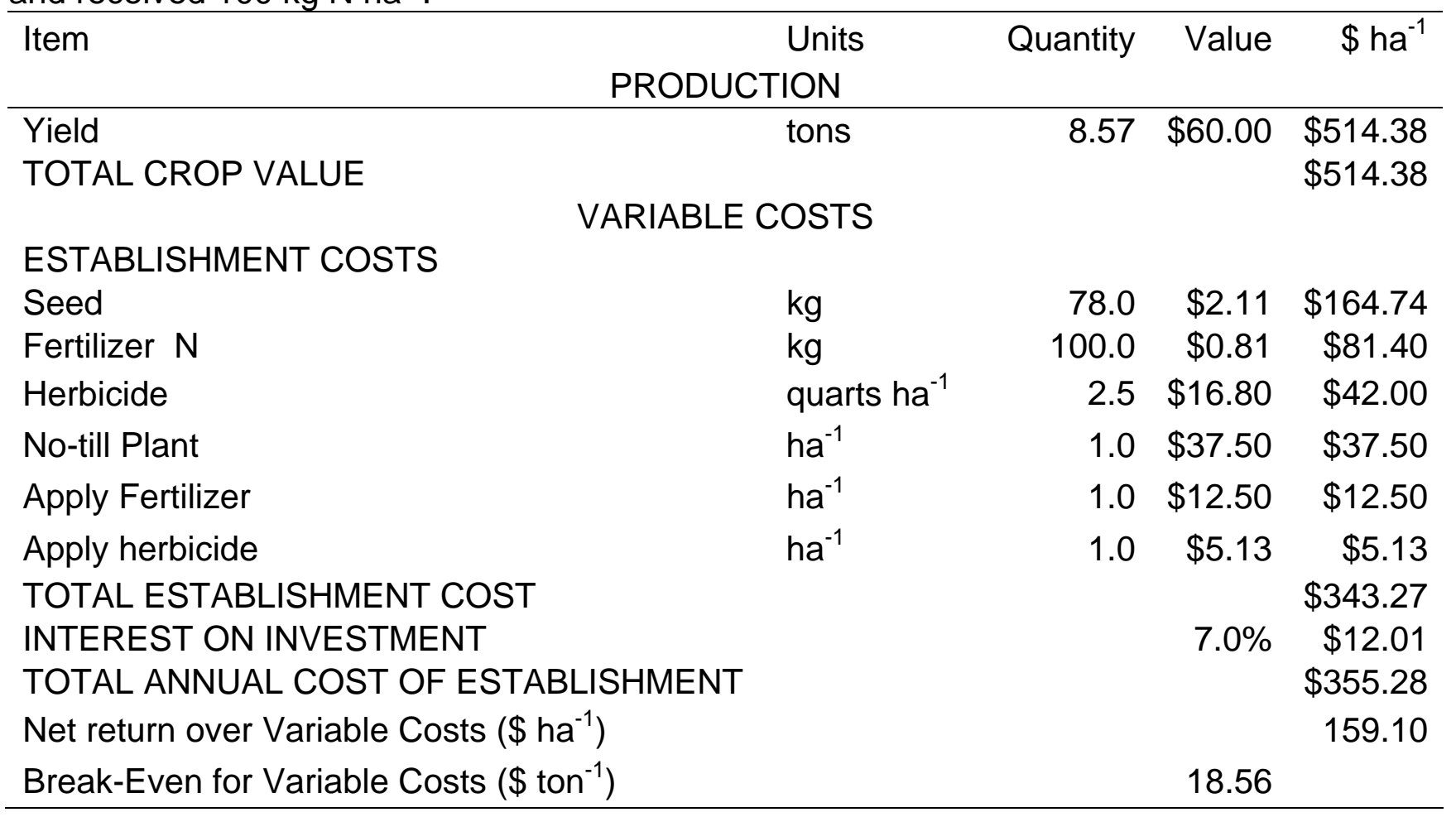


Appendix 3a: Economic returns from fall harvest of naturalized pasture with $0 \mathrm{~kg}$ $\mathrm{ha}^{-1} \mathrm{~N}$.

\begin{tabular}{|c|c|c|c|c|}
\hline Item & $\begin{array}{c}\text { Units } \\
\text { PRODUCTION }\end{array}$ & Quantity & Value & $\$$ ha $^{-1}$ \\
\hline Yield & tons & 2.24 & $\$ 60.00$ & $\$ 134.64$ \\
\hline \multicolumn{5}{|c|}{ VARIABLE COSTS } \\
\hline ESTABLISHMENT COS & & & & \\
\hline Fertilizer $\mathrm{N}$ & $\mathrm{kg}$ & 0 & $\$ 0.81$ & $\$ 0.00$ \\
\hline Apply Fertilizer & $\mathrm{ha}^{-1}$ & 0 & $\$ 12.50$ & $\$ 0.00$ \\
\hline \multicolumn{2}{|c|}{ TOTAL ESTABLISHMENT COST } & & & $\$ 0.00$ \\
\hline \multicolumn{2}{|c|}{ INTEREST ON INVESTMENT } & & $7.0 \%$ & $\$ 0.00$ \\
\hline \multicolumn{2}{|c|}{ TOTAL VARIABLE COST ha ${ }^{-1}$} & & & $\$ 0.00$ \\
\hline \multicolumn{2}{|c|}{ Net return over Variable Costs $\left(\$ \mathrm{ha}^{-1}\right)$} & & & 134.64 \\
\hline \multicolumn{2}{|c|}{ Break-Even for Variable Costs $\left(\$\right.$ ton $\left.^{-1}\right)$} & & 60.00 & \\
\hline
\end{tabular}

Appendix 3b: Economic returns from fall harvest of naturalized pasture with $50 \mathrm{~kg}$ $\mathrm{ha}^{-1} \mathrm{~N}$.

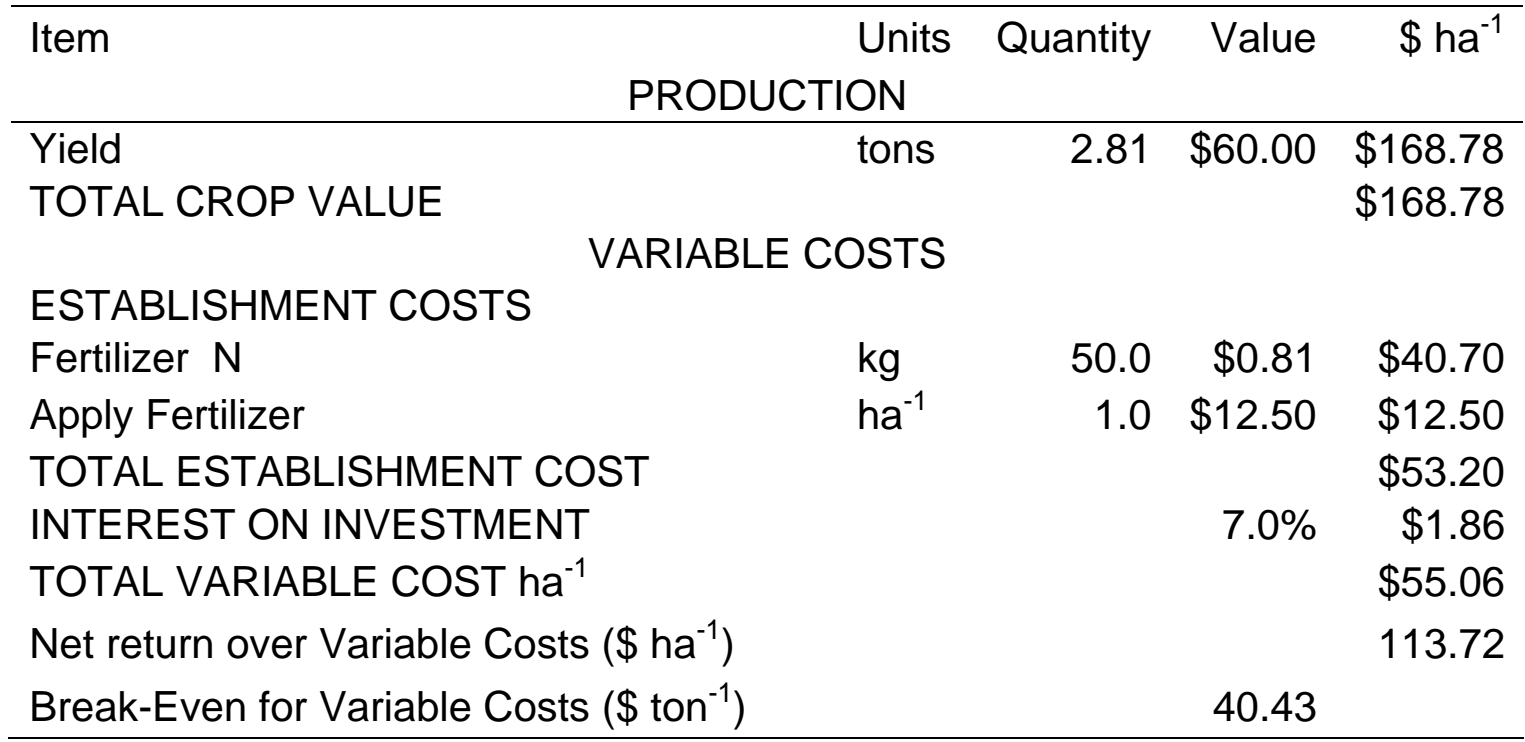


Appendix 3c: Economic returns from fall harvest of naturalized pasture with 100 $\mathrm{kg} \mathrm{ha}^{-1} \mathrm{~N}$.

\begin{tabular}{|c|c|c|c|c|}
\hline PROD & $\begin{array}{l}\text { Units } \\
\text { ION }\end{array}$ & Quantity & Value & $\$ h^{-1}$ \\
\hline Yield & tons & 2.78 & $\$ 60.00$ & $\$ 166.74$ \\
\hline TOTAL CROP VALUE & & & & $\$ 166.74$ \\
\hline \multicolumn{5}{|c|}{ VARIABLE COSTS } \\
\hline ESTABLISHMENT COSTS & & & & \\
\hline Fertilizer $\mathrm{N}$ & $\mathrm{kg}$ & 100.0 & $\$ 0.81$ & $\$ 81.40$ \\
\hline Apply Fertilizer & $\mathrm{ha}^{-1}$ & 1.0 & $\$ 12.50$ & $\$ 12.50$ \\
\hline TOTAL ESTABLISHMENT COST & & & & $\$ 93.90$ \\
\hline INTEREST ON INVESTMENT & & & $7.0 \%$ & $\$ 3.29$ \\
\hline TOTAL VARIABLE COST ha ${ }^{-1}$ & & & & $\$ 97.19$ \\
\hline Net return over Variable Costs $\left(\$ \mathrm{ha}^{-1}\right)$ & & & & 69.55 \\
\hline Break-Even for Variable Costs $\left(\$\right.$ ton $\left.^{-1}\right)$ & & & 34.97 & \\
\hline
\end{tabular}

Appendix 3d: Economic returns from fall harvest of turnip-annual ryegrass mix established after burning and received $0 \mathrm{~kg} \mathrm{ha}^{-1} \mathrm{~N}$ on plots that had previously pearl millet in summer.

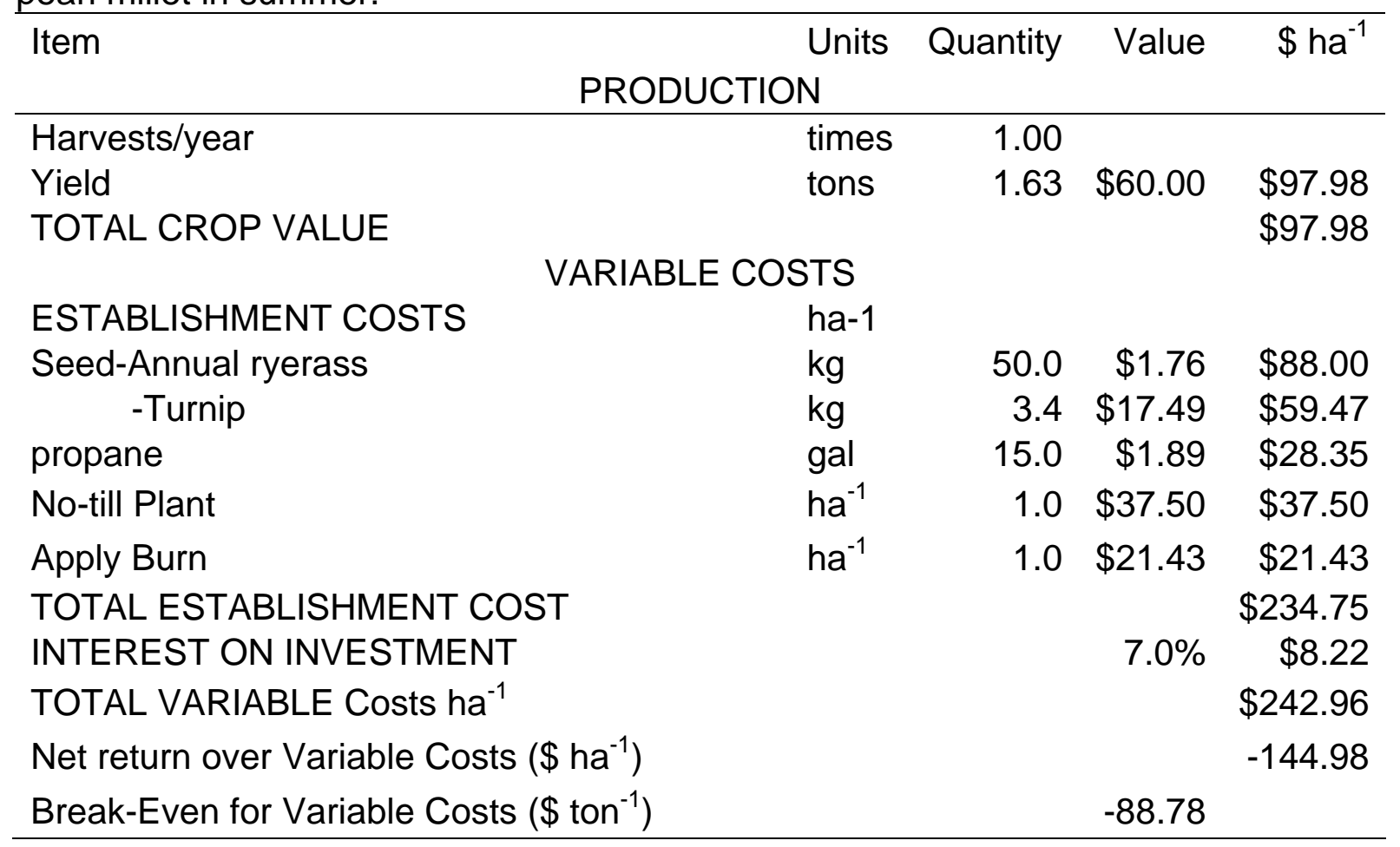


Appendix 3e: Economic returns from fall harvest of triticale established after burning and received $0 \mathrm{~kg} \mathrm{ha}^{-1} \mathrm{~N}$ on plots that had previously pearl millet in summer.

\begin{tabular}{|c|c|c|c|c|}
\hline Item & Units & Quantity & Value & $\$ h^{-1}$ \\
\hline Harvests/year & times & 1.00 & & \\
\hline Yield & tons & 1.28 & $\$ 60.00$ & $\$ 76.80$ \\
\hline \multicolumn{5}{|c|}{ VARIABLE COSTS } \\
\hline ESTABLISHMENT COSTS & & & & \\
\hline Seed & $\mathrm{kg}$ & 70.0 & $\$ 0.55$ & $\$ 38.50$ \\
\hline propane & gal & 15.0 & $\$ 1.89$ & $\$ 28.35$ \\
\hline No-till Plant & $\mathrm{ha}^{-1}$ & 1.0 & $\$ 37.50$ & $\$ 37.50$ \\
\hline Apply Burn & $\mathrm{ha}^{-1}$ & 1.0 & $\$ 21.43$ & $\$ 21.43$ \\
\hline TOTAL ESTABLISHMENT COST & & & & $\$ 125.78$ \\
\hline INTEREST ON INVESTMENT & & & $7.0 \%$ & $\$ 4.40$ \\
\hline TOTAL VARIABLE COST ha ${ }^{-1}$ & & & & $\$ 130.18$ \\
\hline Net return over Variable Costs $\left(\$ \mathrm{ha}^{-1}\right)$ & & & & -53.38 \\
\hline Break-Even for Variable Costs $\left(\$\right.$ ton $\left.^{-1}\right)$ & & & -41.70 & \\
\hline
\end{tabular}


Appendix 3f: Economic returns from fall harvest of turnip-annual ryegrass mix established after burning and received $50 \mathrm{~kg} \mathrm{ha}^{-1}$ of $\mathrm{N}$ on plots that had previously pearl millet in summer.

\begin{tabular}{|c|c|c|c|c|}
\hline Item & Units & Quantity & Value & $\$ \mathrm{ha}^{-1}$ \\
\hline \multicolumn{5}{|c|}{ PRODUCTION } \\
\hline Yield & tons & 2.47 & $\$ 60.00$ & $\$ 148.26$ \\
\hline TOTAL CROP VALUE & & & & $\$ 148.26$ \\
\hline \multicolumn{5}{|c|}{ VARIABLE COSTS } \\
\hline ESTABLISHMENT COSTS & & & & \\
\hline Seed-Annual ryerass & $\mathrm{kg}$ & 50.0 & $\$ 1.76$ & $\$ 88.00$ \\
\hline -Turnip & $\mathrm{kg}$ & 3.4 & $\$ 17.49$ & $\$ 59.47$ \\
\hline Fertilizer N & $\mathrm{kg}$ & 50.0 & $\$ 0.81$ & $\$ 40.70$ \\
\hline Propane & gal & 15.0 & $\$ 1.89$ & $\$ 28.35$ \\
\hline No-till Plant & $\mathrm{ha}^{-1}$ & 1.0 & $\$ 37.50$ & $\$ 37.50$ \\
\hline Apply Fertilizer & $\mathrm{ha}^{-1}$ & 1.0 & $\$ 12.50$ & $\$ 12.50$ \\
\hline Apply Burn & $\mathrm{ha}^{-1}$ & 1.0 & $\$ 20.56$ & $\$ 20.56$ \\
\hline TOTAL ESTABLISHMENT COST & & & & $\$ 266.52$ \\
\hline INTEREST ON INVESTMENT & & & $7.0 \%$ & $\$ 9.33$ \\
\hline TOTAL VARIABLE COST ha ${ }^{-1}$ & & & & $\$ 275.84$ \\
\hline Net return over Variable Costs $\left(\$\right.$ ha $\left.^{-1}\right)$ & & & & -127.58 \\
\hline Break-Even for Variable Costs $\left(\$\right.$ ton $\left.^{-1}\right)$ & & & -51.63 & \\
\hline
\end{tabular}


Appendix 3g: Economic returns from fall harvest of triticale established after burning and received $50 \mathrm{~kg} \mathrm{ha}^{-1}$ of $\mathrm{N}$ on plots that had previously pearl millet in summer.

\begin{tabular}{|c|c|c|c|c|}
\hline Item & Units & Quantity & Value & $\$ \mathrm{ha}^{-1}$ \\
\hline \multicolumn{5}{|c|}{ PRODUCTION } \\
\hline Yield & tons & 1.92 & $\$ 60.00$ & $\$ 115.14$ \\
\hline TOTAL CROP VALUE & & & & $\$ 115.14$ \\
\hline \multicolumn{5}{|c|}{ VARIABLE COSTS } \\
\hline ESTABLISHMENT COSTS & & & & \\
\hline Seed & $\mathrm{kg}$ & 70.0 & $\$ 0.55$ & $\$ 38.50$ \\
\hline Fertilizer $\mathrm{N}$ & $\mathrm{kg}$ & 50.0 & $\$ 0.81$ & $\$ 40.70$ \\
\hline Propane & gal & 15.0 & $\$ 1.89$ & $\$ 28.35$ \\
\hline No-till Plant & $\mathrm{ha}^{-1}$ & 0.0 & $\$ 37.50$ & $\$ 0.00$ \\
\hline Apply Fertilizer & $\mathrm{ha}^{-1}$ & 1.0 & $\$ 12.50$ & $\$ 12.50$ \\
\hline Apply burn & $\mathrm{ha}^{-1}$ & 1.0 & $\$ 21.43$ & $\$ 21.43$ \\
\hline TOTAL ESTABLISHMENT COST & & & & $\$ 141.48$ \\
\hline INTEREST ON INVESTMENT & & & $7.0 \%$ & $\$ 4.95$ \\
\hline TOTAL VARIABLE COST ha ${ }^{-1}$ & & & & 146.43 \\
\hline Net return over Variable Costs $\left(\$ \mathrm{ha}^{-1}\right)$ & & & & -31.29 \\
\hline Break-Even for Variable Costs $\left(\$\right.$ ton $\left.^{-1}\right)$ & & & 76.31 & \\
\hline
\end{tabular}


Appendix 3h: Economic returns from fall harvest of turnip-annual ryegrass mix established after burning and received $100 \mathrm{~kg} \mathrm{ha}^{-1}$ of $\mathrm{N}$ on plots that had previously pearl millet in summer.

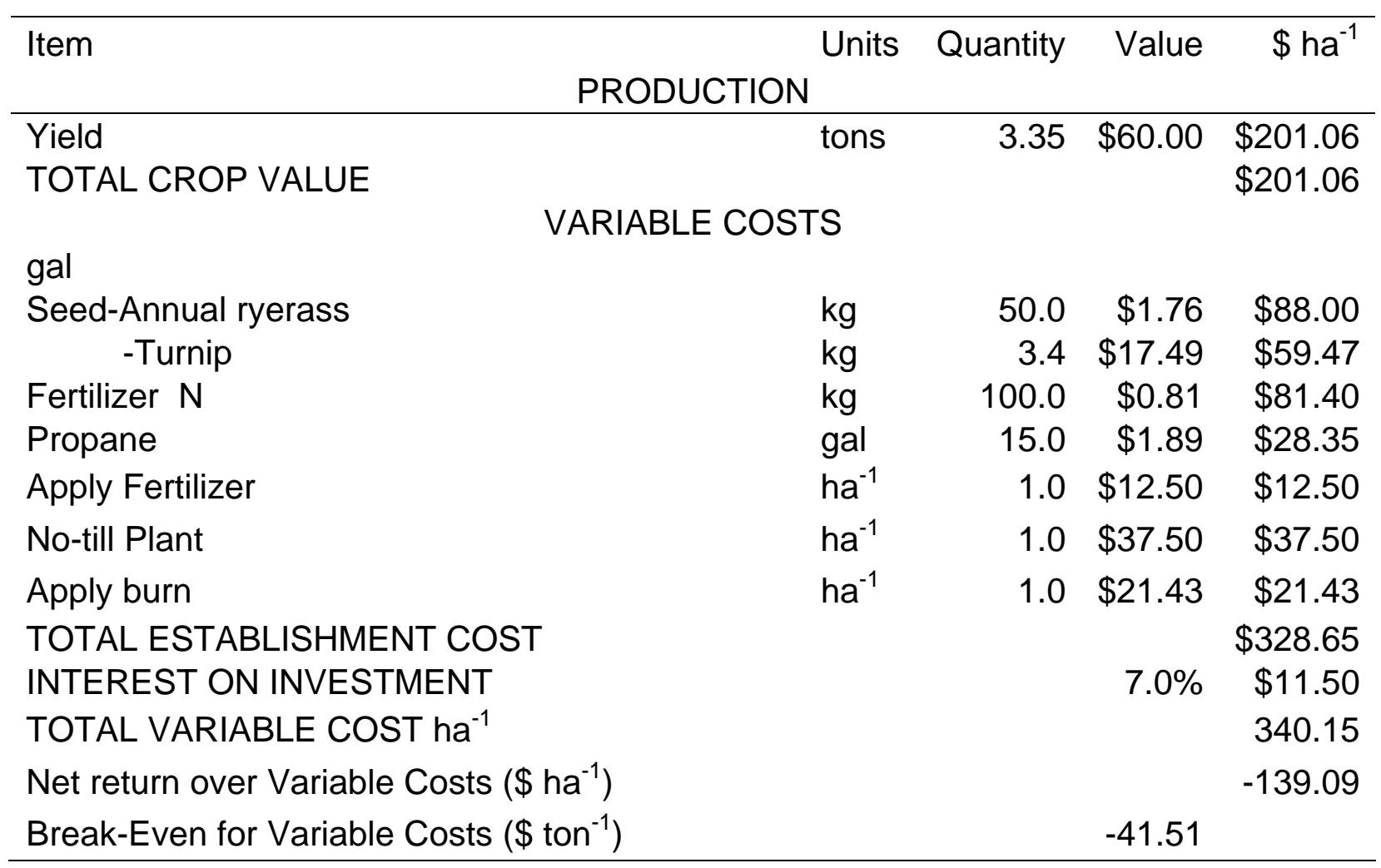


Appendix 3i: Economic returns from fall harvest of triticale established after burning and received $100 \mathrm{~kg} \mathrm{ha}^{-1}$ of $\mathrm{N}$ on plots that had previously pearl millet in summer.

\begin{tabular}{|c|c|c|c|c|}
\hline Item & Units & Quantity & Value & $\$ h^{-1}$ \\
\hline \multicolumn{5}{|c|}{ PRODUCTION } \\
\hline Yield & tons & 2.65 & $\$ 60.00$ & $\$ 158.70$ \\
\hline TOTAL CROP VALUE & & & & $\$ 158.70$ \\
\hline \multicolumn{5}{|c|}{ VARIABLE COSTS } \\
\hline ESTABLISHMENT COSTS & & & & \\
\hline Seed & $\mathrm{kg}$ & 70.0 & $\$ 0.55$ & $\$ 38.50$ \\
\hline Fertilizer $\mathrm{N}$ & $\mathrm{kg}$ & 100.0 & $\$ 0.81$ & $\$ 81.40$ \\
\hline Propane & gal & 15.0 & $\$ 1.89$ & $\$ 28.35$ \\
\hline No-till Plant & $\mathrm{ha}^{-1}$ & 1.0 & $\$ 37.50$ & $\$ 37.50$ \\
\hline Apply Fertilizer & $\mathrm{ha}^{-1}$ & 1.0 & $\$ 12.50$ & $\$ 12.50$ \\
\hline Apply burn & $\mathrm{ha}^{-1}$ & 1.0 & $\$ 21.43$ & $\$ 21.43$ \\
\hline TOTAL ESTABLISHMENT COST & & & & $\$ 198.25$ \\
\hline INTEREST ON INVESTMENT & & & $7.0 \%$ & $\$ 6.94$ \\
\hline TOTAL VARIABLE COST ha ${ }^{-1}$ & & & & 205.19 \\
\hline Net return over Variable Costs $\left(\$ \mathrm{ha}^{-1}\right)$ & & & & -46.49 \\
\hline Break-Even for Variable Costs $\left(\$\right.$ ton $\left.^{-1}\right)$ & & & -17.58 & \\
\hline
\end{tabular}


Appendix 3j: Economic returns from fall harvest of annual ryegrass-turnip mix established after glyphosate and received $0 \mathrm{~kg} \mathrm{ha}^{-1}$ of $\mathrm{N}$ on plots that had previously pearl millet in summer.

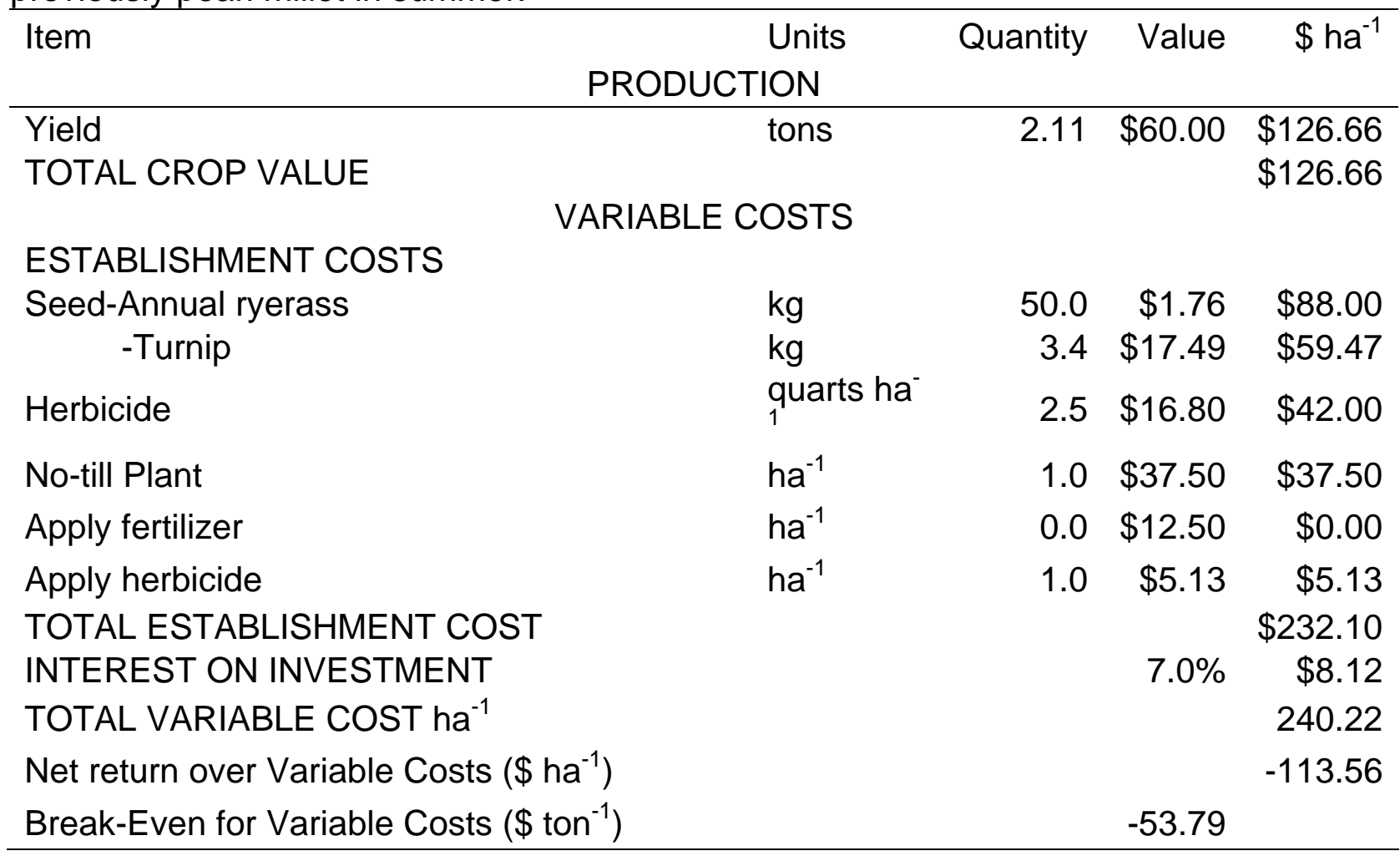


Appendix 3k: Economic returns from fall harvest of triticale established after glyphosate and received $0 \mathrm{~kg} \mathrm{ha}^{-1}$ of $\mathrm{N}$ on plots that had previously pearl millet in summer.

\begin{tabular}{|c|c|c|c|c|}
\hline Item & $\begin{array}{l}\text { Units } \\
\text { TION }\end{array}$ & Quantity & Value & $\$ h^{-1}$ \\
\hline Yield & tons & 1.54 & $\$ 60.00$ & $\$ 92.16$ \\
\hline TOTAL CROP VALUE & & & & $\$ 92.16$ \\
\hline \multicolumn{5}{|c|}{ VARIABLE COSTS } \\
\hline ESTABLISHMENT COSTS & & & & \\
\hline Seed & $\mathrm{kg}$ & 70.0 & $\$ 0.55$ & $\$ 38.50$ \\
\hline Herbicide & quarts ha ${ }^{-1}$ & 2.5 & $\$ 16.80$ & $\$ 42.00$ \\
\hline No-till Plant & $\mathrm{ha}^{-1}$ & 1.0 & $\$ 37.50$ & $\$ 37.50$ \\
\hline Apply herbicide & $\mathrm{ha}^{-1}$ & 1.0 & $\$ 5.13$ & $\$ 5.13$ \\
\hline TOTAL ESTABLISHMENT COST & & & & $\$ 118.00$ \\
\hline INTEREST ON INVESTMENT & & & $7.0 \%$ & $\$ 4.13$ \\
\hline TOTAL VARIABLE COSTS/ha & & & & 122.13 \\
\hline Net return over Variable Costs $\left(\$\right.$ ha $\left.^{-1}\right)$ & & & & -29.97 \\
\hline Break-Even for Variable Costs $\left(\$\right.$ ton $\left.^{-1}\right)$ & & & -19.51 & \\
\hline
\end{tabular}


Appendix 2: Economic returns from fall harvest of annual ryegrass-turnip mix established after glyphosate and received $50 \mathrm{~kg} \mathrm{ha}^{-1}$ of $\mathrm{N}$ on plots that had previously pearl millet in summer.

\begin{tabular}{lcrrr}
\hline Item & $\begin{array}{c}\text { Units } \\
\text { PRODUCTION }\end{array}$ & Quantity & Value & $\$$ ha $^{-1}$ \\
\hline $\begin{array}{l}\text { Yield } \\
\text { TOTAL CROP VALUE }\end{array}$ & tons & 3.38 & $\$ 60.00$ & $\$ 203.04$ \\
& & & & $\$ 203.04$ \\
ESTABLISHMENT COSTS & VARIABLE COSTS & & & \\
Seed-Annual ryerass & & & & \\
$\quad$-Turnip & $\mathrm{kg}$ & 50.0 & $\$ 1.76$ & $\$ 88.00$ \\
Fertilizer N & $\mathrm{kg}$ & 3.4 & $\$ 17.49$ & $\$ 59.47$ \\
Herbicide & $\mathrm{kg}$ & 50.0 & $\$ 0.81$ & $\$ 40.70$ \\
No-till Plant & quarts ha & 2.5 & $\$ 16.80$ & $\$ 42.00$ \\
Apply fertilizer & ha $^{-1}$ & 0.0 & $\$ 37.50$ & $\$ 0.00$ \\
Apply herbicide & ha $^{-1}$ & 1.0 & $\$ 12.50$ & $\$ 12.50$ \\
TOTAL ESTABLISHMENT COST & ha $^{-1}$ & 1.0 & $\$ 5.13$ & $\$ 5.13$ \\
INTEREST ON INVESTMENT & & & & $\$ 230.17$ \\
TOTAL VARIABLE COSTS/ha & & & $7.0 \%$ & $\$ 8.06$ \\
Net return over Variable Costs $\left(\$\right.$ ha $\left.^{-1}\right)$ & & & & 238.22 \\
Break-Even for Variable Costs $\left(\$\right.$ ton $\left.^{-1}\right)$ & & & -10.40 & \\
\hline
\end{tabular}


Appendix 31: Economic returns from fall harvest of triticale established after glyphosate and received $50 \mathrm{~kg} \mathrm{ha}^{-1}$ of $\mathrm{N}$ on plots that had previously pearl millet in summer.

\begin{tabular}{lcrrr}
\hline Item & $\begin{array}{c}\text { Units } \\
\text { PRODUCTION }\end{array}$ & Quantity & Value & $\$$ ha $^{-1}$ \\
\hline $\begin{array}{l}\text { Yield } \\
\text { TOTAL CROP VALUE }\end{array}$ & tons & 2.20 & $\$ 60.00$ & $\$ 132.18$ \\
& & & & $\$ 132.18$ \\
ESTABLISHMENT COSTS & VARIABLE COSTS & & & \\
Seed & & & & \\
Fertilizer N & $\mathrm{kg}$ & 70.0 & $\$ 0.55$ & $\$ 38.50$ \\
Herbicide & quarts ha & 50.0 & $\$ 0.81$ & $\$ 40.70$ \\
No-till Plant & 1 & 2.5 & $\$ 16.80$ & $\$ 42.00$ \\
Apply fertilizer & ha $^{-1}$ & 1.0 & $\$ 37.50$ & $\$ 37.50$ \\
Apply herbicide & ha $^{-1}$ & 1.0 & $\$ 12.50$ & $\$ 12.50$ \\
TOTAL ESTABLISHMENT COST & ha $^{-1}$ & 1.0 & $\$ 5.13$ & $\$ 5.13$ \\
INTEREST ON INVESTMENT & & & & $\$ 158.70$ \\
TOTAL VARIABLE COSTS/ha & & & $7.0 \%$ & $\$ 5.55$ \\
Net return over Variable Costs $\left(\$\right.$ ha $\left.^{-1}\right)$ & & & & -34.25 \\
Break-Even for Variable Costs $\left(\$\right.$ ton $\left.^{-1}\right)$ & & & -14.56 & \\
\hline
\end{tabular}


Appendix 3m: Economic returns from fall harvest of annual ryegrass-turnip mix established after glyphosate and received $100 \mathrm{~kg} \mathrm{ha}^{-1}$ of $\mathrm{N}$ on plots that had previously pearl millet in summer.

\begin{tabular}{|c|c|c|c|c|}
\hline Item & \multicolumn{4}{|c|}{ PRODUCTION } \\
\hline Yield & tons & 3.82 & $\$ 60.00$ & $\$ 228.96$ \\
\hline TOTAL CROP VALUE & & & & $\$ 228.96$ \\
\hline \multicolumn{5}{|c|}{ VARIABLE COSTS } \\
\hline ESTABLISHMENT COSTS & & & & \\
\hline Seed-Annual ryerass & $\mathrm{kg}$ & 50.0 & $\$ 1.76$ & $\$ 88.00$ \\
\hline -Turnip & $\mathrm{kg}$ & 3.4 & $\$ 17.49$ & $\$ 59.47$ \\
\hline Fertilizer $\mathrm{N}$ & $\mathrm{kg}$ & 100.0 & $\$ 0.81$ & $\$ 81.40$ \\
\hline Herbicide & ${ }_{1}^{\text {quarts ha }}$ & 2.5 & $\$ 16.80$ & $\$ 42.00$ \\
\hline No-till Plant & $\mathrm{ha}^{-1}$ & 1.0 & $\$ 37.50$ & $\$ 37.50$ \\
\hline Apply fertilizer & $\mathrm{ha}^{-1}$ & 1.0 & $\$ 12.50$ & $\$ 12.50$ \\
\hline Apply herbicide & $\mathrm{ha}^{-1}$ & 1.0 & $\$ 5.13$ & $\$ 5.13$ \\
\hline TOTAL ESTABLISHMENT COST & & & & $\$ 308.37$ \\
\hline INTEREST ON INVESTMENT & & & $7.0 \%$ & $\$ 10.79$ \\
\hline TOTAL VARIABLE COSTS/ha & & & & 319.16 \\
\hline Net return over Variable Costs $\left(\$ \mathrm{ha}^{-1}\right)$ & & & & -90.20 \\
\hline Break-Even for Variable Costs $\left(\$\right.$ ton $\left.^{-1}\right)$ & & & -23.64 & \\
\hline
\end{tabular}


Appendix $3 \mathrm{n}$ : Economic returns from fall harvest of triticale established after glyphosate and received $100 \mathrm{~kg} \mathrm{ha}^{-1}$ of $\mathrm{N}$ on plots that had previously pearl millet in summer.

\begin{tabular}{lcrrr}
\hline Item & $\begin{array}{c}\text { Units } \\
\text { PRODUCTION }\end{array}$ & Quantity & Value & $\$$ ha $^{-1}$ \\
\hline $\begin{array}{l}\text { Yield } \\
\text { TOTAL CROP VALUE }\end{array}$ & tons & 2.32 & $\$ 60.00$ & $\$ 139.20$ \\
& & & & $\$ 139.20$ \\
ESTABLISHMENT COSTS & VARIABLE COSTS & & & \\
Seed & & & & \\
Fertilizer N & $\mathrm{kg}$ & 70.0 & $\$ 0.55$ & $\$ 38.50$ \\
Herbicide & quarts ha & 100.0 & $\$ 0.81$ & $\$ 81.40$ \\
No-till Plant & 1 & 2.5 & $\$ 16.80$ & $\$ 42.00$ \\
Apply fertilizer & ha $^{-1}$ & 1.0 & $\$ 37.50$ & $\$ 37.50$ \\
Apply herbicide & ha $^{-1}$ & 1.0 & $\$ 12.50$ & $\$ 12.50$ \\
TOTAL ESTABLISHMENT COST & ha $^{-1}$ & 1.0 & $\$ 5.13$ & $\$ 5.13$ \\
INTEREST ON INVESTMENT & & & & $\$ 217.03$ \\
TOTAL VARIABLE COSTS/ha & & & $7.0 \%$ & $\$ 7.60$ \\
Net return over Variable Costs $\left(\$\right.$ ha $\left.^{-1}\right)$ & & & & -84.63 \\
Break-Even for Variable Costs $\left(\$\right.$ ton $\left.^{-1}\right)$ & & -36.82 & \\
\hline
\end{tabular}


Appendix 20: Economic returns from fall harvest of annual ryegrass-turnip mix established after burning and received $0 \mathrm{~kg} \mathrm{~N} \mathrm{ha}^{-1}$ on plots that had sudangrass in summer.

\begin{tabular}{|c|c|c|c|c|}
\hline Item & Units & Quantity & Value & $\$$ ha $^{-1}$ \\
\hline \multicolumn{5}{|c|}{ PRODUCTION } \\
\hline $\begin{array}{l}\text { Yield } \\
\text { TOTAL CROP VALUE }\end{array}$ & tons & 1.44 & & $\begin{array}{l}\$ 00.10 \\
\$ 86.10\end{array}$ \\
\hline \multirow{2}{*}{\multicolumn{5}{|c|}{ VARIABLE COSTS }} \\
\hline & & & & \\
\hline Seed-Annual ryerass & $\mathrm{kg}$ & 50.0 & $\$ 1.76$ & $\$ 88.00$ \\
\hline -Turnip & $\mathrm{kg}$ & 3.4 & $\$ 17.49$ & $\$ 59.47$ \\
\hline Fertilizer N & $\mathrm{kg}$ & 0.0 & $\$ 0.81$ & $\$ 0.00$ \\
\hline Propane & gal & 15.0 & $\$ 1.89$ & $\$ 28.35$ \\
\hline No-till Plant & $\mathrm{ha}^{-1}$ & 1.0 & $\$ 37.50$ & $\$ 37.50$ \\
\hline Apply Fertilizer & ha $^{-1}$ & 0.0 & $\$ 12.50$ & $\$ 0.00$ \\
\hline Apply burn & $\mathrm{ha}^{-1}$ & 1.0 & $\$ 21.43$ & $\$ 21.43$ \\
\hline TOTAL ESTABLISHMENT COST & & & & $\$ 213.32$ \\
\hline INTEREST ON INVESTMENT & & & $7.0 \%$ & $\$ 7.47$ \\
\hline TOTAL VARIABLE COSTS/ha & & & & 220.78 \\
\hline Net return over Variable Costs $\left(\$\right.$ ha $\left.^{-1}\right)$ & & & & -134.68 \\
\hline Break-Even for Variable Costs $\left(\$\right.$ ton $\left.^{-1}\right)$ & & & -93.86 & \\
\hline
\end{tabular}


Appendix 3p: Economic returns from fall harvest of triticale established after burning and received $0 \mathrm{~kg} \mathrm{~N} \mathrm{ha}^{-1}$ on plots that had previously sudangrass.

\begin{tabular}{|c|c|c|c|c|}
\hline Item & Units & Quantity & Value & $\$$ ha $^{-1}$ \\
\hline \multicolumn{5}{|c|}{ PRODUCTION } \\
\hline Yield & tons & 1.29 & $\$ 60.00$ & $\$ 77.16$ \\
\hline TOTAL CROP VALUE & & & & $\$ 77.16$ \\
\hline \multicolumn{5}{|c|}{ VARIABLE COSTS } \\
\hline ESTABLISHMENT COSTS & & & & \\
\hline Seed & $\mathrm{kg}$ & 70.0 & $\$ 0.55$ & $\$ 38.50$ \\
\hline Fertilizer $\mathrm{N}$ & $\mathrm{kg}$ & 0.0 & $\$ 0.81$ & $\$ 0.00$ \\
\hline Propane & gal & 15.0 & $\$ 1.89$ & $\$ 28.35$ \\
\hline No-till Plant & $\mathrm{ha}^{-1}$ & 1.0 & $\$ 37.50$ & $\$ 37.50$ \\
\hline Apply Fertilizer & $\mathrm{ha}^{-1}$ & 1.0 & $\$ 12.50$ & $\$ 12.50$ \\
\hline Apply burn & $\mathrm{ha}^{-1}$ & 1.0 & $\$ 21.43$ & $\$ 21.43$ \\
\hline TOTAL ESTABLISHMENT COST & & & & $\$ 138.28$ \\
\hline INTEREST ON INVESTMENT & & & $7.0 \%$ & $\$ 4.84$ \\
\hline TOTAL VARIABLE COSTS/ha & & & & 143.12 \\
\hline Net return over Variable Costs $\left(\$\right.$ ha $\left.^{-1}\right)$ & & & & -65.96 \\
\hline Break-Even for Variable Costs $\left(\$\right.$ ton $\left.^{-1}\right)$ & & & -51.29 & \\
\hline
\end{tabular}


Appendix 3q: Economic returns from fall harvest of annual ryegrass-turnip mix established after burning and received $50 \mathrm{~kg} \mathrm{~N} \mathrm{ha}^{-1}$ on plots that had previously sudangrass.

\begin{tabular}{|c|c|c|c|c|}
\hline Item & Units & Quantity & Value & $\$ h^{-1}$ \\
\hline \multicolumn{5}{|c|}{ PRODUCTION } \\
\hline Yield & tons & 2.26 & $\$ 60.00$ & $\$ 135.60$ \\
\hline TOTAL CROP VALUE & & & & $\$ 135.60$ \\
\hline \multicolumn{5}{|c|}{ VARIABLE COSTS } \\
\hline \multicolumn{5}{|l|}{ ESTABLISHMENT COSTS } \\
\hline Seed-Annual ryerass & $\mathrm{kg}$ & 50.0 & $\$ 1.76$ & $\$ 88.00$ \\
\hline -Turnip & $\mathrm{kg}$ & 3.4 & $\$ 17.49$ & $\$ 59.47$ \\
\hline Fertilizer $\mathrm{N}$ & $\mathrm{kg}$ & 50.0 & $\$ 0.81$ & $\$ 40.70$ \\
\hline Propane & gal & 15.0 & $\$ 1.89$ & $\$ 28.35$ \\
\hline No-till Plant & $\mathrm{ha}^{-1}$ & 1.0 & $\$ 37.50$ & $\$ 37.50$ \\
\hline Apply Fertilizer & $\mathrm{ha}^{-1}$ & 1.0 & $\$ 12.50$ & $\$ 12.50$ \\
\hline Apply burn & $\mathrm{ha}^{-1}$ & 1.0 & $\$ 21.43$ & $\$ 21.43$ \\
\hline TOTAL ESTABLISHMENT COST & & & & $\$ 287.95$ \\
\hline INTEREST ON INVESTMENT & & & $7.0 \%$ & $\$ 10.08$ \\
\hline TOTAL VARIABLE COSTS/ha & & & & 298.02 \\
\hline Net return over Variable Costs $\left(\$ \mathrm{ha}^{-1}\right)$ & & & & -162.42 \\
\hline Break-Even for Variable Costs $\left(\$\right.$ ton $\left.^{-1}\right)$ & & & -71.87 & \\
\hline
\end{tabular}


Appendix 3r: Economic returns from fall harvest of triticale established after burning and received $50 \mathrm{~kg} \mathrm{~N} \mathrm{ha}^{-1}$ on plots that had previously sudangrass.

\begin{tabular}{|c|c|c|c|c|}
\hline Item & Units & Quantity & Value & $\$$ ha $^{-1}$ \\
\hline \multicolumn{5}{|c|}{ PRODUCTION } \\
\hline Yield & tons & 2.04 & $\$ 60.00$ & $\$ 122.58$ \\
\hline TOTAL CROP VALUE & & & & $\$ 122.58$ \\
\hline \multicolumn{5}{|c|}{ VARIABLE COSTS } \\
\hline ESTABLISHMENT COSTS & & & & \\
\hline Seed & $\mathrm{kg}$ & 70.0 & $\$ 0.55$ & $\$ 38.50$ \\
\hline Fertilizer $\mathrm{N}$ & $\mathrm{kg}$ & 50.0 & $\$ 0.81$ & $\$ 40.70$ \\
\hline Propane & gal & 15.0 & $\$ 1.89$ & $\$ 28.35$ \\
\hline No-till Plant & $\mathrm{ha}^{-1}$ & 1.0 & $\$ 37.50$ & $\$ 37.50$ \\
\hline Apply Fertilizer & $\mathrm{ha}^{-1}$ & 1.0 & $\$ 12.50$ & $\$ 12.50$ \\
\hline Apply burn & $\mathrm{ha}^{-1}$ & 1.0 & $\$ 21.43$ & $\$ 21.43$ \\
\hline TOTAL ESTABLISHMENT COST & & & & $\$ 178.98$ \\
\hline INTEREST ON INVESTMENT & & & $7.0 \%$ & $\$ 6.26$ \\
\hline TOTAL VARIABLE COSTS/ha & & & & 185.24 \\
\hline Net return over Variable Costs $\left(\$\right.$ ha $\left.^{-1}\right)$ & & & & -62.66 \\
\hline Break-Even for Variable Costs $\left(\$\right.$ ton $\left.^{-1}\right)$ & & & -30.67 & \\
\hline
\end{tabular}


Appendix 2s: Economic returns from fall harvest of annual ryegrass-turnip mix established after burning and received $100 \mathrm{~kg} \mathrm{~N} \mathrm{ha}^{-1}$ on plots that had previously sudangrass.

\begin{tabular}{|c|c|c|c|c|}
\hline Item & Units & Quantity & Value & $\$ h^{-1}$ \\
\hline \multicolumn{5}{|c|}{ PRODUCTION } \\
\hline Yield & tons & 2.87 & $\$ 60.00$ & $\$ 171.90$ \\
\hline TOTAL CROP VALUE & & & & $\$ 171.90$ \\
\hline \multicolumn{5}{|c|}{ VARIABLE COSTS } \\
\hline ESTABLISHMENT COSTS & & & & \\
\hline Seed-Annual ryerass & $\mathrm{kg}$ & 50.0 & $\$ 1.76$ & $\$ 88.00$ \\
\hline -Turnip & $\mathrm{kg}$ & 3.4 & $\$ 17.49$ & $\$ 59.47$ \\
\hline Fertilizer $\mathrm{N}$ & $\mathrm{kg}$ & 100.0 & $\$ 0.81$ & $\$ 81.40$ \\
\hline Propane & gal & 15.0 & $\$ 1.89$ & $\$ 28.35$ \\
\hline No-till Plant & $\mathrm{ha}^{-1}$ & 1.0 & $\$ 37.50$ & $\$ 37.50$ \\
\hline Apply Fertilizer & $\mathrm{ha}^{-1}$ & 1.0 & $\$ 12.50$ & $\$ 12.50$ \\
\hline Apply burn & $\mathrm{ha}^{-1}$ & 1.0 & $\$ 21.43$ & $\$ 21.43$ \\
\hline TOTAL ESTABLISHMENT COST & & & & $\$ 328.65$ \\
\hline INTEREST ON INVESTMENT & & & $7.0 \%$ & $\$ 11.50$ \\
\hline TOTAL VARIABLE COSTS/ha & & & & 340.15 \\
\hline Net return over Variable Costs $\left(\$\right.$ ha $\left.^{-1}\right)$ & & & & -168.25 \\
\hline Break-Even for Variable Costs $\left(\$\right.$ ton $\left.^{-1}\right)$ & & & -58.73 & \\
\hline
\end{tabular}


Appendix 3t: Economic returns from fall harvest of triticale established after burning and received $100 \mathrm{~kg} \mathrm{~N} \mathrm{ha}^{-1}$ on plots that had previously sudangrass.

\begin{tabular}{|c|c|c|c|c|}
\hline Item & Units & Quantity & Value & $\$$ ha $^{-1}$ \\
\hline & \multicolumn{4}{|c|}{ PRODUCTION } \\
\hline $\begin{array}{l}\text { Yield } \\
\text { TOTAL CROP VALUE }\end{array}$ & tons & 2.35 & $\$ 60.00$ & $\begin{array}{l}\$ 140.76 \\
\$ 140.76\end{array}$ \\
\hline \multicolumn{5}{|c|}{ VARIABLE COSTS } \\
\hline ESTABLISHMENT COSTS & & & & \\
\hline Seed & $\mathrm{kg}$ & 70.0 & $\$ 0.55$ & $\$ 38.50$ \\
\hline Fertilizer $\mathrm{N}$ & $\mathrm{kg}$ & 100.0 & $\$ 0.81$ & $\$ 81.40$ \\
\hline Propane & gal & 15.0 & $\$ 1.89$ & $\$ 28.35$ \\
\hline No-till Plant & $\mathrm{ha}^{-1}$ & 1.0 & $\$ 37.50$ & $\$ 37.50$ \\
\hline Apply Fertilizer & $\mathrm{ha}^{-1}$ & 1.0 & $\$ 12.50$ & $\$ 12.50$ \\
\hline Apply burn & $\mathrm{ha}^{-1}$ & 1.0 & $\$ 21.43$ & $\$ 21.43$ \\
\hline TOTAL ESTABLISHMENT COST & & & & $\$ 219.68$ \\
\hline INTEREST ON INVESTMENT & & & $7.0 \%$ & $\$ 7.69$ \\
\hline TOTAL VARIABLE COSTS/ha & & & & 227.37 \\
\hline Net return over Variable Costs $\left(\$\right.$ ha $\left.^{-1}\right)$ & & & & -86.61 \\
\hline Break-Even for Variable Costs $\left(\$\right.$ ton $\left.^{-1}\right)$ & & & -36.92 & \\
\hline
\end{tabular}


Appendix 3u: Economic returns from fall harvest of annual ryegrass-turnip mix established after glyphosate and received $0 \mathrm{~kg} \mathrm{~N}^{-1}$ on plots that had

previously sudangrass.

\begin{tabular}{lcrrr}
\hline Item & $\begin{array}{c}\text { Units } \\
\text { PRODUCTION }\end{array}$ & Quantity & Value & $\$$ ha $^{-1}$ \\
\hline $\begin{array}{l}\text { Yield } \\
\text { TOTAL CROP VALUE }\end{array}$ & tons & 1.98 & $\$ 60.00$ & $\$ 118.86$ \\
& & & & $\$ 118.86$ \\
ESTABLISHMENT COSTS & VARIABLE COSTS & & & \\
Seed-Annual ryerass & & & & \\
$\quad-$ Turnip & $\mathrm{kg}$ & 50.0 & $\$ 1.76$ & $\$ 88.00$ \\
Fertilizer N & $\mathrm{kg}$ & 3.4 & $\$ 17.49$ & $\$ 59.47$ \\
Herbicide & quarts ha & 0.0 & $\$ 0.81$ & $\$ 0.00$ \\
No-till Plant & 1 & 2.5 & $\$ 16.80$ & $\$ 42.00$ \\
Apply fertilizer & ha $^{-1}$ & 1.0 & $\$ 37.50$ & $\$ 37.50$ \\
Apply herbicide & ha $^{-1}$ & 1.0 & $\$ 12.50$ & $\$ 12.50$ \\
TOTAL ESTABLISHMENT COST & ha $^{-1}$ & 1.0 & $\$ 5.13$ & $\$ 5.13$ \\
INTEREST ON INVESTMENT & & & & $\$ 244.60$ \\
TOTAL VARIABLE COSTS/ha & & & $7.0 \%$ & $\$ 8.56$ \\
Net return over Variable Costs $\left(\$\right.$ ha $\left.^{-1}\right)$ & & & & 253.16 \\
Break-Even for Variable Costs $\left(\$\right.$ ton $\left.^{-1}\right)$ & & & -134.30 \\
\hline
\end{tabular}


Appendix 3v: Economic returns from fall harvest of triticale established after glyphosate and received $0 \mathrm{~kg} \mathrm{~N} \mathrm{ha}^{-1}$ on plots that had previously sudangrass.

\begin{tabular}{|c|c|c|c|c|}
\hline Item & $\begin{array}{l}\text { Units } \\
\text { ION }\end{array}$ & Quantity & Value & $\$ h^{-1}$ \\
\hline Yield & tons & 1.22 & $\$ 60.00$ & $\$ 73.02$ \\
\hline TOTAL CROP VALUE & & & & $\$ 73.02$ \\
\hline \multicolumn{5}{|c|}{ VARIABLE COSTS } \\
\hline ESTABLISHMENT COSTS & & & & \\
\hline Seed & $\mathrm{kg}$ & 70.0 & $\$ 0.55$ & $\$ 38.50$ \\
\hline Fertilizer $\mathrm{N}$ & $\mathrm{kg}$ & 0.0 & $\$ 0.81$ & $\$ 0.00$ \\
\hline Herbicide & ${ }_{1}^{\text {quarts ha }}$ & 2.5 & $\$ 16.80$ & $\$ 42.00$ \\
\hline No-till Plant & $\mathrm{ha}^{-1}$ & 1.0 & $\$ 37.50$ & $\$ 37.50$ \\
\hline Apply fertilizer & $\mathrm{ha}^{-1}$ & 1.0 & $\$ 12.50$ & $\$ 12.50$ \\
\hline Apply herbicide & $\mathrm{ha}^{-1}$ & 1.0 & $\$ 5.13$ & $\$ 5.13$ \\
\hline TOTAL ESTABLISHMENT COST & & & & $\$ 135.63$ \\
\hline INTEREST ON INVESTMENT & & & $7.0 \%$ & $\$ 4.75$ \\
\hline TOTAL VARIABLE COSTS/ha & & & & 140.38 \\
\hline Net return over Variable Costs $\left(\$\right.$ ha $\left.^{-1}\right)$ & & & & -67.36 \\
\hline Break-Even for Variable Costs $\left(\$\right.$ ton $\left.^{-1}\right)$ & & & -55.35 & \\
\hline
\end{tabular}


Appendix 3u: Economic returns from fall harvest of annual ryegrass-turnip mix established after burning and received $100 \mathrm{~kg} \mathrm{~N} \mathrm{ha}^{-1}$ on plots that had previously sudangrass.

\begin{tabular}{lcrrr}
\hline Item & $\begin{array}{c}\text { Units } \\
\text { PRODUCTION }\end{array}$ & Quantity & Value & $\$$ ha $^{-1}$ \\
\hline $\begin{array}{l}\text { Yield } \\
\text { TOTAL CROP VALUE }\end{array}$ & tons & 2.29 & $\$ 60.00$ & $\$ 137.40$ \\
& & & & $\$ 137.40$ \\
ESTABLISHMENT COSTS & VARIABLE COSTS & & & \\
Seed-Annual ryerass & & & & \\
$\quad$-Turnip & $\mathrm{kg}$ & 50.0 & $\$ 1.76$ & $\$ 88.00$ \\
Fertilizer N & $\mathrm{kg}$ & 3.4 & $\$ 17.49$ & $\$ 59.47$ \\
Herbicide & $\mathrm{kg}$ & 50.0 & $\$ 0.81$ & $\$ 40.70$ \\
No-till Plant & quarts ha & 2.5 & $\$ 16.80$ & $\$ 42.00$ \\
Apply fertilizer & ha $^{-1}$ & 1.0 & $\$ 37.50$ & $\$ 37.50$ \\
Apply herbicide & ha $^{-1}$ & 1.0 & $\$ 12.50$ & $\$ 12.50$ \\
TOTAL ESTABLISHMENT COST & ha $^{-1}$ & 1.0 & $\$ 5.13$ & $\$ 5.13$ \\
INTEREST ON INVESTMENT & & & & $\$ 285.30$ \\
TOTAL VARIABLE COSTS/ha & & & $7.0 \%$ & $\$ 9.99$ \\
Net return over Variable Costs $\left(\$\right.$ ha $^{-1}$ ) & & & & 295.28 \\
Break-Even for Variable Costs $\left(\$\right.$ ton $\left.^{-1}\right)$ & & & -157.88 \\
\hline
\end{tabular}


Appendix 3w: Economic returns from fall harvest of triticale established after burning and received $50 \mathrm{~kg} \mathrm{~N} \mathrm{ha}^{-1}$ on plots that had previously sudangrass.

\begin{tabular}{lcrrr}
\hline Item & $\begin{array}{c}\text { Units } \\
\text { PRODUCTION }\end{array}$ & Quantity & Value & $\$$ ha $^{-1}$ \\
\hline $\begin{array}{l}\text { Yield } \\
\text { TOTAL CROP VALUE }\end{array}$ & tons & 1.73 & $\$ 60.00$ & $\$ 103.80$ \\
& & & & $\$ 103.80$ \\
ESTABLISHMENT COSTS & VARIABLE COSTS & & & \\
Seed & & & & \\
Fertilizer N & $\mathrm{kg}$ & 70.0 & $\$ 0.55$ & $\$ 38.50$ \\
Herbicide & quarts ha & 50.0 & $\$ 0.81$ & $\$ 40.70$ \\
No-till Plant & 1 & 2.5 & $\$ 16.80$ & $\$ 42.00$ \\
Apply fertilizer & ha $^{-1}$ & 1.0 & $\$ 37.50$ & $\$ 37.50$ \\
Apply herbicide & ha $^{-1}$ & 1.0 & $\$ 12.50$ & $\$ 12.50$ \\
TOTAL ESTABLISHMENT COST & ha $^{-1}$ & 1.0 & $\$ 5.13$ & $\$ 5.13$ \\
INTEREST ON INVESTMENT & & & & $\$ 176.33$ \\
TOTAL VARIABLE COSTS/ha & & & $7.0 \%$ & $\$ 6.17$ \\
Net return over Variable Costs $\left(\$\right.$ ha $\left.^{-1}\right)$ & & & & 182.50 \\
Break-Even for Variable Costs $\left(\$\right.$ ton $\left.^{-1}\right)$ & & -45.49 & \\
\hline
\end{tabular}


Appendix 3x: Economic returns from fall harvest of annual ryegrass-turnip mix established after glyphosate and received $100 \mathrm{~kg} \mathrm{~N} \mathrm{ha}^{-1}$ on plots that had previously sudangrass.

\begin{tabular}{|c|c|c|c|c|}
\hline Item & $\begin{array}{l}\text { Units } \\
\text { rION }\end{array}$ & Quantity & Value & $\$ \mathrm{ha}^{-1}$ \\
\hline Yield & tons & 3.16 & $\$ 60.00$ & $\$ 189.60$ \\
\hline \multicolumn{5}{|c|}{ VARIABLE COSTS } \\
\hline ESTABLISHMENT COSTS & & & & \\
\hline Seed-Annual ryerass & $\mathrm{kg}$ & 50.0 & $\$ 1.76$ & $\$ 88.00$ \\
\hline -Turnip & $\mathrm{kg}$ & 3.4 & $\$ 17.49$ & $\$ 59.47$ \\
\hline Fertilizer $\mathrm{N}$ & $\mathrm{kg}$ & 100.0 & $\$ 0.81$ & $\$ 81.40$ \\
\hline Herbicide & ${ }_{1}^{\text {quarts ha }}$ & 2.5 & $\$ 16.80$ & $\$ 42.00$ \\
\hline No-till Plant & $\mathrm{ha}^{-1}$ & 1.0 & $\$ 37.50$ & $\$ 37.50$ \\
\hline Apply fertilizer & $\mathrm{ha}^{-1}$ & 1.0 & $\$ 12.50$ & $\$ 12.50$ \\
\hline Apply herbicide & $\mathrm{ha}^{-1}$ & 1.0 & $\$ 5.13$ & $\$ 5.13$ \\
\hline TOTAL ESTABLISHMENT COST & & & & $\$ 326.00$ \\
\hline INTEREST ON INVESTMENT & & & $7.0 \%$ & $\$ 11.41$ \\
\hline TOTAL VARIABLE COSTS/ha & & & & 337.41 \\
\hline Net return over Variable Costs $\left(\$ \mathrm{ha}^{-1}\right)$ & & & & -147.81 \\
\hline Break-Even for Variable Costs $\left(\$\right.$ ton $\left.^{-1}\right)$ & & & -46.77 & \\
\hline
\end{tabular}


Appendix 3y: Economic returns from fall harvest of triticale established after glyphosate and received $100 \mathrm{~kg} \mathrm{~N} \mathrm{ha}^{-1}$ on plots that had previously sudangrass.

\begin{tabular}{|c|c|c|c|c|}
\hline Item & \multicolumn{3}{|c|}{ PRODUCTION } & $\$ \mathrm{ha}^{-1}$ \\
\hline Yield & tons & 2.23 & $\$ 60.00$ & $\$ 133.80$ \\
\hline TOTAL CROP VALUE & & & & $\$ 133.80$ \\
\hline \multicolumn{5}{|c|}{ VARIABLE COSTS } \\
\hline ESTABLISHMENT COSTS & & & & \\
\hline Seed & $\mathrm{kg}$ & 70.0 & $\$ 0.55$ & $\$ 38.50$ \\
\hline Fertilizer $\mathrm{N}$ & $\mathrm{kg}$ & 100.0 & $\$ 0.81$ & $\$ 81.40$ \\
\hline Herbicide & ${ }_{1}^{\text {quarts ha }}$ & 2.5 & $\$ 16.80$ & $\$ 42.00$ \\
\hline No-till Plant & $\mathrm{ha}^{-1}$ & 1.0 & $\$ 37.50$ & $\$ 37.50$ \\
\hline Apply fertilizer & $\mathrm{ha}^{-1}$ & 1.0 & $\$ 12.50$ & $\$ 12.50$ \\
\hline Apply herbicide & $\mathrm{ha}^{-1}$ & 1.0 & $\$ 5.13$ & $\$ 5.13$ \\
\hline TOTAL ESTABLISHMENT COST & & & & $\$ 217.03$ \\
\hline INTEREST ON INVESTMENT & & & $7.0 \%$ & $\$ 7.60$ \\
\hline TOTAL VARIABLE COSTS/ha & & & & 224.63 \\
\hline Net return over Variable Costs $\left(\$\right.$ ha $\left.^{-1}\right)$ & & & & -90.83 \\
\hline Break-Even for Variable Costs $\left(\$\right.$ ton $\left.^{-1}\right)$ & & & -40.73 & \\
\hline
\end{tabular}




\section{VITA}

Name

Birth place

Date of birth

Parents

Wife....

Children
Evans Abenga Basweti

Nyamira, Kenya

December $21^{\text {st }}, 1960$

Benson and Priscilla Basweti (Both deceased)

Elizabeth Abenga

Elvis and Ernest Abenga

\section{Institutions attended:}

Etono Primary School, Nyamira, Kenya

1971-1976

Kiabonyoru Secondary School, Nyamira, Kenya

1977-1980

Kisumu Technical High School, Kisumu, Kenya

1981-1982

Egerton University, Nakuru, Kenya

1987-1990

Egerton University, Nakuru, Kenya

1994-1996

Moi university, Eldoret, Kenya

1997-2000

\section{Degree Awarded}

Dipl. Animal Husbandry, Egerton University

1990

BS in Animal Production, Egerton University

1996

MPh. Forestry (Agroforestry), Moi University

2000

\section{Employment: Ministry of livestock Production and Fisheries}

